\title{
Medicinal plants for prevention and treatment of cardiovascular diseases - A review
}

\author{
Prof Dr Ali Esmail Al-Snafi \\ Department of Pharmacology, College of Medicine, Thi qar University, Iraq.
}

\begin{abstract}
There were substantial evidences that many medicinal plants decreased the risk of cardiovascular diseases. With the high prevalence of herbal medicine use worldwide, the information regarding the therapeutic use or safety of herbal remedies usually obtained from books and pamphlets, most of which base their information on traditional reputation rather than relying on existing scientific research. This review will cover the plants with vascular, hypotensive, cardiac, cardioprotective, antiarrhythmic, hypolipidemic, hemostatic, fibrinolytic and anticoagulant effects.
\end{abstract}

Keywords: medicinal plants, cardioprotective, antiarrhythmic, hypolipidemic, hemostatic, fibrinolytic, anticoagulant

\section{I . INTRODUCTION:}

There were substantial evidences that many medicinal plants decreased the risk of cardiovascular diseases. Previous reviews revealed that many medicinal plants affected cardiovascular function and can be utilize for therapeutic purposes. They produced wide range of cardiovascular effects included vascular, hypotensive, positive and negative inotropic, cardioprotective, antiarrhythmic, hypolipidemic, hemostatic, fibrinolytic and anticoagulant effects [1-2]. This review was designed to cover the cardiovascular effects of medicinal plants.

Plants with vascular and hypotensive effects:

\begin{tabular}{|c|c|c|c|}
\hline Plant & The tested constituent & Activity & Ref \\
\hline Adonis vernalis & $\begin{array}{l}\text { tincture of Adonis } \\
\text { vernalis }\end{array}$ & $\begin{array}{l}\text { Tincture of Adonis vernalis was evaluated as hypotensive } \\
\text { therapy. The dog blood pressure responses was varied with dose, } \\
\text { low doses showed rise in blood pressure whereas larger doses } \\
\text { showed fall in blood pressure. }\end{array}$ & 4 \\
\hline Agrimonia eupatoria & different extracts & $\begin{array}{l}\text { A hypotensive effect in anaesthetised cats has been documented } \\
\text { for an agrimony extracts given by intravenous injection; blood } \\
\text { pressure was lowered by more than } 40 \% \text {. }\end{array}$ & $5-6$ \\
\hline Allium sativum & raw and extracts & $\begin{array}{l}\text { Experimental and clinical studies showed that garlic produced } \\
\text { hypotensive effects. Garlic induced significant reduction in } \\
\text { systolic and diastolic blood pressure. }\end{array}$ & $7-12$ \\
\hline Althaea rosea & alcoholic extract & $\begin{array}{l}\text { The alcoholic extract showed a transient hypotensive effect on } \\
\text { anesthetic cats. }\end{array}$ & 13 \\
\hline \multirow[t]{4}{*}{ Ammi visnaga } & $\begin{array}{l}\text { visnadine } \quad \text { and } \\
\text { visnagin }\end{array}$ & $\begin{array}{l}\text { Visnadine caused nonspecific inhibition of vascular smooth } \\
\text { muscle. It was selectively inhibited the contractile response in } \\
\text { the rat isolated aortic ring and portal vein segment. On the other } \\
\text { hand ,intravenous administration of visnagin decreased blood } \\
\text { pressure with no significant changes on the heart rate. }\end{array}$ & $14-16$ \\
\hline & $\begin{array}{l}\text { chloroform, and } \\
\text { methanol extract }\end{array}$ & $\begin{array}{l}\text { A chloroform, and methanol extract }(1 \mathrm{mg} / \mathrm{ml}) \text { of the fruits } \\
\text { inhibited the potassium chloride induced contractions of the } \\
\text { rabbit guinea-pig aorta in vitro. }\end{array}$ & $17-18$ \\
\hline & visnadin & $\begin{array}{l}\text { Visnadin, } 60.0 \mu \mathrm{g} / \mathrm{ml} \text { or } 120.0 \mu \mathrm{g} / \mathrm{ml} \text {, increased coronary blood } \\
\text { flow in isolated guinea-pig hearts by } 46 \% \text { and } 57 \% \text { respectively. }\end{array}$ & $19-20$ \\
\hline & visnadin & $\begin{array}{l}\text { Visnagin inhibited the contractile responses induced in rat aortic } \\
\text { rings by: (a) } \mathrm{KCl} \text { or increases of extracellullar } \mathrm{Ca}^{2+} \text { in } \mathrm{KCl} \\
\text { depolarized aortic rings, its effects being more potent against low } \\
(20 \mathrm{mM}) \text { than high }(80 \mathrm{mM}) \mathrm{KCl} \text {-induced contractions, (b) } \\
\text { noradrenaline in } \mathrm{Ca}^{2+} \text {-containing solution and less effectively } \\
\text { those in } \mathrm{Ca}^{2+} \text {-free solution and (c) phorbol } 12 \text {-myristate } 13- \\
\text { acetate }(\mathrm{PMA}) \text { in a } \mathrm{Ca}^{2+} \text {-containing and with a lower potency in } \\
\mathrm{Ca}^{2+} \text {-free medium. The relaxation induced by visnagin in aorta } \\
\text { precontracted with noradrenaline was not affected by } \\
\text { endothelium removal. Additionally, visnagin inhibited the }\end{array}$ & 21 \\
\hline
\end{tabular}




\begin{tabular}{|c|c|c|c|}
\hline & & $\begin{array}{l}\text { spontaneous myogenic contractions of portal veins. The results } \\
\text { showed that visnagin inhibited vascular smooth muscle } \\
\text { contractility by acting at multiple sites. }\end{array}$ & \\
\hline & khellin & $\begin{array}{l}\text { Khella seems to improve blood supply to smooth muscles and } \\
\text { makes myocardial metabolism more efficient. It dilated the } \\
\text { coronary vessels, and increased the capacity of the heart without } \\
\text { increasing the heart rate. }\end{array}$ & 22 \\
\hline Anethum graveolens & seed oil & $\begin{array}{l}\text { Intravenous administration of } 5-10 \mathrm{mg} / \mathrm{kg} \text { body weight of } 5 \% \\
\text { seed oil in saline to cats caused hypotension and increased } \\
\text { respiration volume. }\end{array}$ & $23-25$ \\
\hline Apium graveolens & $\begin{array}{l}\text { aqueous and ethanol } \\
\text { extracts }\end{array}$ & $\begin{array}{l}\text { The effects of aqueous and ethanol extracts }(0.5-15 \mathrm{mg} / \mathrm{kg}) \text { was } \\
\text { investigated on the mean blood pressure of anaesthetized rabbits } \\
\text { and contractility of isolated atria of the rats. The intravenous } \\
\text { administration of aqueous extracts induced the least hypotensive } \\
\text { effects }(14.35 \pm 2.94 \%) \text {, while the ethanol extract caused the } \\
\text { greatest fall in the blood pressure }(45.79 \pm 10.86 \%) \text {. Hypotensive } \\
\text { effect of the extracts was partially blocked by atropine }(0.3 \\
\mathrm{mg} / \mathrm{kg}) \text {. }\end{array}$ & 26 \\
\hline Arachis hypogaea & $\begin{array}{l}\text { peptides isolated from } \\
\text { peanut }\end{array}$ & $\begin{array}{l}\text { A bioactive peptides with antihypertensive effects against } \\
\text { Angiotensin Converting Enzyme were isolated from peanut. }\end{array}$ & 27 \\
\hline \multirow[t]{2}{*}{ Avena sativa } & fibers of oats & $\begin{array}{l}\text { In addition to cholesterol lowering effect of Avena sativa, it } \\
\text { improved the blood pressure when consumed with vitamin C, } \\
\text { improved endothelial function, and exerted angiotensine } \\
\text { converting enzyme inhibition. According to these results, the } \\
\text { United States Food and Drug Administration in } 1997 \text { approved } \\
\text { the heart-health benefit of food containing soluble fiber from } \\
\text { oats. }\end{array}$ & $28-30$ \\
\hline & beta glucan from oats & $\begin{array}{l}\text { In overweight patients, beta glucan from oats has been shown to } \\
\text { decrease hypertension. Avenanthramide is an oat polyphenol that } \\
\text { has been shown to enhance production of nitric oxide, a potent } \\
\text { vasodilator, and to inhibit thickening of vascular smooth muscle. } \\
\text { Both actions are preventative to developing atherosclerosis. }\end{array}$ & $31-32$ \\
\hline Bryophyllum calycinum & $\begin{array}{ll}\text { aqueous } & \text { and } \\
\text { methanolic } & \text { leaf } \\
\text { extracts } & \end{array}$ & $\begin{array}{l}\text { The effects of aqueous and methanolic leaf extracts of the herb } \\
\text { were examined on arterial blood pressures and heart rates of } \\
\text { normal (normotensive) and spontaneously hypertensive rats, } \\
\text { using invasive and non-invasive techniques. Both the aqueous } \\
\text { and methanolic leaf extracts of the plant }(50-800 \mathrm{mg} / \mathrm{kg} \text { iv or ip) } \\
\text { produced dose-related, significant ( } \mathrm{P}<0.05-0.001) \mathrm{decreases} \text { in } \\
\text { arterial blood pressures and heart rates of anaesthetized } \\
\text { normotensive and hypertensive rats. The hypotensive effects of } \\
\text { the leaf extracts were more pronounced in the hypertensive than } \\
\text { in normotensive rats. The leaf extracts }(0.25-5.0 \mathrm{mg} / \mathrm{ml}) \text { also } \\
\text { inhibited provoked electrical field stimulation (ES-provoked), as } \\
\text { well as potassium and receptor-mediated agonist drugs-induced } \\
\text { contractions of the rat isolated thoraxic aortic strips in a non- } \\
\text { specific manner. }\end{array}$ & $33-35$ \\
\hline Caesalpinia crista & aqueous leaf extract & $\begin{array}{l}\text { The administration of aqueous leaf extract induced a progressive } \\
\text { decrease of blood pressure. The hypotensive action of the extract } \\
\text { was dose-dependent and reversible. Hypotension induced by } \\
\text { aqueous leaf extract of Caesalpinia crista or acetylcholine were } \\
\text { inhibited by atropine. On the other hand, it significantly reduced } \\
\text { blood pressure caused by the prior administration of adrenaline. }\end{array}$ & $36-37$ \\
\hline \multirow[t]{2}{*}{ Capparis spinosa } & aqueous extract & $\begin{array}{l}\text { The vaso relaxant effect of Capparis spinosa aqueous extract } \\
\text { (CSAE) at a dose of } 10 \mathrm{mg} / \mathrm{ml} \text { was studied on the isolated aortic } \\
\text { rings of normal rats. Adding of CSAE during the plateau phase } \\
\text { of contraction, induced by noradrenaline and } \mathrm{KCl} \text {, produced a } \\
\text { rapid relaxation. Incubation of aortic ring with CSAE during } 30 \\
\text { min shifted the noradrenaline induced dose response curve } \\
(\mathrm{p}<0.001 \text { ), the maximum response }(\mathrm{p}<0.001) \text { was attenuated } \\
\text { which indicating that antagonistic effect of the } \alpha 1- \\
\text { adrenoreceptors was non-competitive. However, endothelium } \\
\text { remove significantly reduced the vaso relaxant effect of CSAE } \\
\text { (p<0.01). Furthermore, nitric oxide inhibition reduced the vaso } \\
\text { relaxant effect of CSAE. }\end{array}$ & 38 \\
\hline & $\begin{array}{l}\text { aqueous extract of } \\
\text { roots, leaves, stems, } \\
\text { flowers, fruits and } \\
\text { kernels }\end{array}$ & $\begin{array}{l}\text { The in vitro vasomotor effects of aqueous extract of of roots, } \\
\text { leaves, stems, flowers, fruits and kernels were evaluated on the } \\
\text { rings of thoracic aorta and windpipe of rat. The addition of } \\
\text { extracts with different concentrations during the stage of } \\
\text { contraction led by the phenylephrin for the thoracic arteries } \\
\text { showed a light vasodilatation. Furthermore } 30 \text { min incubation } \\
\text { with extracts at different concentrations showed a significant } \\
\text { vasodilator effect for fruits and kernels, and vasoconstrictor } \\
\text { effect for leaves. }\end{array}$ & 39 \\
\hline
\end{tabular}




\begin{tabular}{|c|c|c|c|}
\hline \multirow[t]{4}{*}{ Carthamus tinctorius } & safflower yellow & $\begin{array}{l}\text { Safflower yellow (SY) } 1-2 \mathrm{~g} / \mathrm{kg} / \text { day lowered the blood pressure } \\
\text { of spontaneously hypertensive rats (SHR), for about } 1.86-3.86 \\
\mathrm{kPa} \text {. Five weeks after administration of SY, the plasma renin } \\
\text { activity and angiotensin II level diminished in the SHR } \\
\text { experimental groups, which indicated that the decrease of blood } \\
\text { pressure is mediated by inactivation of renin-angiotensin system. }\end{array}$ & $\begin{array}{l}40 \\
.\end{array}$ \\
\hline & $\begin{array}{l}\text { hydroxysafflor yellow } \\
\text { A }\end{array}$ & $\begin{array}{l}\text { The vasodilatation effects of hydroxysafflor yellow A (HSYA) } \\
\text { on pulmonary artery (PA) were explored by an assay of tension } \\
\text { study on rat pulmonary artery (PA) rings. Results suggest that } \\
\text { HSYA possessed vascular relaxation effects on rat PA by } \\
\text { activating the KV channel in pulmonary vascular smooth muscle } \\
\text { cells (PVSMCs). }\end{array}$ & 41 \\
\hline & $\begin{array}{l}\text { hydroxysafflor yellow } \\
\text { A }\end{array}$ & $\begin{array}{l}\text { Intravenous injection of the hydroxysafflor yellow A (HSYA) } \\
\text { reduced left ventricular systolic pressure (LVSP), left ventricular } \\
\text { end-diastolic pressure (LVEDP), the maximum rate of increase } \\
\text { of left ventricular pressure (+dp/dt(max)) and heart rate (HR) in a } \\
\text { dose-dependent manner. HSYA had no remarkable effect on the } \\
\text { maximum rate of decrease of left ventricular pressure (- } \\
\text { dp/dt(max)); BK(Ca) and K(ATP) blocker can weakened the } \\
\text { inhibitory effect of HSYA on heart function and HR, but K(V) } \\
\text { and K(ACh) blocker did not significantly weaken the HSYA } \\
\text { effects. }\end{array}$ & 42 \\
\hline & $\begin{array}{l}\mathrm{N} \text {-(p-coumaroyl) } \\
\text { serotonin }(\mathrm{CS}) \text { and } \mathrm{N} \text { - } \\
\text { feruloyl serotonin } \\
(\mathrm{FS})\end{array}$ & $\begin{array}{l}\text { The vascular effect of } \mathrm{N} \text {-(p-coumaroyl) serotonin (CS) and } \mathrm{N}- \\
\text { feruloylserotonin (FS), was evaluated. Both CS and FS (each } 10 \\
\text { to } 100 \mu \mathrm{M} \text { ) relaxed rat femoral arteries, which were pre- } \\
\text { contracted by } 10-5 \mathrm{M} \text { phenylephrine or } 50 \mathrm{mM} \mathrm{KCl} \text {, } \\
\text { independently of their endothelium. Both CS and FS also } \\
\text { concentration-dependently inhibited the increase of cytosolic free } \\
\mathrm{Ca} 2+\text { concentration that was induced by KCl or 5- } \\
\text { hydroxytryptamine in cultured rat vascular smooth muscle cells } \\
\text { (VSMCs). }\end{array}$ & 43 \\
\hline Chamaemelum nobile & aqueous extract & $\begin{array}{l}\text { Single oral administration of } C \text {. nobile aqueous extract (CNAE) } \\
(140 \mathrm{mg} / \mathrm{kg} \text { ) produced a significant reduction }(\mathrm{p}<0.05) \text { in } \\
\text { systolic blood pressure (SBP) after } 24 \mathrm{~h} \text { of the administration. } \\
\text { Daily oral administration of CNAE }(140 \mathrm{mg} / \mathrm{kg}) \text { during } 3 \text { weeks } \\
\text { produced a significant reduction in SBP in the day } 8(\mathrm{p}<0.01) \text { of } \\
\text { treatment. Furthermore, CNAE produced a significant increase in } \\
\text { urinary output and electrolytes excretion }(\mathrm{p}<0.01) \text { from the day } \\
8 \text { to the end of treatment. The in vitro vasorelaxant effect of } C \text {. } \\
\text { nobile aqueous extract was evaluated using aortic ring isolated } \\
\text { from Wistar rats. } C \text {. nobile aqueous extract at doses of } 5,10 \text { and } \\
20 \mathrm{mg} / \mathrm{mlpossessed} \mathrm{in} \mathrm{vitro} \mathrm{vasorelaxant} \mathrm{effect.} \mathrm{Incubation} \mathrm{of} \\
\text { aqueous } C \text {. nobile extract for } 30 \text { minutes produced a significant } \\
\text { shift of the dose-response curve to norepinephrine (NE) }(10-8 \text { to } \\
10-5) \mathrm{M}(\mathrm{p}<0.001) \text {. }\end{array}$ & 44 \\
\hline Cicer arietinum & $\begin{array}{l}\text { legumin of Cicer } \\
\text { arietinum and the } \\
\text { fractions of } \\
\text { hydrolysate }\end{array}$ & $\begin{array}{l}\text { Treatment of legumin of Cicer arietinum with alcalase yielded a } \\
\text { hydrolysate that inhibited the angiotensin I converting enzyme } \\
\text { with an IC } 50 \text { of } 0.18 \mathrm{mg} / \mathrm{ml} \text {. Fractionation of this hydrolysate by } \\
\text { reverse phase chromatography afforded six inhibitory peptides } \\
\text { with IC } 50 \text { values ranging from } 0.011 \text { to } 0.021 \mathrm{mg} / \mathrm{ml} \text {. All these } \\
\text { peptides contain the amino acid methionine and are also rich in } \\
\text { other hydrophobic amino acids. Hydrolysates of chickpea } \\
\text { legumin obtained by treatment with alcalase are a good source of } \\
\text { peptides with angiotensin-1 converting enzyme inhibitory } \\
\text { activity. }\end{array}$ & $45-46$ \\
\hline Cichorium intybus & $\begin{array}{l}\text { chicoric acid and } \\
\text { caffeic acid }\end{array}$ & $\begin{array}{l}\text { The vasorelaxant activities of chicoric acid from Cichorium } \\
\text { intybus along with caffeic acid were studied in isolated rat aorta } \\
\text { strips. chicoric acid, a diester composed of (S,S)-tartaric acid } \\
\text { and caffeic acid, showed slow relaxation activity against } \\
\text { norepinephrine (NE)-induced contraction of rat aorta } \\
\text { with/without endothelium. These compound did not affect } \\
\text { contraction induced by a high concentration of potassium ( } 60 \\
\mathrm{mM} \mathrm{K+),} \mathrm{while} \mathrm{it} \mathrm{inhibited} \mathrm{NE-induced} \mathrm{vasocontraction} \mathrm{in} \mathrm{the} \\
\text { presence of nicardipine. The results revealed that the inhibition } \\
\text { of NE-induced vasocontraction is due to a decrease in calcium } \\
\text { influx from the extracellular space, which enhanced by NE. }\end{array}$ & 47 \\
\hline Cistanche tubulosa & $\begin{array}{l}\text { echinacoside, a } \\
\text { phenylethanoid } \\
\text { glycoside isolated } \\
\text { from } \\
\text { tubulosa }\end{array}$ & $\begin{array}{l}\text { The vasorelaxant activity of echinacoside, a phenylethanoid } \\
\text { glycoside isolated from Cistanche tubulosa, and its possible } \\
\text { underlying mechanism on isolated rat thoracic aortic rings pre- } \\
\text { contracted with phenylephrine (PE, } 1 \text { microM) and } \mathrm{KCl}(60 \mathrm{mM}) \\
\text { was investigated. Echinacoside ( } 30-300 \text { microM) exhibited an } \\
\text { acute relaxation in endothelium-intact rings in a concentration- } \\
\text { dependent manner, while this relaxation was significantly } \\
\text { inhibited in endothelium-denuded condition and in the presence }\end{array}$ & 48 \\
\hline
\end{tabular}




\begin{tabular}{|c|c|c|c|}
\hline & & $\begin{array}{l}\text { of the endothelial nitric oxide synthase (eNOS) inhibitor, N(W)- } \\
\text { nitro-L-arginine methyl ester (L-NNA, } 100 \text { microM), an } \\
\text { unselective soluble guanylate cyclase blocker, methylene blue } \\
\text { (10 microM) and the selective sGC inhibitor } 1 \mathrm{H}-[1,2,4] \\
\text { oxadiazolo[4,3- A]quinoxalin-1-one (ODQ, } 1 \text { microM); in } \\
\text { addition, atropine ( } 1 \text { microM), a selective muscarinic receptor } \\
\text { antagonist, partially affected the relaxation. However, the } \\
\text { cyclooxygenase inhibitor indomethacin ( } 5 \text { microM) had no } \\
\text { influence on the relaxant action. Echinacoside enhanced the } \\
\text { cyclic guanosine monophosphate (cGMP) production in aortic } \\
\text { rings contracted with PE. The authors concluded that } \\
\text { echinacoside mediates the endothelium-dependent vasodilator } \\
\text { action in rat thoracic aortic rings through nitric oxide (NO)- } \\
\text { cGMP pathway.The methanolic extract from the dried stems of } \\
\text { Cistanche tubulosa showed inhibitory effect on contractions } \\
\text { induced by noradrenaline in isolated rat aortic strips. From the } \\
\text { extract, new phenylethanoid oligoglycoside constituents, } \\
\text { kankanosides F and G, and an acylated oligosugar, kankanose, } \\
\text { were isolated together with } 14 \text { known compounds. Kankanoside } \\
\text { F, kankanose, echinacoside, acteoside, and cistanoside F, showed } \\
\text { vasorelaxant activity. }\end{array}$ & \\
\hline \multirow[t]{3}{*}{ Citrus species } & $\begin{array}{l}\text { the juice of two } \\
\text { different citrus fruits }\end{array}$ & $\begin{array}{l}\text { The effect of drinking the juice of two different citrus fruits on } \\
\text { vascular neointima formation was studied using a cuff-induced } \\
\text { vascular injury mouse model. Male C57BL6 mice were divided } \\
\text { into five groups as follows: 1) Control (water) (C), 2) } 10 \% \text { citrus } \\
\text { unshiu (CU) juice (CU10), 3) } 40 \% \text { CU juice (CU40), 4) } 10 \% \\
\text { citrus iyo (CI) juice (CI10), and 5) } 40 \% \text { CI juice (CI40). After } \\
\text { drinking them for } 2 \text { weeks from } 8 \text { weeks of age, cuff injury was } \\
\text { induced by polyethylene cuff placement around the femoral } \\
\text { artery. Neointima formation was significantly attenuated in } \\
\text { CU40, CI10 and CI40 compared with C. However, no } \\
\text { remarkable preventive effect was observed in CU10. The } \\
\text { increases in levels of various inflammatory markers including } \\
\text { cytokines such as monocyte chemotactic protein-1, interleukin-6 } \\
\text { (IL-6), IL-1 } \beta \text {, and tumor necrosis factor- } \alpha \text { in response to vascular } \\
\text { injury did not differ significantly between C, CU10 and CI10. } \\
\text { The increases in cell proliferation and superoxide anion } \\
\text { production were markedly attenuated in CI10, but not in CU10 } \\
\text { compared with C. The increase in phosphorylated ERK } \\
\text { expression was markedly attenuated both in CU10 and CI10 } \\
\text { without significant difference between CU10 and CI10. } \\
\text { Accumulation of immune cells did not differ between CU10 and } \\
\text { CI10. The results indicate that drinking citrus fruit juice } \\
\text { attenuates vascular remodeling partly via a reduction of oxidative } \\
\text { stress. }\end{array}$ & 49 \\
\hline & $\begin{array}{l}\text { Citrus aurantifolia } \\
\text { fruit }\end{array}$ & $\begin{array}{l}\text { The cardiovascular effects of Citrus aurantifolia fruit were } \\
\text { studied experimentally. The anti-hypertensive effect was tested } \\
\text { on three experimental hypertensive models including cadmium } \\
\text { induced hypertensive model, glucose induced hypertensive } \\
\text { model, Egg feed diet induced hypertensive model, and } \\
\text { normotensive model. The systolic pressure, diastolic pressure, } \\
\text { mean blood pressure and heart rate of Spargue Daweley rats } \\
\text { were measured by tail cuff method from the tail of rats using } \\
\text { non-invasive blood pressure instrument and body weights were } \\
\text { also measured. Three different doses were used for screening } \\
0.25 \text {, 05, and } 0.75 \mathrm{~g} / \mathrm{kg} \text {, orally given and there effects on } \\
\text { normotensive rats were observed at } 2 \mathrm{hr} \text {, } 4 \mathrm{hr} \text { and } 6 \mathrm{hr} \text { intervals. } \\
\text { The dose of } 0.75 \mathrm{~g} / \mathrm{kg} \text { was selected because it significantly } \\
\text { reduced the mean blood pressure, systolic blood pressure, } \\
\text { diastolic blood pressure, and heart rate. The methanol extract of } \\
\text { Citrus aurantifolia, administered at the dose of } 0.75 \mathrm{mg} \text { orally, } \\
\text { significantly (p<0.01) reduced systolic blood pressure, mean } \\
\text { blood pressure, diastolic blood pressure, heart rate and body } \\
\text { weight of Spargue Dawely rats in both normotensive and } \\
\text { hypertensive experimental models when compared to control } \\
\text { groups. }\end{array}$ & 50 \\
\hline & $\begin{array}{l}\text { aqueous extract of } \\
\text { Citrus aurantifolia }\end{array}$ & $\begin{array}{l}\text { The effects of an aqueous extract of Citrus aurantifolia on } \\
\text { arterial blood pressure and on isolated heart and aorta activities } \\
\text { was evaluated experimentally. Rabbits were used for the study } \\
\text { on the arterial blood pressure using a Ludwig manometer. Albino } \\
\text { Wistar rats were used for the isolated heart and aorta activities } \\
\text { using isolated organ bath systems. Aqueous extract of Citrus } \\
\text { aurantifolia }(4 \mathrm{mg} / \mathrm{kg}-16 \mathrm{mg} / \mathrm{kg} \text { bw) produced a dose-dependent } \\
\text { and significant decrease in rabbit blood pressure }(\mathrm{p}<0.05) \text {. This }\end{array}$ & 51 \\
\hline
\end{tabular}




\begin{tabular}{|c|c|c|c|}
\hline & & $\begin{array}{l}\text { hypotension was not prevented by atropine }(2 \mathrm{mg} / \mathrm{kg} \mathrm{bw} \\
\text { p>0.05). Aqueous extract }(4 \mathrm{mg} / \mathrm{kg}-16 \mathrm{mg} / \mathrm{kg} \mathrm{bw}) \text { was dose- } \\
\text { dependently reduced hypertension evoked by adrenalin }(30 \mu \mathrm{g} / \mathrm{kg} \\
\text { bw). The extract also induced both negative inotropic and } \\
\text { chronotropic effects on the heart contractile activity. The extract } \\
\text { induced a dose dependent relaxation of contractions produced by } \\
\text { adrenalin or by KCl. Aqueous extract of Citrus aurantifolia } \\
\text { evoked vasorelaxant effects were totally abolished by removal of } \\
\text { the endothelium layer or by a pretreatment with L-NAME. }\end{array}$ & \\
\hline & $\begin{array}{l}\text { the aqueous extract of } \\
\text { C. medica limetta }\end{array}$ & $\begin{array}{l}\text { The antihypertensive effect of } C \text {. medica limetta leaves was } \\
\text { investigated against the acute response of blood pressure to } \\
\text { angiotensin II administration The results showed that different } \\
\text { concentrations of the aqueous extract prevented the raise of } \\
\text { systolic blood pressure ( } \leq 0.001 \text { vs. vehicle), diastolic blood } \\
\text { pressure ( } \mathrm{p} \leq 0.0002 \mathrm{vs} \text {. vehicle) and mean blood pressure ( } \mathrm{p} \leq \\
0.0000 \mathrm{vs} \text {. vehicle); with a dose dependent effect for diastolic } \\
\text { pressures at } 125-500 \mathrm{mg} / \mathrm{kg} \text { dosages. The } 500 \text { and } 1000 \mathrm{mg} / \mathrm{kg} \\
\text { doses inhibited the action of Ang II in similar extent to } \\
\text { telmisartan. Toxic signs or deaths were not observed in mice } \\
\text { treated with a dose of } 2000 \mathrm{mg} / \mathrm{kg} \text {. }\end{array}$ & 52 \\
\hline & $\begin{array}{l}\text { orange } \\
\text { sinensis) juice }\end{array}$ & $\begin{array}{l}\text { Four-week consumption of orange juice in healthy middle-aged, } \\
\text { normal-weight men reduced diastolic blood pressure (DBP). } \\
\text { However, the effects of four-week intake of natural and } \\
\text { commercial orange (Citrus sinensis) juice (CSJ) on blood } \\
\text { pressure was evaluated in healthy volunteers. } 22 \text { healthy subjects } \\
\text { were included and randomly divided into two groups. Group A } \\
\text { consumed commercial CSJ during the first four-week period. } \\
\text { After a two-week washout period, they consumed natural CSJ for } \\
\text { another four weeks. The procedure was reversed in group B. The } \\
\text { participants were asked to drink } 500 \mathrm{ml} / \text { day of either natural or } \\
\text { commercial CSJ twice a day with breakfast and dinner. After } \\
\text { drinking commercial CSJ, diastolic and systolic blood pressure } \\
\text { were significantly decreased (5.13\%; P = } 0.03 \text { and }-5.91 \% \text {; P = } \\
0.003 \text {, respectively). However, consumption of natural CSJ did } \\
\text { not have significant effects on either diastolic or systolic blood } \\
\text { pressure. Higher flavonoid, pectin, and essential oils content of } \\
\text { concentrated products compared to natural juice might have been } \\
\text { responsible for this effect. }\end{array}$ & 53 \\
\hline & $\begin{array}{l}\text { water extract of Citrus } \\
\text { unshiu }\end{array}$ & $\begin{array}{l}\text { An attempt was made to isolate hypotensive substances from a } \\
\text { hot water extract of Citrus unshiu. Six flavonoid glycosides were } \\
\text { isolated by repeated chromatography and gel filtration after } \\
\text { extraction with butanol and treatment with lead subacetate. Each } \\
\text { component was intravenously injected into SHR-SP rats (1 } \\
\text { mg/100g body weight), 3,6-di-C-glucosylapigenin and rutin were } \\
\text { found to lower their blood pressure. }\end{array}$ & 54 \\
\hline Cordia myxa & $\begin{array}{l}\text { mucilage from both } \\
\text { ripe and unripe Cordia } \\
\text { obliqua }\end{array}$ & $\begin{array}{l}\text { Mucilage from both ripe and unripe Cordia obliqua (RCo and } \\
\text { URCo) decreased rabbit blood pressure and stimulated the } \\
\text { respiratory rate. URCo was } 12.37 \text {-fold more potent as a } \\
\text { hypotensive agent than RCo. Investigation of the mode of action } \\
\text { revealed that the hypotensive effect was more likely due to } \\
\text { activation of parasympathetic ganglia and dilatation of peripheral } \\
\text { blood vessels. }\end{array}$ & $55-56$ \\
\hline \multirow[t]{2}{*}{ Coriandrum sativum } & crude extract & $\begin{array}{l}\text { Coriander crude extract }(1-30 \mathrm{mg} / \mathrm{ml}) \text { caused fall in arterial blood } \\
\text { pressure of anesthetized animals which partially blocked by } \\
\text { atropine. Coriander crude extract produced vasodilatation against } \\
\text { phenylephrine and } \mathrm{K}+(80 \mathrm{mM}) \text {-induced contractions in rabbit } \\
\text { aorta and caused cardio-depressant effect in guinea-pig atria. } \\
\text { Bioassay-directed fractionation revealed the separation of } \\
\text { spasmogenic and spasmolytic components in the aqueous and } \\
\text { organic fractions respectively. Furthermore, Coriander crude } \\
\text { extract produced diuresis in rats at } 1-10 \mathrm{mg} / \mathrm{kg} \text {. }\end{array}$ & $57-58$ \\
\hline & aqueous extracts & $\begin{array}{l}\text { The water extract of coriander seed had hypotensive effects in } \\
\text { rats. Aqueous extracts of coriander seeds inhibited the } \\
\text { electrically- evoked contractions of spiral strips and tubular } \\
\text { segments of isolated central ear artery of rabbit. }\end{array}$ & $59-60$ \\
\hline Crocus sativus & aqueous extracts & $\begin{array}{l}\text { The effect of Crocus sativus on } \mathrm{Ca}^{2+} \text { influx in isolated rat aortas } \\
\text { was investigated by using }{ }^{45} \mathrm{Ca} \text { as a radioactive tracer. } \mathrm{Ca}^{2+} \\
\text { uptake in isolated rat aorta rings in normal physiological status } \\
\text { was not markedly altered by these drugs, whereas the } \mathrm{Ca}^{2+} \\
\text { influxes induced by norepinephrine of } 1.2 \mathrm{mmol} / 1 \text { and } \mathrm{KCl} \text { of } \\
100 \mathrm{mmol} / \mathrm{l} \text { were significantly inhibited by crocus in a } \\
\text { concentration-dependent manner. The results showed that } \\
\text { extracellular } \mathrm{Ca}^{2+} \text { influx through receptor-operated } \mathrm{Ca}^{2+} \text { channels } \\
\text { and potential dependent } \mathrm{Ca}^{2+} \text { channels can be blocked by crocus. }\end{array}$ & 61 \\
\hline
\end{tabular}




\begin{tabular}{|c|c|c|c|}
\hline & $\begin{array}{l}\text { ethanol extracts of } \\
\text { petals }\end{array}$ & $\begin{array}{l}\text { The effects of Crocus sativus petals' extract on blood pressure } \\
\text { was evaluated on anaesthetized rats. Aqueous and ethanol } \\
\text { extracts of Crocus sativus petals reduced the blood pressure in a } \\
\text { dose-dependent manner. Administration of } 50 \mathrm{mg} / 100 \mathrm{~g} \text { of } \\
\text { aqueous extract changed the blood pressure from } 133.5 \pm 3.9 \text { to } \\
117 \pm 2.1 \text { (mmHg). The effects of saffron (Crocus sativus) stigma } \\
\text { aqueous extract and two active constituents, crocin and safranal, } \\
\text { were investigated on blood pressure of normotensive and } \\
\text { desoxycorticosterone acetate-induced hypertensive rats. Three } \\
\text { doses of crocin ( } 50,100 \text { and } 200 \mathrm{mg} / \mathrm{kg}) \text {, safranal }(0.25,0.5 \text { and } \\
1 \text { mg/kg) and the aqueous extract }(2.5,5 \text { and } 10 \mathrm{mg} / \mathrm{kg}) \text { were } \\
\text { administered intravenously in different groups of normotensive } \\
\text { and hypertensive animals and their effects on mean arterial blood } \\
\text { pressure (MABP) and heart rate (HR) were evaluated. The } \\
\text { aqueous extract of saffron stigma, safranal and crocin reduced } \\
\text { the MABP in normotensive and hypertensive anaesthetized rats } \\
\text { in a dose-dependent manner. Administrations of } 10 \mathrm{mg} / \mathrm{kg} \text { of } \\
\text { aqueous extract, } 1 \mathrm{mg} / \mathrm{kg} \text { of safranal and } 200 \mathrm{mg} / \mathrm{kg} \text { of crocin } \\
\text { caused } 60 \pm 8.7,50 \pm 5.2 \text { and } 51 \pm 3.8 \mathrm{mmHg} \text { reductions in } \\
\text { MABP, respectively. Accordingly, the aqueous extract of saffron } \\
\text { stigma had hypotensive properties which appear to be } \\
\text { attributable, in part, to the actions of two major constitutes of this } \\
\text { plant, crocin and safranal, and safranal was more important than } \\
\text { crocin for lowering the blood pressure of rats. }\end{array}$ & 62 \\
\hline & aqueous extract & $\begin{array}{l}\text { The effects of saffron (Crocus sativus) stigma aqueous extract } \\
\text { was studied on blood pressure of normotensive and } \\
\text { desoxycorticosterone acetate (DOCA)-salt induced hypertensive } \\
\text { rats. Five weeks administration of three doses saffron aqueous } \\
\text { extract ( } 10,20 \text { and } 40 \mathrm{mg} / \mathrm{Kg} / \text { day) and spironolactone ( } 50 \\
\mathrm{mg} / \mathrm{Kg} / \text { day) in different groups of normotensive and } \\
\text { hypertensive rats (at the end of } 4 \text { weeks treatment by DOCA- } \\
\text { salt) showed that chronic administration of saffron aqueous } \\
\text { extract reduced the MSBP in DOCA salt treated rats in a dose } \\
\text { dependent manner. It did not decrease the MSBP in } \\
\text { normotensive rats. The data also showed that the } \\
\text { antihypertensive effects of saffron did not persist. }\end{array}$ & 63 \\
\hline & crocetin & $\begin{array}{l}\text { The vasomodulatory effects of crocetin was analyzed in } \\
\text { hypertension. Myographical experiments were performed to } \\
\text { compare the relaxation induced by acetylcholine (ACH) on aortic } \\
\text { rings from normotensive (Wistar) and hypertensive (SHR) rats, } \\
\text { incubated with or without crocetin or saffron extract and L- } \\
\text { NAME or indomethacin. Extracts were also assayed in } \\
\text { deendothelialized rings. Crocetin enhanced the ACH relaxations } \\
\text { in aorta from hypertensive (strongly) and normotensive rats } \\
\text { (weakly). Crocetin plus L-NAME abolished the relaxant } \\
\text { response in SHR but not in Wistar aorta. Crocetin plus } \\
\text { indomethacin did not modify the indomethacin response in either } \\
\text { SHR or Wistar aorta. Crocetin in rubbed segments did not } \\
\text { modify the ACH responses. In contrast, saffron increased this } \\
\text { response in rubbed segments from SHR but not Wistar rats. } \\
\text { Accordingly, crocetin exerts healthy vasomodulatory effects in } \\
\text { hypertension, strongly improving endothelium-dependent ACH } \\
\text { relaxations via endothelial nitric oxide but not the } \\
\text { cyclooxygenase pathway. }\end{array}$ & 64 \\
\hline Cuminum cyminum & $\begin{array}{l}\text { aqueous extract of } \\
\text { seeds }\end{array}$ & $\begin{array}{l}\text { The anti-hypertensive potential of standardized aqueous extract } \\
\text { of Cuminum cyminum seeds and its role in arterial endothelial } \\
\text { nitric oxide synthase expression, inflammation, and oxidative } \\
\text { stress were evaluated in renal hypertensive rats. Renal } \\
\text { hypertension was induced by the two-kidney one-clip (2K/1C) } \\
\text { method in rats. Systolic blood pressure (SBP), plasma } \\
\text { nitrate/nitrite, carotid-eNOS, renal-TNF- } \alpha \text {, IL- } 6 \text {, Bax, Bcl-2, } \\
\text { thioredoxin } 1 \text { (TRX1), and thioredoxin reductase } 1 \text { (TRXR1) } \\
\text { mRNA expressions were studied to demonstrate the anti- } \\
\text { hypertensive action of Cuminum cyminum. Cuminum cyminum } \\
\text { seed was administered orally ( } 200 \text { mg/kg bw) for a period of } 9 \\
\text { weeks, it improved plasma nitric oxide and decreased the systolic } \\
\text { blood pressure in hypertensive rats. It also up-regulated the gene } \\
\text { expression of eNOS, Bcl-2, TRX1, and TRXR1; and down- } \\
\text { regulated Bax, TNF- } \alpha \text {, and IL- } 6 \text {. The data revealed that } \\
\text { Cuminum cyminum seeds augment endothelial functions and } \\
\text { ameliorate inflammatory and oxidative stress in hypertensive } \\
\text { rats. }\end{array}$ & 65 \\
\hline Cydonia oblonga & ethanol leaf extracts & $\begin{array}{l}\text { The effect of ethanol leaf extracts of Cydonia oblonga Mill. } \\
(\mathrm{COM}) \text { was studied on hypertension and on biomarkers }\end{array}$ & 66 \\
\hline
\end{tabular}




\begin{tabular}{|c|c|c|c|}
\hline & & $\begin{array}{l}\text { associated with blood pressure control, such as angiotensin-II } \\
\text { (AII), plasma renin activity (PRA), apelin- } 12 \text { (A), endothelin } \\
\text { (ET) and nitric oxide (NO), compared to captopril. Two-kidney } \\
\text { one-clip ( } 2 \mathrm{~K} 1 \mathrm{C} \text { ) Goldblatt model rats were divided randomly } \\
\text { into six groups: sham, model, captopril } 25 \mathrm{mg} / \mathrm{kg} \text {, COM leaf } \\
\text { extract } 80,160 \text { and } 320 \mathrm{mg} / \mathrm{kg} \text {. Drugs were administered orally } \\
\text { daily for eight weeks. Systolic blood pressure (SBP) and } \\
\text { diastolic blood pressure (DBP) were measured before treatment } \\
\text { and every } 2 \text { weeks. Blood and kidney samples were collected } \\
\text { after the last treatment to measure AII, PRA, A, ET and NO. } \\
\text { Renal hypertensive rats (RHR) had increased blood pressure, } \\
\text { AII, A, PRA, ET and decreased NO. Treatment with captopril } \\
\text { reduced blood pressure, AII, A, PRA, and ET, though not quite } \\
\text { to normal values. COM leaf extracts significantly and dose- } \\
\text { dependently reduced blood pressure, AII, A, RA and ET, } \\
\text { whereas NO was increased. The effects of COM extracts on } \\
\text { blood pressure and biomarkers were dose-dependent and at the } \\
\text { highest dose, it produced effects similar to those of captopril. }\end{array}$ & \\
\hline & $\begin{array}{l}\text { fruit and leaf } \\
\text { ethanolic extracts }\end{array}$ & $\begin{array}{l}\text { The effects of Cydonia oblonga. (COM) fruit and leaf extracts on } \\
\text { blood pressure and rheology were studied in renal hypertensive } \\
\text { rats (RHR). Daily doses of } 80 \text { and } 160 \mathrm{mg} / \mathrm{kg} \text { aqueous or ethanol } \\
\text { extracts of COM fruit or leaves, or } 25 \mathrm{mg} / \mathrm{kg} \text { captopril were given } \\
\text { orally once daily for } 8 \text { weeks. Blood pressure was measured } \\
\text { before treatment and every } 2 \text { weeks thereafter. Blood rheology } \\
\text { was tested after } 8 \text { weeks. Model rats had higher blood pressure } \\
\text { than sham, } 8 \text { weeks after the procedure (systolic blood pressure } \\
193 \pm 7 \text { vs. } 138 \pm 8 \mathrm{mmHg} \text {, p }<0.05 \text { ). Those treated with captopril } \\
\text { had decreased blood pressure within } 2 \text { weeks but that did not } \\
\text { return to the level found in the sham group at } 8 \text { weeks ( } 167 \pm 7 \text {, } \\
\text { p }<0.05 \text { vs. model). With the COM extracts, the effect on blood } \\
\text { pressure was notable after } 4 \text { weeks. At } 8 \text { weeks blood pressure } \\
\text { was similar with captopril and with } 160 \mathrm{mg} \text { ethanol leaf extract } \\
\text { (166 } 4 \text {, p<0.05 vs. model), it was the most effective of the } \\
\text { extracts. Model rats had higher blood viscosity and lower } \\
\text { erythrocyte deformability than sham. Captopril had little effect } \\
\text { on blood rheology; whereas COM extracts reduced whole blood } \\
\text { viscosity and improved erythrocyte deformability to levels } \\
\text { approaching those found in sham. }\end{array}$ & 67 \\
\hline \multirow[t]{2}{*}{ Daucus carota } & ethanolic extract & $\begin{array}{l}\text { Ethanolic extract of Daucus carota at the dose of } 10-100 \mathrm{mg} / \mathrm{kg} \\
\text { caused a dose-dependent fall in systolic and diastolic arterial } \\
\text { blood pressure in normotensive anesthetized rats. These effects } \\
\text { were not blocked by atropine ( } 1 \mathrm{mg} / \mathrm{kg}) \text {. Pretreatment with } \\
\text { Daucus carota did not alter the pressor response to } \\
\text { norepinephrine indicating that, cardiovascular effects of Daucus } \\
\text { carota were independent of cholinergic or adrenergic receptors } \\
\text { involvement. In spontaneously beating guinea-pig paired atria, } \\
\text { Daucus carota induced a concentration-dependent }(0.3-5 \\
\text { mg/ml) decrease in force and rate of atrial contractions. In rabbit } \\
\text { thoracic aorta, Daucus carota caused inhibition of } \mathrm{K}^{+} \text {-induced } \\
\text { contractions at similar concentrations. }\end{array}$ & $68-69$ \\
\hline & $\begin{array}{l}\text { two cumarin } \\
\text { glycosides isolated } \\
\text { from the aerial parts }\end{array}$ & $\begin{array}{l}\text { Fractionation of aerial parts of Daucus carota resulted in the } \\
\text { isolation of two cumarin glycosides coded as DC- } 2 \text { and DC- } 3 \text {. } \\
\text { Intravenous administration ( } 1-10 \mathrm{mg} / \mathrm{kg} \text { ) of these compounds } \\
\text { caused a dose-dependent fall in arterial blood pressure in } \\
\text { normotensive anaesthetised rats, Both compounds caused a dose- } \\
\text { dependent }(10-200 \mathrm{pg} / \mathrm{ml}) \text { inhibitory effect on spontaneously } \\
\text { beating guinea pig atria as weIl as on the Kt-induced contractions } \\
\text { of rabbit aorta at similar concentrations in vitro. The results } \\
\text { indicated that DC- } 2 \text { and DC- } 3 \text { acting through blockade of } \\
\text { calcium channels, the effect which may be responsible for the } \\
\text { blood pressure lowering effect of the compounds observed in the } \\
\text { in vivo studies. }\end{array}$ & 70 \\
\hline
\end{tabular}

Plants with cardiac effect:

\begin{tabular}{|l|l|l|l|}
\hline Plant & The tested constituent & Activity & Ref \\
\hline
\end{tabular}




\begin{tabular}{|c|c|c|c|}
\hline \multirow[t]{2}{*}{ Adonisa estivalis } & $\begin{array}{l}\text { strophanthidin } \\
\text { aglycone }\end{array}$ & $\begin{array}{l}\text { Strophanthidin aglycone is one of several } \\
\text { cardenolides extracted from Adonisa estivalis. } \\
\text { The direct effect elicited by these compounds } \\
\text { is similar to other cardiac glycoside-containing } \\
\text { plants and is due to inhibition of the sodium } \\
\text { potassium adenosine triphosphatase enzyme } \\
\text { system pump. Theyincrease vagal tone, which } \\
\text { decreases the rate of sinoatrial node } \\
\text { depolarization. In intoxication, the electro } \\
\text { cardiographic changes seen are include } \\
\text { bradycardia, varying levels of atrioventricular } \\
\text { block, ventricular arrhythmias, and ventricular } \\
\text { fibrillation. }\end{array}$ & $71-72$ \\
\hline & $\begin{array}{l}\text { tincture of Adonis } \\
\text { vernalis }\end{array}$ & $\begin{array}{l}\text { Tincture of Adonis vernalis is used by } \\
\text { homeopathic physicians in patients suffering } \\
\text { from congestive cardiac failure. Its action was } \\
\text { very much similar to digitalis on heart. Aqueous } \\
\text { extract of Adonisvernalis was found to have } \\
\text { cardiac stimulant action on isolated heart } \\
\text { preparations. It showed protection against heart } \\
\text { failure produced by excessive load and high } \\
\text { potassium concentration. Tincture of Adonis } \\
\text { vernalis was found to cause cardiac depression } \\
\text { which was not blocked by the atropine. In } \\
\text { isolated guinea pig and rabbit auricles the drug } \\
\text { increased the threshold of electrical stimulation. }\end{array}$ & 4,73 \\
\hline Alhagi maurorum & ethanolic extract & $\begin{array}{l}\text { In evaluation the effect of the ethanolic extract } \\
\text { of Alhagi maurorum powdered roots in } \\
\text { anaesthetized rats, the results revealed that the } \\
\text { extract at a dose of } 1 \mathrm{~g} / \mathrm{kg} \text { induced bradycardia } \\
\text { only and not myocardial depressant. Glyceryl- } \\
\text { n-tetracosan- } 17 \text {-ol- } 1 \text {-oate ( a new aliphatic } \\
\text { ester isolated from the root of the plant) } \\
\text { possessed a heart rate stimulant action and a } \\
\text { myocardial depressant action on rat isolated } \\
\text { heart. }\end{array}$ & $74-75$ \\
\hline Althaea rosea & $\begin{array}{l}\text { Alcoholic extract of } \\
\text { the flower }\end{array}$ & $\begin{array}{l}\text { Alcoholic extract of the flower of Althaea rosea } \\
\text { (L.)increased the outflow of coronary artery of } \\
\text { isolated guinea pig's heart and markedly dilated } \\
\text { the blood vessels in the hind-limbs of rats. The } \\
\text { extract showed a transient hypotensive effect on } \\
\text { anesthetic cats. It inhibited platelet aggregation } \\
\text { induced by ADP and showed a inhibitory effect } \\
\text { on experimental thrombosis formation. }\end{array}$ & 76 \\
\hline \multirow[t]{2}{*}{ Ammi visnaga } & $\begin{array}{l}\text { Extract, samidin and } \\
\text { khellol }\end{array}$ & $\begin{array}{l}\text { Ammi visnaga induced relaxation of smooth } \\
\text { muscle, including that coronary arteries, in a } \\
\text { variety of animal species. Samidin and khellol } \\
\text { glucoside induced positive inotropic effects on } \\
\text { heart. A clinical trial of khellin in } 38 \text { cases of } \\
\text { angina pectoris and in } 8 \text { cases of coronary } \\
\text { thrombosis was performed. Continuous } \\
\text { treatment, by the oral or intramuscular routes or } \\
\text { by both, gave favourable results in } 35 \text { out of } 38 \\
\text { cases of angina pectoris. Continuously } \\
\text { administration of khellin for several weeks to } \\
\text { eight patients after coronary thrombosis } \\
\text { appeared favourable. }\end{array}$ & $77-78$ \\
\hline & khellin & $\begin{array}{l}\text { Immediately after the rapid intravenous } \\
\text { administration of } 20-30 \mathrm{mg} \text { of khellin to the }\end{array}$ & 79 \\
\hline
\end{tabular}




\begin{tabular}{|c|c|c|c|}
\hline & & $\begin{array}{l}\text { dogs, the heart beats considerably slower. The } \\
\text { entire effect lasts for only a short time, within a } \\
\text { minute or two. }\end{array}$ & \\
\hline Anchusa strigosa & $\begin{array}{l}\text { Aqueous extracts of } \\
\text { the flowers }\end{array}$ & $\begin{array}{l}\text { The extract was found to have slight inhibitory } \\
\text { effect on the auricular contraction in bilaterally } \\
\text { vagotomised dog but there was no effect on } \\
\text { ventricular contraction in this animal. These } \\
\text { results indicate that the site of action is } \\
\text { probably blood vessel. }\end{array}$ & $80-81$ \\
\hline Apium graveolens & $\begin{array}{l}\text { aqueous and ethanol } \\
\text { extracts }\end{array}$ & $\begin{array}{l}\text { Both aqueous and ethanol extracts exhibit a } \\
\text { negative chronotropic and inotropic actions. } \\
\text { Aqueous extract decreased the rate of } \\
\text { contractions by } 12.88 \pm 2.74 \% \text { and amplitude by } \\
8.73 \pm 0.89 \% \text {. Ethanol extract inhibited the rate } \\
\text { of atria contractions by } 34.26 \pm 5.69 \% \text { and } \\
\text { amplitude by } 25.40 \pm 3.61 \% \text {. Pretreatment of rat } \\
\text { atria with atropine }(1 \mu \mathrm{M}) \text { partially blocked the } \\
\text { inhibitory response induced by aqueous and } \\
\text { ethanol extracts of Apium graveolens. }\end{array}$ & 82 \\
\hline Asclepias curassavica & asclepin & $\begin{array}{l}\text { Asclepin extracted from Asclepias curassavica } \\
\text { showed positive inotropic activity; it was more } \\
\text { potent, and safer than other cardiac glycosides } \\
\text { (including digoxin). It showed longer duration } \\
\text { of action than digoxin ( } 96 \mathrm{~h} \text { in cat, as opposed } \\
\text { to the } 72 \mathrm{~h} \text { of digoxin). }\end{array}$ & 83 \\
\hline Bacopa monnieri & $\begin{array}{l}\text { ethanolic extract of } \\
\text { whole plant }\end{array}$ & $\begin{array}{l}\text { Ethanolic extract of whole plant of Bacopa } \\
\text { monnieri has shown cardiac depressive activity } \\
\text { on left ventricular contractility, heart rate and } \\
\text { coronary flow in isolated rabbit heart and it } \\
\text { appeared that, the activity of ethanolic Bacopa } \\
\text { monnieri extract was similar to that of } \\
\text { quinidineon heart. }\end{array}$ & $84-85$ \\
\hline Brassica nigra & mustard & $\begin{array}{l}\text { Mustard stimulated the cardiac and respiratory } \\
\text { activity in sufficient force to arouse one from an } \\
\text { attack of fainting. Both the breathing and } \\
\text { circulation are stimulated by its reflex action } \\
\text { upon the respiratory center and the heart. }\end{array}$ & $86-87$ \\
\hline Caesalpinia crista & $\begin{array}{l}\text { alcoholic and aqueous } \\
\text { extract }\end{array}$ & $\begin{array}{l}\text { The alcoholic and aqueous extract was } \\
\text { evaluated for protection against isoproterenol } \\
(85 \mathrm{mg} / \mathrm{kg} \text { bw) induced myocardial infarction in } \\
\text { albino rats. Pretreatment with an ethanolic and } \\
\text { aqueous extract at a dose of } 400 \mathrm{mg} / \mathrm{kg} \text {, orally } \\
\text { for } 30 \text { days, reduced significantly }(\mathrm{p}<0.01) \text { the } \\
\text { elevated marker enzyme levels in serum and } \\
\text { heart homogenates in isoproterenol - induced } \\
\text { myocardial infarction. Histopathological } \\
\text { observation revealed a marked protection by the } \\
\text { extract in myocardial necrotic damage. }\end{array}$ & 88 \\
\hline Calendula officinalis & calendula solution & $\begin{array}{l}\text { Rat hearts perfused with calendula solution at } \\
50 \mathrm{mM} \text { in KHB buffer for } 15 \mathrm{~min} \text { prior to } \\
\text { subjecting the heart to ischemia, showed } \\
\text { cardioprotection by stimulating left ventricular } \\
\text { developed pressure and aortic flow as well as } \\
\text { by reducing myocardial infarct size and } \\
\text { cardiomyocyte apoptosis. Cardioprotection } \\
\text { appears to be achieved by changing ischemia } \\
\text { reperfusion-mediated death signal into a } \\
\text { survival signal by modulating antioxidant and } \\
\text { anti-inflammatory pathways as evidenced by }\end{array}$ & $89-90$ \\
\hline
\end{tabular}




\begin{tabular}{|c|c|c|c|}
\hline & & $\begin{array}{l}\text { the activation of Akt and } \mathrm{Bcl} 2 \text { and depression } \\
\text { of TNF } \alpha \text {. }\end{array}$ & \\
\hline \multirow[t]{2}{*}{ Calotropis procera } & ethanolic latex extract & $\begin{array}{l}\text { Latex was evaluated for protection against } \\
\text { isoproterenol }(20 \mathrm{mg} / 100 \mathrm{~g}) \text { induced myocardial } \\
\text { infarction in albino rats. The pretreatment with } \\
\text { an ethanolic latex extract at a dose of } 300 \\
\mathrm{mg} / \mathrm{kg} \text { body weight orally three times a day for } \\
30 \text { days, reduced significantly }(\mathrm{p}<0.01) \text { the } \\
\text { elevated markers enzyme levels in serum and } \\
\text { heart homogenates in isoproterenol induced } \\
\text { myocardial infarction. }\end{array}$ & $91-92$ \\
\hline & $\begin{array}{l}\text { ethanol, n-butanol, } \\
\text { ethyl acetate extracts } \\
\text { and latex }\end{array}$ & $\begin{array}{l}\text { The effects of ethanol, n-butanol, and ethyl } \\
\text { acetate (EtOAc) extracts of the aerial parts of } \\
\text { the plant, were evaluated on isolated toad heart. } \\
\text { Their mechanisms of action were also studied. } \\
\text { Perfusion with } 2 \mu \mathrm{g} / \mathrm{ml} \text { ethanol, } 0.2 \mu \mathrm{g} / \mathrm{mL} \\
\text { butanol, and } 0.2 \mu \mathrm{g} / \mathrm{mL} \text { EtOAc extracts caused } \\
\text { a significant decrease in heart rate } \\
\text { (bradycardia), significant increase in the force } \\
\text { of ventricular contraction, and increase in T- } \\
\text { wave amplitude. The different extracts and } \\
\text { latex of } C \text {. procera induced negative } \\
\text { chronotropism and positive inotropism on } \\
\text { isolated toad heart. }\end{array}$ & 93 \\
\hline \multirow[t]{3}{*}{ Carthamus tinctorius } & $\begin{array}{l}\text { Ethanolic extract of the } \\
\text { petals }\end{array}$ & $\begin{array}{l}\text { An animal model of myocardial ischemia injury } \\
\text { was induced by left anterior descending } \\
\text { coronary artery occlusion in adult rats. } \\
\text { Pretreatment with } C \text {. tinctorius (ECT) (100, } \\
200,400,600 \mathrm{mg} / \mathrm{kg} \text { body wt.) protected the } \\
\text { heart from ischemia injury by limiting infarct } \\
\text { size and improving cardiac function. In the in } \\
\text { vitro experiment, neonatal rat ventricular } \\
\text { myocytes were incubated to test the direct } \\
\text { cytoprotective effect of ECT against } \mathrm{H} 2 \mathrm{O} 2 \\
\text { exposure. Pretreatment with } 100-400 \text { microg/ml } \\
\text { ECT prior to H2O2 exposure significantly } \\
\text { increased cell viability. ECT also markedly } \\
\text { attenuated H2O2-induced cardiomyocyte } \\
\text { apoptosis. The protection is achieved by } \\
\text { scavenging of ROS and mediating the PI3K } \\
\text { signaling pathway. }\end{array}$ & $94-95$ \\
\hline & $\begin{array}{l}\text { Carthamus tinctorius } \\
\text { injection }\end{array}$ & $\begin{array}{l}\text { The effects of safflower injection (SI) in } \\
\text { protecting heart, on energy charge and anti- } \\
\text { apoptosis gen bcl-2 in cardiac tissue were } \\
\text { investigated by Rats' Langendorff isolated heart } \\
\text { infused model. As compared with the control, } \\
\text { SI improved the functions of cardiac } \\
\text { contraction and dilation, increasing coronary } \\
\text { blood flow, and strengthening the bcl-2 protein } \\
\text { expression. }\end{array}$ & 96 \\
\hline & $\begin{array}{ll}\text { Flos } & \text { Carthami } \\
\text { FC(EtOH)) } & \text { ethanolic } \\
\text { extract } & \end{array}$ & $\begin{array}{l}\text { The effect of Flos Carthami } \mathrm{FC}(\mathrm{EtOH})) \\
\text { ethanolic extract on LPS-induced apoptosis in } \\
\mathrm{H} 9 \mathrm{c} 2 \text { cardiomyoblast cells was studied. } \\
\mathrm{FC}(\mathrm{EtOH})(62.5 \text { microg/mL) inhibited LPS- } \\
\text { induced apoptosis by suppressing JNK1/2 } \\
\text { activity, which resulted in the reduction of both } \\
\text { IkappacB degradation and NF kappaB } \\
\text { activation. In addition, FC(EtOH) led to } \\
\text { activation of anti-apoptotic proteins, Bcl-2 and }\end{array}$ & $97-98$ \\
\hline
\end{tabular}




\begin{tabular}{|c|c|c|c|}
\hline & & $\begin{array}{l}\text { Bcl-xL, the stabilization of the mitochondria } \\
\text { membrane and the down-regulation of extrinsic } \\
\text { and intrinsic pro-apoptotic proteins, such as } \\
\text { TNF alpha, active caspase- } 8 \text {, t-Bid, Bax, active } \\
\text { caspases-9, and -3. The ability of Carthamus } \\
\text { tinctorius to suppress JNK activity and inhibit } \\
\text { LPS-induced TNF alpha activation and } \\
\text { apoptosis in H9c } 2 \text { cardiomyoblast cells could } \\
\text { potentially serve as a cardio-protective agent } \\
\text { against LPS-induced apoptosis. }\end{array}$ & \\
\hline & $\begin{array}{lr}\text { safflor } & \text { yellow } \\
\text { (SYA), a flavonoid } \\
\text { extracted } & \text { from } \\
\text { Carthamus tinctorius }\end{array}$ & $\begin{array}{l}\text { The effects of safflor yellow A (SYA) was } \\
\text { evaluated on cultured rat cardiomyocytes } \\
\text { exposed to anoxia/reoxygenation (A/R). The } \\
\text { A/R exposure markedly decreased the viability } \\
\text { of cardiomyocytes, suppressed the activities of } \\
\text { SOD, GSH, CAT, GSH-Px, and Bcl-2 protein } \\
\text { expression. Meanwhile, the A/R exposure } \\
\text { markedly increased the release of LDH, CK, } \\
\text { MDA production in the cardiomyocytes, } \\
\text { increased the rate of apoptosis, caspase } 3 \\
\text { activity and Bax protein expression. }\end{array}$ & 99 \\
\hline & safflor yellow B (SYB) & $\begin{array}{l}\text { The protective effect of safflor yellow B (SYB) } \\
\text { was investigated against vascular endothelial } \\
\text { cells (VECs) injury induced by angiotensin-II } \\
\text { (Ang-II). Comparing with control group, Ang-II } \\
\text { was able to increase Ca2+ and ROS level, } \\
\text { decrease MMP level, inhibit complex IV } \\
\text { activity and enhance caspase } 3 \text { activity in } \\
\text { VECs, as a result, enhance apoptosis of VECs. } \\
\text { SYB was able to eliminate the effect of Ang-II } \\
\text { on VECs via regulating Ca+2, mitochondrial } \\
\text { structure and function and inhibiting apoptosis. }\end{array}$ & 100 \\
\hline & $\begin{array}{l}\text { hydroxysafflor yellow } \\
\text { A }\end{array}$ & $\begin{array}{l}\text { Intravenous injection of the hydroxysafflor } \\
\text { yellow A (HSYA) significantly reduced MAP } \\
\text { and HR in both normotensive rats and SHR in a } \\
\text { dose-dependent manner. HSYA reduced left } \\
\text { ventricular systolic pressure (LVSP), left } \\
\text { ventricular end-diastolic pressure (LVEDP), the } \\
\text { maximum rate of increase of left ventricular } \\
\text { pressure (+dp/dt(max)) and heart rate (HR) in a } \\
\text { dose-dependent manner. HSYA had no } \\
\text { remarkable effect on the maximum rate of } \\
\text { decrease of left ventricular pressure (- } \\
\text { dp/dt(max)); BK(Ca) and K(ATP) blocker can } \\
\text { weakened the inhibitory effect of HSYA on } \\
\text { heart function and HR, but K(V) and K(ACh) } \\
\text { blocker did not significantly weaken the HSYA } \\
\text { effects. }\end{array}$ & 42 \\
\hline Cheiranthus cheiri & $\begin{array}{l}\text { Plant glycosides } \\
\text { (cheiranthoside III and } \\
\text { VIII) }\end{array}$ & $\begin{array}{l}\text { Cardiac glycosides called cheiranthosides I-XI } \\
\text { together with two olitoriside and erysimoside } \\
\text { were isolated from the seeds of the plant. The } \\
\text { glycosides were evaluated for their inhibitory } \\
\text { activity against } \mathrm{Na}^{+}, \mathrm{K}^{+}-\mathrm{ATPase} \text { by comparing } \\
\text { with typical cardiac glycosides. Two of them, } \\
\text { cheiranthoside III and VIII, showed high } \\
\text { inhibiting activity which was equivalent to that } \\
\text { of digitoxin. Cheiranthoside XI containing a } \\
\text { rhamnopyranosyl digitoxopyranosyl moiety and } \\
\text { a carboxyl group showed the lowest activity }\end{array}$ & 101 \\
\hline
\end{tabular}




\begin{tabular}{|c|c|c|c|}
\hline & & $\begin{array}{l}\text { which was similar to that of the inactive } \\
\text { aglycone, strophanthidin. }\end{array}$ & \\
\hline Citrus species & $\begin{array}{l}\text { ethanolic extract of } \\
\text { Citrus medica }\end{array}$ & $\begin{array}{l}\text { The protective effect of the ethanolic extract of } \\
\text { Otroj, Citrus medica (EEOT) against } \\
\text { isoproterenol (ISO)-induced cardiotoxicity was } \\
\text { evaluated in rats. Rats were administered EETO } \\
\text { ( } 250 \text { and } 500 \mathrm{mg} / \mathrm{kg} \text { ) or vehicle orally for } 15 \\
\text { days along with ISO ( } 85 \mathrm{mg} / \mathrm{kg} \text {, sc) on the } 14 \text { th } \\
\text { and } 15 \text { th day. ISO induced cardiac dysfunction, } \\
\text { increased lipid peroxidation and alteration of } \\
\text { myocyte-injury specific marker enzymes. ISO } \\
\text { also showed an increase in levels of plasma } \\
\text { cholesterol, triglycerides (TG), LDL-C, and } \\
\text { VLDL-C. Moreover, the histological } \\
\text { investigations showed myocardial necrosis and } \\
\text { inflammation. EETO treatment brought the } \\
\text { above parameters towards normal level. } \\
\text { Moreover, in vitro DPPH radical scavenging } \\
\text { and } \beta \text {-carotene-linoleic acid tests of the EEOT } \\
\text { exhibited a notable antioxidant activity in both } \\
\text { assays used. In addition, histopathological } \\
\text { examination reconfirmed the protective effects } \\
\text { of EEOT. Accordingly } C \text {. medica alleviates } \\
\text { myocardial damage in ISO-induced cardiac } \\
\text { injury and demonstrates cardioprotective } \\
\text { potential. }\end{array}$ & $\begin{array}{l}102- \\
104\end{array}$ \\
\hline \multirow[t]{2}{*}{$\begin{array}{l}\text { Corchorus } \\
\text { aestuans }\end{array}$} & $\begin{array}{l}\text { alcoholic extract and } \\
\text { glycosides of seeds }\end{array}$ & $\begin{array}{l}\text { Alcoholic extract and glycosides of seeds } \\
\text { exhibited cardiotonic activity. }\end{array}$ & 105 \\
\hline & $\begin{array}{l}\text { Cardiac glycoside } \\
\text { isolated from the plant }\end{array}$ & $\begin{array}{l}\text { Cardiac glycoside was isolated from the plant } \\
\text { fruits and tested for cardiotonic activity using } \\
\text { isolated frog heart perfusion technique (IFHP). } \\
\text { A significant increase in the height of force of } \\
\text { contraction (positive inotropic effect) and } \\
\text { decrease in heart rate (negative chronotropic } \\
\text { effect) was observed at smaller doses ( } 0.4 \mathrm{mg} \text { ). } \\
\text { The effect increased as dose was increased. The } \\
\text { test compound had not produced cardiac arrest } \\
\text { even at a dose of } 2 \mathrm{mg} \text {, compared to standard, } \\
\text { digoxin that showed cardiac arrest at dose of } \\
0.2 \text { mg. Hence, as compared to standard, the } \\
\text { tested cardiac glycoside showed wide } \\
\text { therapeutic index. }\end{array}$ & $\begin{array}{l}106- \\
108\end{array}$ \\
\hline $\begin{array}{l}\text { Corchorus } \\
\text { capsularis }\end{array}$ & $\begin{array}{l}\text { Corchortoxin } \\
\text { (strophanthidin) a } \\
\text { cardiac aglycone } \\
\text { isolated from the seeds } \\
\text { of Corchorus } \\
\text { capsularis }\end{array}$ & $\begin{array}{l}\text { Corchortoxin (strophanthidin) was a cardiac } \\
\text { aglycone isolated from Corchorus capsularis } \\
\text { seeds, showed a cardio-tonic activity. These } \\
\text { activities were similar to digitalis genus. } \\
\text { However, jute seeds extract showed better } \\
\text { activities than corchortoxin. Corchoroside A } \\
\text { and B, which also isolated from other plants } \\
\text { also showed digitalis like action. }\end{array}$ & $\begin{array}{l}109- \\
113\end{array}$ \\
\hline Coriandrum sativum & aqueous extracts & $\begin{array}{l}\text { The preventive effect of Coriandrum sativum } \\
\text { (CS) on cardiac damage was evaluated by } \\
\text { isoproterenol induced cardiotoxicity model in } \\
\text { male rats. Rats were pretreated with methanolic } \\
\text { extract of CS seeds at a dose of } 100,200 \text { or } 300 \\
\mathrm{mg} / \mathrm{kg} \text { orally for } 30 \text { days and they were } \\
\text { subsequently administered ( } \mathrm{sc} \text { ) with } \\
\text { isoproterenol ( } 85 \mathrm{mg} / \mathrm{kg} \text { body weight) for the }\end{array}$ & 114 \\
\hline
\end{tabular}




\begin{tabular}{|c|c|c|c|}
\hline & & $\begin{array}{l}\text { last two days. Isoproterenol treated rats showed } \\
\text { increased LPO, decreased levels of endogenous } \\
\text { antioxidants and ATPases in the cardiac tissue } \\
\text { together with increased plasma lipids and } \\
\text { markers of cardiac damage. TTC staining } \\
\text { showed increased infarct areas while HXE } \\
\text { staining showed myofibrillar hypertrophy and } \\
\text { disruption. CS ( } 200 \text { and } 300 \mathrm{mg} / \mathrm{kg} \text { body } \\
\text { weight) pretreatment significantly prevented or } \\
\text { resisted all these changes. The results showed } \\
\text { that methanolic extract of CS is able to prevent } \\
\text { myocardial infarction by inhibiting myofibrillar } \\
\text { damage. It is also postulated that, the rich } \\
\text { polyphenolic content of CS extract was } \\
\text { responsible for preventing oxidative damage by } \\
\text { effectively scavenging the isoproterenol } \\
\text { generated ROS. }\end{array}$ & \\
\hline Coronilla scorpioides & Coronillin & $\begin{array}{l}\text { The physiological studies have demonstrated } \\
\text { that the coronillin was toxic to the heart, its } \\
\text { effect on the heart is similar to digitalis. In } \\
\text { small doses it slowed the pulse through } \\
\text { stimulation of the inhibitory ganglia, and in } \\
\text { larger quantity increased the tonicity and } \\
\text { contractility of the heart, eventually leading to } \\
\text { systolic spasm of the ventricle. This action upon } \\
\text { the heart was accompanied by increase in the } \\
\text { arterial pressure, followed after a time by } \\
\text { lowering of the pressure, which apparently was } \\
\text { the result of failure of diastole, causing the } \\
\text { amount of blood forced out of the heart at each } \\
\text { systole to be insufficient to fill the arteries. }\end{array}$ & $\begin{array}{l}115 \\
116\end{array}$ \\
\hline Coronilla varia & $\begin{array}{l}\text { glycosides, } \\
\text { hyrcanoside and } \\
\text { deglucohyrcanoside } \\
\text { isolated from the seeds }\end{array}$ & $\begin{array}{l}\text { The Cardiotonic and cardiotoxic effects of two } \\
\text { cardiac glycosides, hyrcanoside and } \\
\text { deglucohyrcanoside isolated from the seeds of } \\
\text { Coronilla varia were evaluated in comparison } \\
\text { with the effect and toxicity of digoxin and } \\
\text { ouabain. Evaluation of the cardiotonic effect } \\
\text { using the methods of heart (in situ) and the } \\
\text { isolated heart (Langendorff) proved that } \\
\text { deglucohyrcanoside was more effective than } \\
\text { hyrcanoside and that its effect was equal to that } \\
\text { of digoxin as well as ouabain. The efficacy of } \\
\text { deglucohyrcanoside at least equal to that of } \\
\text { digoxin, while the toxicity of the former was } \\
\text { several times lower, which indicated that the } \\
\text { glycoside a potential candidate for therapeutic } \\
\text { use. }\end{array}$ & $\begin{array}{l}117- \\
120\end{array}$ \\
\hline Crocus sativus & saffron extracts & $\begin{array}{l}\text { The effect of saffron was investigated against } \\
\text { acute myocardium damage by anthracyclines } \\
\text { using rabbit heart model. The heart was } \\
\text { perfused with anthracycline, i.e. } 30 \mu \mathrm{M} \\
\text { doxorubicin (Doxo) in the presence and absence } \\
\text { of } 10 \mu \mathrm{g} / \mathrm{ml} \text { saffron extracts. Saffron perfused } \\
\text { during electrolysis helped trap ROS and } \\
\text { significantly improved myocardial function; } \\
\text { however, saffron was less effective against } \\
\text { Doxo, thus suggesting that mechanisms other } \\
\text { than oxidative stress underlie Doxo } \\
\text { cardiotoxicity. }\end{array}$ & 121 \\
\hline
\end{tabular}




\begin{tabular}{|c|c|c|c|}
\hline & $\begin{array}{lll}\text { aqueous extract and } \\
\text { safranal }\end{array}$ & $\begin{array}{l}\text { The cardioprotective effect of Crocus sativus } \\
\text { (saffron) aqueous extract and safranal, the } \\
\text { major constituent of the essential oil of saffron } \\
\text { was evaluated on lipid peroxidation, } \\
\text { biochemical parameters and histopathological } \\
\text { findings in isoproterenol (ISO)-induced } \\
\text { myocardial infarction in Wistar rats. Saffron } \\
\text { pretreatment }(20,40,80 \text { and } 160 \mathrm{mg} / \mathrm{kg} \text { ip) or } \\
\text { safranal pretreatment ( } 0.025 \text {, } 0.050 \text {, 0.075 } \\
\text { ml/kg ip) for } 8 \text { days, significantly decreased } \\
\text { (p<0.001) the serum LDH and CK-MB and } \\
\text { myocardial lipid peroxidation as compared to } \\
\text { ISO- induced rats. Histological findings of the } \\
\text { heart sections confirmed myocardial injury with } \\
\text { ISO administration and preserved nearly normal } \\
\text { tissue architecture with saffron or safranal } \\
\text { pretreatment. }\end{array}$ & 122 \\
\hline & Saffron & $\begin{array}{l}\text { The cardioprotection effect of saffron }(200,400 \\
\text { and } 800 \mathrm{mg} / \mathrm{kg}) \text { was evaluated in isoproterenol- } \\
\text { induced myocardial damage in rats. Saffron at } \\
\text { all the doses exerted significant } \\
\text { cardioprotective effect by preserving } \\
\text { hemodynamics and left ventricular functions, } \\
\text { maintaining structural integrity and augmenting } \\
\text { antioxidant status. Among the different doses } \\
\text { used, saffron at } 400 \mathrm{mg} / \mathrm{kg} \text { exhibited maximum } \\
\text { protective effects which could be due to } \\
\text { maintenance of the redox status of the cell } \\
\text { which reinforcing its role as an antioxidant. }\end{array}$ & 123 \\
\hline & $\begin{array}{l}\text { aqueous-ethanol } \\
\text { extract }\end{array}$ & 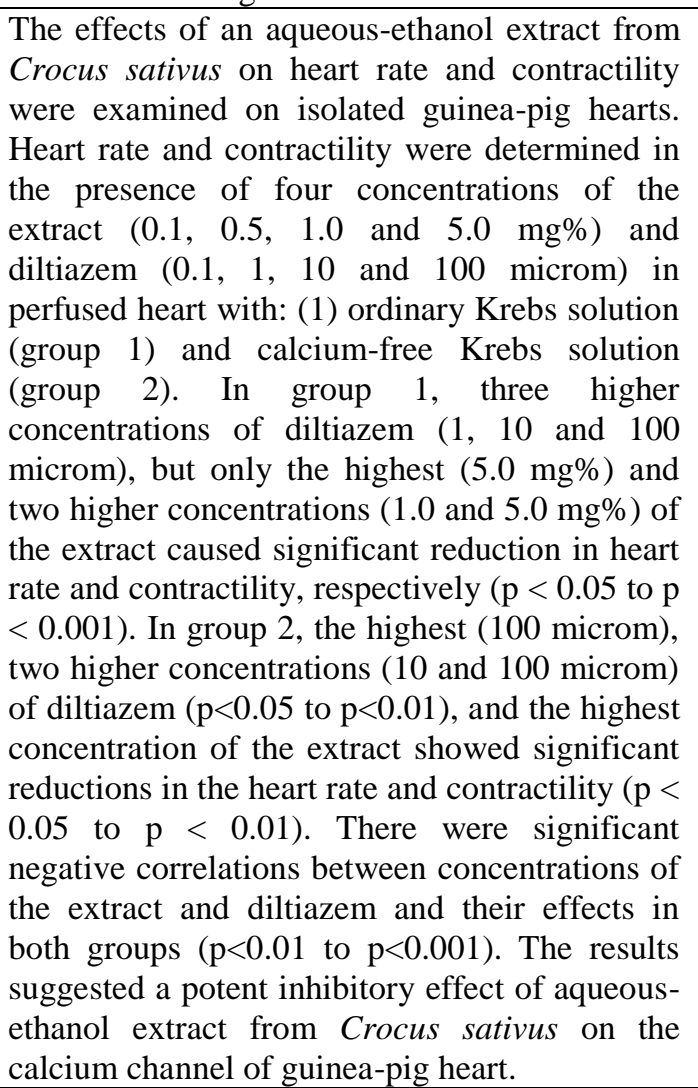 & 124 \\
\hline Cynodon dactylon & $\begin{array}{l}\text { hydroalcoholic extract } \\
\text { of rhizomes }\end{array}$ & $\begin{array}{l}\text { The effects of hydroalcoholic extract of } \\
\text { Cynodon dactylon rhizomes was evaluated on } \\
\text { cardiac contractility in normal hearts and on }\end{array}$ & 125 \\
\hline
\end{tabular}




\begin{tabular}{|c|c|c|c|}
\hline & & $\begin{array}{l}\text { cardiac functions in right-heart failure in rats. } \\
\text { Right-heart failure was induced by } \\
\text { intraperitoneal injection of monocrotaline ( } 50 \\
\mathrm{mg} / \mathrm{kg} \text { ). Two weeks later, the animals were } \\
\text { treated orally with different doses of the extract } \\
\text { for fifteen days. At the end of the experiments, } \\
\text { cardiac functions and markers of myocardial } \\
\text { hypertrophy were measured. The treated rats } \\
\text { showed very less signs of fatigue, peripheral } \\
\text { cyanosis and dyspnea. The survival rate was } \\
\text { high in the extract treated groups (90\%). } \\
\text { Administration of Cynodon dactylon in } \\
\text { monocrotaline-injected rats led to profound } \\
\text { improvement in cardiac functions as } \\
\text { demonstrated by decreased right ventricular end } \\
\text { diastolic pressure (RVEDP) and elevated mean } \\
\text { arterial pressure. RVdP/dtmax, and RVdP/dt/P } \\
\text { as indices of myocardial contractility were also } \\
\text { markedly (p<0.001) increased by the extract. } \\
\text { The extract reduced heart and lung congestion } \\
\text { by decreasing tissue wet/dry and wet/body } \\
\text { weight ratios (p<0.01). In the isolated rat hearts, } \\
\text { the extract produced a remarkable (p<0.001) } \\
\text { positive inotropic effect concomitant with a } \\
\text { parallel decrease in LVEDP. }\end{array}$ & \\
\hline & phenolic fraction & $\begin{array}{l}\text { The phenolic fraction of Cynodon dactylon } \\
\text { (CDP) was evaluated for its cardio-protective } \\
\text { activity using isolated frog's heart perfusion } \\
\text { method. The CDP produced negative inotropic } \\
\text { and chronotropic actions on isolated frog heart. } \\
\text { These pharmacological effect were selectively } \\
\text { inhibited by atropine, which indicated that these } \\
\text { effects were mediated through muscarinic } \\
\text { receptor. }\end{array}$ & 126 \\
\hline Cyperus rotundus & ethanolic extract & $\begin{array}{l}\text { The preventive role of ethanolic extract of } \\
\text { Cyperus rotundus rhizomes (CRRE) was } \\
\text { investigated on age associated changes in } \\
\text { glucose and lipids in young and aged rats. } \\
\text { CRRE was given as ( } 500 \mathrm{mg} / \mathrm{kg} \text { body weight) } \\
\text { orally for } 30 \text { days. Age associated increase in } \\
\text { serum glucose, total cholesterol, triglycerides, } \\
\text { LDL cholesterol, VLDL cholesterol and a } \\
\text { decrease in HDL cholesterol was observed in } \\
\text { aged rats compared to young rats. } \\
\text { Administration of CRRE to aged rats prevented } \\
\text { the age associated changes in glucose, total } \\
\text { cholesterol, triglycerides, LDL cholesterol and } \\
\text { VLDL cholesterol. HDL cholesterol level was } \\
\text { found to be increased significantly in both } \\
\text { young and aged rats after treatment with CRRE. }\end{array}$ & 127 \\
\hline
\end{tabular}




\begin{tabular}{|c|c|c|c|}
\hline Dalbergia sissoo & alcoholic leaf extract & $\begin{array}{l}\text { The effect of alcoholic extract } \\
\text { of Dalbergia sissoo leaf (DSE) (30, } 100 \text { and } \\
300 \mathrm{mg} / \mathrm{kg} \text { of body weight) was studied in } \\
\text { isoproterenol (ISP)-induced myocardial injury } \\
\text { in rats. Rats pretreated with DSE (30, } 100 \text { and } \\
300 \mathrm{mg} / \mathrm{kg} \text { of body weight) showed significant } \\
\text { (p<0.05-0.001) improvement in the relative } \\
\text { heart weight, myocardial infarcted areas, heart } \\
\text { rate and mean arterial pressure in ISP- } \\
\text { induced myocardial injury. DSE showed } \\
\text { significant (p < 0.05-0.001) improvement in } \\
\text { serum LDH, CK-MB, cholesterol, LDL and } \\
\text { triglyceride levels at all the dose levels. } \\
\text { However, DSE pretreatment had no significant } \\
\text { effect on serum HDL level. Pretreatment with } \\
\text { DSE (30, } 100 \text { and } 300 \text { mg/kg body weight) } \\
\text { showed significant (p < 0.001) reduction in } \\
\text { MDA level in comparison with myocardial } \\
\text { injured rats. Furthermore, antioxidant potential } \\
\text { was also improved in terms of improved } \\
\text { activities of reduced glutathione, superoxide } \\
\text { dismutase and catalase with the DSE } \\
\text { pretreatment. Histopathology also showed } \\
\text { significant improvement in heart tissue. }\end{array}$ & $\begin{array}{l}128- \\
129\end{array}$ \\
\hline Daucus carota & $\begin{array}{l}\text { aqueous extract of } \\
\text { tubers }\end{array}$ & $\begin{array}{l}\text { Aqueous extract of Daucus carota tubers were } \\
\text { investigated for inotropic and cardioprotective } \\
\text { effects by measuring various biochemical } \\
\text { parameters at the test doses of } 250 \text { and } 500 \\
\mathrm{mg} / \mathrm{kg} \text {. Isoproterenol }(5.25 \mathrm{mg} / \mathrm{kg} \text { and } 8.5 \\
\mathrm{mg} / \mathrm{kg} \text { ) was administered subcutaneously on } \\
29^{\text {th }} \text { and } 30^{\text {th }} \text { day respectively in order to induce } \\
\text { myocardial infarction. Cardiac tonicity was } \\
\text { estimated by evaluating } \mathrm{Na}^{+} \mathrm{K}^{+} \mathrm{ATPase} \text {, } \\
\mathrm{Mg}^{2+} \mathrm{ATPase} \text { and } \mathrm{Ca}^{2+} \mathrm{ATPase} \mathrm{evels}^{+} \text {in heart. } \\
\mathrm{The} \text { levels of } \mathrm{Na}^{+} \mathrm{K}^{+} \mathrm{ATPase} \text { and } \mathrm{Mg}^{2+} \mathrm{ATPase} \\
\text { were decreased and that of } \mathrm{Ca}^{2+} \mathrm{ATPase}^{\mathrm{T}} \text { was } \\
\text { increased in extract-treated group significantly } \\
\text { (p<0.001). Cardioprotection was assessed by } \\
\text { estimating serum aspartate transaminase, } \\
\text { alanine transaminase, lipid peroxidase, and } \\
\text { lactate dehydrogenase levels and cardiac total } \\
\text { protein and lipid peroxidase, and lactate } \\
\text { dehydrogenase. The levels altered by } \\
\text { isoproterenol were restored significantly by the } \\
\text { administration of the extract. }\end{array}$ & 130 \\
\hline $\begin{array}{l}\text { Digitalis lanata and } \\
\text { Digitalis purpurea }\end{array}$ & digitalis glycosides & $\begin{array}{l}\text { Cardiac glycosides, are often called digitalis or } \\
\text { digitalis glycosides, in particular digoxin and } \\
\text { digitoxin, have been a cornerstone of the } \\
\text { treatment of heart diseases for more than two } \\
\text { centuries. They possessed many cardiovascular } \\
\text { effects: (I)Regulation of cytosolic calcium } \\
\text { concentration: by inhibiting the } \mathrm{Na}^{+} / \mathrm{K}^{+}- \\
\text {adenosine triphosphatase (ATPase) enzyme, } \\
\text { thereby increasing cardiac contractility. (II) } \\
\text { Increased contractility of the cardiac muscle: } \\
\text { causing cardiac output to more closely resemble } \\
\text { that of the normal heart. Vagal tone is also } \\
\text { enhanced, so both heart rate and myocardial } \\
\text { oxygen demand decrease. Digitalis slows }\end{array}$ & $\begin{array}{l}131- \\
138\end{array}$ \\
\hline
\end{tabular}




\begin{tabular}{|c|c|c|c|}
\hline & & $\begin{array}{l}\text { conduction velocity through the AV node, } \\
\text { making it useful for atrial fibrillation. (III) } \\
\text { Electrophysiological effects: the major effect on } \\
\text { cardiac rhythm of digitalis preparations is } \\
\text { believed to be due to inhibition of the sodium } \\
\text { pump. However, cells in various parts of the } \\
\text { heart show differing sensitivities to digitalis, } \\
\text { and both direct and neurally mediated effects } \\
\text { are now known to occur. Indeed, at therapeutic } \\
\text { levels of digitalis, these drugs decrease } \\
\text { automaticity and increase maximum diastolic } \\
\text { potential, effects that can be blocked by } \\
\text { atropine, whereas higher (toxic) concentrations } \\
\text { decrease diastolic potentials and increase } \\
\text { automaticity. Similarly, the toxic } \\
\text { arrhythmogenic effects of the cardiac } \\
\text { glycosides are due to a combination of direct } \\
\text { effects on the myocardium and neurally } \\
\text { mediated increases in autonomic activity. }\end{array}$ & \\
\hline $\begin{array}{l}\text { Ephedra alata and } \\
\text { Epedra foliata }\end{array}$ & Ephedrine & $\begin{array}{l}\text { The arterial pressure, raised and vagal slowing } \\
\text { occurred after administration of ephedrine to } \\
\text { experimental animals. It appeared that } \\
\text { ephedrine activates the same adrenergic } \\
\text { receptors as epinephrine but is less potent and } \\
\text { has a longer duration of action. The pressor } \\
\text { response to ephedrine is due in part to } \\
\text { peripheral constriction and in part to myocardial } \\
\text { stimulation. In humans, ephedrine increases the } \\
\text { arterial pressure both by peripheral } \\
\text { vasoconstriction and by cardiac stimulation. } \\
\text { The heart rate is usually increased, as is the } \\
\text { pulse pressure, both suggesting an increased } \\
\text { cardiac output. However, the hypotension that } \\
\text { commonly occurs during surgery under spinal } \\
\text { anesthesia is practically always prevented by } \\
\text { ephedrine. As a conclusion, it appeared that } \\
\text { ephedrine activates the same adrenergic } \\
\text { receptors as epinephrine but is less potent and } \\
\text { has a longer duration of action. In complete } \\
\text { heart block with Stokes-Adams syncope, } \\
\text { ephedrine proved of value to increase } \\
\text { ventricular rate and prevent ventricular asystole, } \\
\text { an initial dose of about } 8 \text { mg of ephedrine } \\
\text { sulfate orally may be tried, then the dose } \\
\text { increased to } 25 \text { mg three or four times daily. } \\
\text { Syncope due to ventricular tachycardia can also } \\
\text { be prevented in some cases with ephedrine. }\end{array}$ & $\begin{array}{l}139- \\
141\end{array}$ \\
\hline Erodium cicutarium & organic extracts & $\begin{array}{l}\text { The addition of extracts of Erodium cicutarium } \\
\text { to the Kreb's solution perfusing isolated heart } \\
\text { from rabbit, they produced a negative } \\
\text { ionotropic action. Organic extracts (hexane and } \\
\text { methanol) having a greater activity on smooth } \\
\text { and cardiac muscles than water extracts. }\end{array}$ & $\begin{array}{l}142- \\
145\end{array}$ \\
\hline
\end{tabular}

Plants with anti-arrhythmic effects: 


\begin{tabular}{|c|c|c|c|}
\hline Plant & The tested constituent & Activity. & Ref \\
\hline Achillea santolina & methanol extract & $\begin{array}{l}\text { On isolated heart of rats as an experimental model } \\
\text { to determine the effect of the methanol extract of } \\
\text { Achillea santolina on the electro physiological } \\
\text { properties, the methanolic extract of Achillea } \\
\text { santolina induced significant depression of } \\
\text { WBCL, AVCT and ERP and non-significant } \\
\text { increase in the time constant of recovery (t.rec). It } \\
\text { may be considered a potential drug for anti- } \\
\text { arrhythmic effect for suppression or treating } \\
\text { supraventricular tachyarrhythmia. }\end{array}$ & 146 \\
\hline Ammi visnaga & $\begin{array}{l}\text { visnadin, } \\
\text { dihydrosamidin, } \\
\text { khellin and samidin }\end{array}$ & $\begin{array}{l}\text { In coronary vasospasm and myocardial ischaemia } \\
\text { induced in dogs by daily intramuscular injections } \\
\text { of vasopressin, visnadin, dihydrosamidin, khellin } \\
\text { and samidin effectively normalized the } \\
\text { electrocardiogram when given in a dose of } 4.7 \\
\text { mg/kg bw per day intramuscularly for } 7 \text { days. }\end{array}$ & $\begin{array}{l}78, \\
147\end{array}$ \\
\hline $\begin{array}{l}\text { Carthamus } \\
\text { tinctorius }\end{array}$ & $\begin{array}{l}\text { Carthamus tinctorius } \\
\text { aqueous injection }\end{array}$ & $\begin{array}{l}\text { Carthamus tinctorius injection( CTI }(2.5 \text { and } \\
0.625 \mathrm{~g} / \mathrm{kg}) \text { significantly inhibited the typical ECG } \\
\mathrm{S}-\mathrm{T} \text { segment elevation, reduced concentration of } \\
\text { IL-6 and TNF- } \alpha \text { in serum, suppressed } \\
\text { overexpression of Bax protein and also inhibited } \\
\text { the reduction of } \mathrm{BCl}-2 \text { expression and markedly } \\
\text { depressed the Bax/Bcl- } 2 \text { ratio in isoprenaline- } \\
\text { induced acute myocardial ischemia (AMI). These } \\
\text { findings demonstrate that CTI is cardioprotective } \\
\text { against AMI in rats and is likely to related to } \\
\text { decrease inflammatory response mediated by TNF- } \\
\alpha \text { and IL- } 6 \text {, down-regulate protein level of Bax and } \\
\text { up-regulate that of Bcl- } 2 \text { in the heart tissue. }\end{array}$ & $\begin{array}{l}95 \\
148\end{array}$ \\
\hline Cichorium intybus & $\begin{array}{lll}\text { roots extracts of } \\
\text { different varieties of } \\
\text { the plant }\end{array}$ & $\begin{array}{l}\text { Pharmacological study of eight varieties of } \\
\text { Cichorium intybus on isolated toad's heart showed } \\
\text { that the eight varieties have a quinidine like action, } \\
\text { but with variable potency. }\end{array}$ & 149 \\
\hline \multirow[t]{2}{*}{ Crocus sativus } & hydroalcohol extract & $\begin{array}{l}\text { The effects of aqueous-ethanolic extract } \\
\text { from Crocus sativus }(0.1,0.5,1.0 \text { and } 5.0 \mathrm{mg} \%) \\
\text { were investigated on heart rate and contractility of } \\
\text { guinea-pig isolated heart. Only highest and two } \\
\text { larger concentrations of the extract caused } \\
\text { significant reduction in heart rate and heart } \\
\text { contractility respectively ( }<<0.05 \text { to } \mathrm{P}<0.01) \text {. There } \\
\text { were significant negative correlation between } \\
\text { concentrations of the extract and diltiazem and } \\
\text { their effect on heart rate and contractility in both } \\
\text { groups }(\mathrm{p}<0.01 \text { to } \mathrm{p}<0.001) \text {. }\end{array}$ & 150 \\
\hline & saffron & $\begin{array}{l}\text { High dose }(200 \mathrm{mg} / \mathrm{kg}) \text { of saffron significantly } \\
\text { increased the PR interval, P duration, QT interval } \\
(\mathrm{p}<0.01) \text {, QRS interval, QTcn (normalized } \\
\text { corrected QT) }(\mathrm{p}<0.001) \text {, and JT interval }(\mathrm{p}<0.05) \\
\text { of ECG compared to the control group. In addition, } \\
\text { the two other doses only significantly prolonged } \\
\text { the QT, QTcn and JT intervals of ECG versus the } \\
\text { control group. The SAF } 200 \text { group also showed a } \\
\text { notable increase in RR interval which only was } \\
\text { significant compared to the SAF50. There was no } \\
\text { significant difference among ST height and T } \\
\text { amplitude ranges of different groups. Accordingly, } \\
\text { the results revealed that high dose of saffron }\end{array}$ & 151 \\
\hline
\end{tabular}




\begin{tabular}{|c|c|c|c|}
\hline & & $\begin{array}{l}\text { definitely slowed the electrical conduction velocity } \\
\text { in both atrium and ventricle. }\end{array}$ & \\
\hline Cynodon dactylon & $\begin{array}{l}\text { hydroalcoholic } \\
\text { extract of rhizome }\end{array}$ & 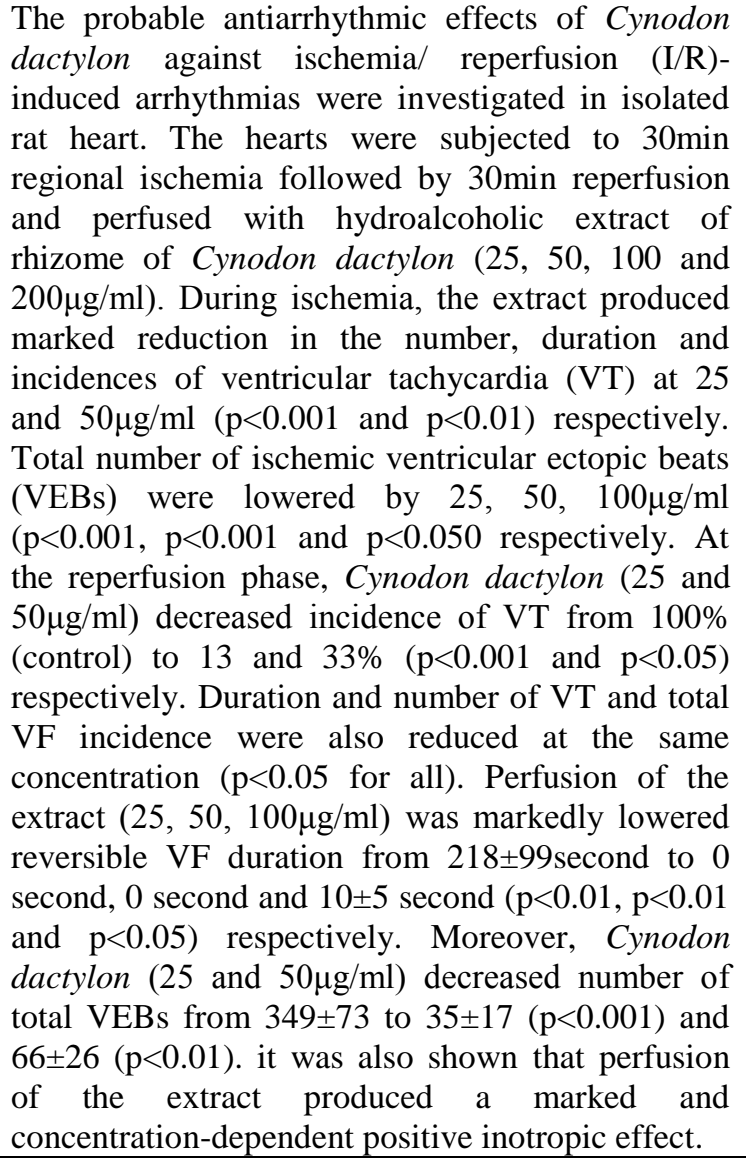 & 152 \\
\hline
\end{tabular}

Plants with hypolipidemic effects:

\begin{tabular}{|c|c|c|c|}
\hline Plant & $\begin{array}{l}\text { The tested } \\
\text { constituent }\end{array}$ & Activity & Ref \\
\hline Allium species & $\begin{array}{l}\text { Garlic }(1-4 \% \text { in } \\
\text { diet }) \text { different } \\
\text { extracts }\end{array}$ & $\begin{array}{l}\text { Garlic (1-4\% in diet) and garlic protein } \\
\text { administration in hypercholesterolemic rats } \\
\text { induced by a high-cholesterol diet, } \\
\text { significantly reduced serum cholesterol, } \\
\text { triglyceride and LDL cholesterol. Long term } \\
\text { feeding of garlic and garlic preparations on } \\
\text { experimental atherosclerosis induced by a } \\
\text { high-cholesterol diet in rabbits cause } \\
\text { statistically significant reduction in serum } \\
\text { lipids and atheromatous lesions. Water soluble } \\
\text { extract of garlic inhibited the biosynthesis of } \\
\text { cholesterol in hepatocytes. Garlic derived } \\
\text { components are capable of mbining with the } \\
\text { sulphydryl (-SH) group. Reduced conversion } \\
\text { of acetate into cholesterol has been observed } \\
\text { both in vivo and in vitro. Eating of } 10 \mathrm{~g} \text { fresh } \\
\text { garlic per day for } 2 \text { months significantly } \\
\text { decreases (15\%-28.5\%) serum cholesterol } \\
\text { levels among hypercholesterolemic patients. } \\
\text { Garlic oil caused a steady decrease in LDL } \\
\text { and VLDL levels with concomitant increase in } \\
\text { HDL levels. Intake of enteric-coated garlic }\end{array}$ & $\begin{array}{l}153- \\
172\end{array}$ \\
\hline
\end{tabular}




\begin{tabular}{|c|c|c|c|}
\hline & & $\begin{array}{l}\text { powder (equal to } 400 \mathrm{mg} \text { garlic, } 1 \mathrm{mg} \text { allicin) } \\
\text { twice daily in hyperlipidemic patients has } \\
\text { significantly reduced total cholesterol, LDL- } \\
\text { cholesterol and triglyceride and increased } \\
\text { HDL-cholesterol. The level of cholesterol, } \\
\text { triglyceride, phospholipids and ß- lipoproteins } \\
\text { were significantly declined in the individuals } \\
\text { consuming 10-50 g of garlic /week. These } \\
\text { results indicate that routine consumption of } \\
\text { garlic in the diet has a beneficial effect in } \\
\text { maintaining the serum lipids at low or normal } \\
\text { levels. In a placebo-controlled trial of patients } \\
\text { with stage II peripheral arterial occlusive } \\
\text { disease, garlic powder supplements, } 800 \mathrm{mg} \\
\text { daily were associated with a significant } \\
\text { increase in walking distance by } 46 \text { meters; the } \\
\text { improvement started after the fifth week of } \\
\text { treatment. Patients treated with } 900 \text { mg daily } \\
\text { of standardized garlic powder showed } 9-18 \% \\
\text { reduction in plaque volume, a } 4 \% \text { decrease in } \\
\text { LDL levels, an } 8 \% \text { increase in HDL } \\
\text { concentrations, and a } 7 \% \text { decrease in blood } \\
\text { pressure. }\end{array}$ & \\
\hline \multirow[t]{2}{*}{ Aloe vera } & Aloe vera gel & $\begin{array}{l}\text { Aloe vera gel lowered triacylglyceride levels } \\
\text { in liver and plasma. Histological examinations } \\
\text { of periepididymal fat pad showed that Aloe } \\
\text { vera gel reduced the average size of } \\
\text { adipocytes. }\end{array}$ & $\begin{array}{l}173- \\
174\end{array}$ \\
\hline & Aloe vera in diet & $\begin{array}{l}\text { Five thousand patients of atheromatous heart } \\
\text { disease, presented as angina pectoris, were } \\
\text { studied over a period of five years. After } \\
\text { adding the (Husk of Isabgol) and (Aloe vera) } \\
\text { to the diet, a marked reduction in total serum } \\
\text { cholesterol, serum triglycerides, increased } \\
\text { HDL, decreased fasting and postprandial } \\
\text { blood sugar level in diabetic patients were } \\
\text { noted. Simultaneously the clinical profile of } \\
\text { these patients showed reduction in the } \\
\text { frequency of anginal attacks. }\end{array}$ & 175 \\
\hline Alpinia galangal & $\begin{array}{l}\text { ethanolic extract } \\
\text { and constituents }\end{array}$ & $\begin{array}{l}\text { Ethanolic extract of } A \text {. galanga } 20 \mathrm{mg} / \text { day for } \\
4 \text { weeks in rats exerted hypolipidemic activity, } \\
\text { with a significant increase in the serum levels } \\
\text { of high density lipoproteins (HDL) in rats. } A \text {. } \\
\text { galanga constituents exerted platelet } \\
\text { activating factor (PAF) antagonists. } \\
\text { Methanolic extract showed significant } \\
\text { inhibitory effects on PAF with IC50 value of } \\
5.5 \mathrm{ug} / \mathrm{ml} \text { in rabbit platelets. }\end{array}$ & $\begin{array}{l}176- \\
178\end{array}$ \\
\hline Ammi visnaga & khellin & $\begin{array}{l}\text { A clinical study was carried out on } 20 \text { non- } \\
\text { obese, normolipaemic male subjects to } \\
\text { determine the effects of orally administered } 50 \\
\text { mg khellin four times daily for } 4 \text { weeks on the } \\
\text { plasma lipids. Plasma total cholesterol and } \\
\text { triglyceride remained unchanged, but high- } \\
\text { density-lipoprotein cholesterol concentration } \\
\text { was significantly elevated during the } \\
\text { treatment and till one week after cessation of } \\
\text { treatment. In a comparison with glyceryl } \\
\text { trinitrate, khellin } 3 \text { ml containing } 150 \text { mg of }\end{array}$ & 179 \\
\hline
\end{tabular}




\begin{tabular}{|c|c|c|c|}
\hline & & $\begin{array}{l}\text { khellin, alcoholic extract standardized to } \\
\text { contain } 50 \mathrm{mg} / \mathrm{ml} \text { ) was used in twelve patients } \\
\text { for prevention of angina of effort and the } \\
\text { electrocardiographic changes that may } \\
\text { accompany it. Khellin was less potent but } \\
\text { longer acting than glyceryl trinitrate, and it } \\
\text { did not cause any unpleasant side effects. }\end{array}$ & \\
\hline \multirow[t]{2}{*}{ Anethum graveolens } & crude extract & $\begin{array}{l}\text { The crude extract of Anethum graveolens } \\
\text { showed anti-hyper cholesterolaemic and anti- } \\
\text { hyperlipidaemic activities. The crude extracts } \\
\text { of } A \text {. graveolens L. besides having strong anti- } \\
\text { hyperlipidaemic effects, it improved the } \\
\text { biological antioxidant status by reducing lipid } \\
\text { peroxidation in liver and modulating the } \\
\text { activities of antioxidant enzymes in rats fed } \\
\text { with high fat. }\end{array}$ & $\begin{array}{l}180- \\
181\end{array}$ \\
\hline & $\begin{array}{l}\text { defatted } \\
\text { ethanolic extract }\end{array}$ & $\begin{array}{l}\text { Treatment of hyperlipidaemic rats with } \\
\text { defatted ethanolic Anethum graveolens extract } \\
\text { (single daily dose of } 1 \mathrm{ml} \text {, equivalent to } 500 \\
\text { mg of the plant powder) and high-fat diet for } \\
\text { up to } 10 \text { and/or } 30 \text { days reversed the serum } \\
\text { lipid levels compared to rats which were fed } \\
\text { only high-fat diet. In addition, it induced } \\
\text { significant increase in HMG-CoA/mevalonate } \\
\text { ratio as compared to rats which were fed high- } \\
\text { fat diet after treatment with defatted ethanolic } \\
\text { Anethum graveolens } L \text {. extract for } 30 \text { days. }\end{array}$ & $\begin{array}{l}182- \\
183\end{array}$ \\
\hline \multirow[t]{2}{*}{ Apium graveolens } & $\begin{array}{l}\text { different extracts } \\
\text { of different parts } \\
\text { and } 3-\mathrm{N}- \\
\text { butylphthalide } \\
\text { islated from the } \\
\text { plant }\end{array}$ & $\begin{array}{l}\text { Many experimental studies showed that } \\
\text { Apium graveolens significant lowered serum } \\
\text { total cholesterol, triglycerides, LDL and } \\
\text { VLDL and increased HDL level. Apium } \\
\text { graveolens also reduced the formation of } \\
\text { arterial plaques in experimental studies. } \\
\text { However, the mechanisms suggested for lipid } \\
\text { lowering action of Apium graveolens } \\
\text { including inhibition of hepatic cholesterol } \\
\text { biosynthesis, increasing faecal bile acid } \\
\text { excretion and enhancing plasma lecithin: } \\
\text { cholesterol acyltransferase activity and } \\
\text { reduction of lipid absorption in the intestine. } \\
\text { Some authors mentioned that blood lipids } \\
\text { lowering effects was attributed to the } \\
\text { compound 3n butylphthalideor (3nB) isolated } \\
\text { from Apium graveolens, but, the active extract } \\
\text { free from 3-n-butylphthalide has been } \\
\text { reported to have lipid-lowering action. } \\
\text { Instead, thin layer chromatography indicated } \\
\text { that polar compounds with sugar or amino } \\
\text { acid side chains(s) could be the } \\
\text { hypocholesterolaemic constituents of celery } \\
\text { extract. }\end{array}$ & $\begin{array}{l}184- \\
188\end{array}$ \\
\hline & $\begin{array}{l}\text { ethanolic extract } \\
\text { of seeds }\end{array}$ & $\begin{array}{l}\text { In evaluation of the protective effects of } \\
\text { ethanolic extract of Apium graveolens on } \\
\text { ritonavir (a protease inhibitor) - induced } \\
\text { dyslipidemia. It appeared that concurrent } \\
\text { treatment with high dose of ethanolic extract } \\
\text { of Apium graveolens }(150 \mathrm{mg} / \mathrm{kg}) \text { in mice with } \\
\text { ritonavir, showed significant improvement in } \\
\text { blood lipid profile. However, using of low }\end{array}$ & 189 \\
\hline
\end{tabular}




\begin{tabular}{|c|c|c|c|}
\hline & & $\begin{array}{l}\text { dose of ethanolic extract of Apium graveolens } \\
(75 \mathrm{mg} / \mathrm{kg}) \text { showed no significant effects. }\end{array}$ & \\
\hline \multirow[t]{4}{*}{ Arachis hypogaea } & $\begin{array}{l}\text { soluble } \\
\text { polyphenolic } \\
\text { extract }\end{array}$ & $\begin{array}{l}\text { The effect of water soluble polyphenolic } \\
\text { extract of peanut skin (PE) was investigated } \\
\text { for its hypolipidemic properties and } \\
\text { improvement of lipid homoeostasis in rats. } \\
300 \mathrm{mg} / \mathrm{kg} \text { body weight of ( PE ) significantly } \\
\text { reduced body weight and epididymal fat. } \\
\text { Plasma and liver triglyceride (TG) and } \\
\text { cholesterol (TC) levels were also significantly } \\
\text { reduced, and the faecal secretion of TG and } \\
\text { TC was greatly increased upon PE } \\
\text { administration. Liver mRNA expression of } \\
\text { enzymes involved in fatty acid synthesis, such } \\
\text { as fatty acid synthase (FAS), sterol receptor } \\
\text { element binding protein (SREBP)-1c, acetyl- } \\
\text { CoA carboxylase (ACC1) and lipid uptake } \\
\text { genes, such as PPAR } \gamma, \text { were decreased, while } \\
\text { PPAR } \alpha \text { was up-regulated by administration of } \\
\text { PE. }\end{array}$ & $\begin{array}{l}190- \\
191\end{array}$ \\
\hline & $\begin{array}{l}\text { water-soluble } \\
\text { peanut skin } \\
\text { polyphenol } \\
\text { fraction }\end{array}$ & $\begin{array}{l}\text { Feeding a high-cholesterol diet with a water- } \\
\text { soluble peanut skin polyphenol fraction to rats } \\
\text { reduced their plasma cholesterol level, with an } \\
\text { increase in fecal cholesterol excretion. The } \\
\text { hypocholesterolemic effect was greater with } \\
\text { the lower-molecular-weight rather than } \\
\text { higher- molecular-weight polyphenol fraction. } \\
\text { This effect attributed to some oligomeric } \\
\text { polyphenols which reduced the solubility of } \\
\text { dietary cholesterol in intestinal bile acid- } \\
\text { emulsified micelles. }\end{array}$ & 192 \\
\hline & $\begin{array}{l}\text { peanut } \\
\text { consumption }\end{array}$ & $\begin{array}{l}\text { The effects of peanut (Arachis hypogaea) } \\
\text { consumption on oxidant-antioxidant status and } \\
\text { lipid profile in Streptozotocin (STZ) induced } \\
\text { diabetic rats was investigated. Rats were given } \\
\text { standard rat chow supplemented with } 0.63 \mathrm{~g} \\
\% \text { peanut for } 12 \text { weeks. The supplementation } \\
\text { with peanut in the diabetic group led to } \\
\text { significantly higher HDL-C levels and lower } \\
\text { atherogenic index (AI) levels compared to } \\
\text { diabetic group. Peanut consumption increased } \\
\text { GSH levels significantly both in control and } \\
\text { diabetic groups. }\end{array}$ & 193 \\
\hline & $\begin{array}{l}\text { peanet } \\
\text { stilbenoids }\end{array}$ & $\begin{array}{l}\text { Most of peanet stilbenoids inhibited } \\
\text { intracellular generation of reactive oxygen } \\
\text { species (ROS) in PMA inducedHL-60 cells. } \\
\text { Three stilbenids compounds produced a } \\
\text { strongest antioxidant effect. Twelve } \\
\text { compounds demonstrated significantly high } \\
\text { antioxidant properties which were comparable } \\
\text { to those of Trolox. Although, the majority of } \\
\text { stilbenoids demonstrated moderate cytoxicity } \\
\text { toward HL-60 cells, but the antioxidant effect } \\
\text { was observed at much lower concentrations } \\
\text { which confirmed that the antioxidant effect } \\
\text { was not related to cytotoxic effect. }\end{array}$ & $\begin{array}{l}194- \\
195\end{array}$ \\
\hline Asparagus officinalis & butanol extract & $\begin{array}{l}\text { The hypolipidemic effect of } n \text {-butanol extract } \\
\text { from asparagus by-products was evaluated in } \\
\text { mice fed a high-fat diet. Asparagus butanol }\end{array}$ & $\begin{array}{l}196- \\
198\end{array}$ \\
\hline
\end{tabular}




\begin{tabular}{|c|c|c|c|}
\hline & & $\begin{array}{l}\text { extract significantly decreased the levels of } \\
\text { body weight gain, serum total cholesterol and } \\
\text { low density lipoprotein cholesterol; it } \\
\text { dramatically increased the high density } \\
\text { lipoprotein level when administered at three } \\
\text { different doses ( } 40,80 \text { or } 160 \mathrm{mg} / \mathrm{kg} \text { body } \\
\text { weight) for } 8 \text { weeks in hyperlipidemic mice. } \\
\text { In addition, asparagus butanol extract } \\
\text { decreased the levels of alanine transaminase, } \\
\text { aspartate transaminase and alkaline } \\
\text { phosphatase in serum. Superoxide dismutase } \\
\text { activity and the total antioxidation capacity } \\
\text { were evidently increased; in addition, the } \\
\text { malondialdehyde level and the distribution of } \\
\text { lipid droplets were reduced in liver cells of } \\
\text { asparagus butanol extract- treated mice. }\end{array}$ & \\
\hline \multirow[t]{4}{*}{ Avena sativa } & Oat $\beta$-glucan & $\begin{array}{l}\text { Oat } \beta \text {-glucan exerted cholesterol-lowering } \\
\text { properties. The consumption of oat meal and } \\
\text { oat bran reduced total plasma cholesterol and } \\
\text { LDL-cholesterol levels. This effect attributed } \\
\text { to } \beta \text {-glucan, it interfered with the reabsorption } \\
\text { of bile acid in the gut and reduces cholesterol } \\
\text { levels The oat bran has been found to be the } \\
\text { only fiber source that significantly lowered } \\
\text { total and low density-lipoprotein cholesterol } \\
\text { levels in mild hypercholesterolemics. }\end{array}$ & $\begin{array}{l}199- \\
200\end{array}$ \\
\hline & oat bran & $\begin{array}{l}\text { C57BL/6 NCrl mice responded to oat bran } \\
\text { with } 19 \pm 1 \%(\mathrm{P}<0.001) \text { lower plasma } \\
\text { cholesterol, } 40 \pm 5 \%(\mathrm{P}<0.01) \text { higher } \\
\text { excretion of bile acids and increased } \\
\text { expression of the bile acid-producing hepatic } \\
\text { enzymes CYP7A1 and CYP8B1, but none of } \\
\text { these effects were found in control } \\
\text { C57BL/6JBomTac mice. }\end{array}$ & 201 \\
\hline & oat $\beta$-glucan & $\begin{array}{l}\text { To explored the dose-dependent effect of oat } \\
\text { cereal } \beta \text {-glucan on improving metabolic } \\
\text { indexes of obesity mice, C57-Bl mice were } \\
\text { randomized to chow diet (N) group and high } \\
\text { fat diet group and other three doses of oat } \beta \text { - } \\
\text { glucan groups (low } \beta \text {-glucan, medium } \beta \text { - } \\
\text { glucan, and high } \beta \text {-glucan). Energy intake, } \\
\text { glucose, lipids, and appetite related hormones } \\
\text { were tested. Dose-dependent relation was } \\
\text { observed on oat } \beta \text {-glucan doses and body } \\
\text { weight change, average energy intake, total } \\
\text { cholesterol, HDL cholesterol, plasma neural } \\
\text { peptide Y, arcuate neural peptide Y mRNA, } \\
\text { and arcuate neural peptide Y receptor } 2 \\
\text { mRNA level. Oat } \beta \text {-glucan helped to increase } \\
\text { plasma peptide Y-Y and intestine peptide Y-Y } \\
\text { expression in obesity mice. }\end{array}$ & 202 \\
\hline & oat $\beta$-glucan & $\begin{array}{l}\text { The United States Food and Drug } \\
\text { Administration (FDA) approved a health } \\
\text { claim for } \beta \text {-glucan soluble fiber from oats for } \\
\text { reducing plasma cholesterol levels and risk of } \\
\text { heart disease in 1997. Similarly, in } 2004 \text { the } \\
\text { United Kingdom Joint Health Claims } \\
\text { Initiative (JHCI) allowed a cholesterol- } \\
\text { lowering health claim for oat } \beta \text {-glucan. }\end{array}$ & 30,203 \\
\hline
\end{tabular}




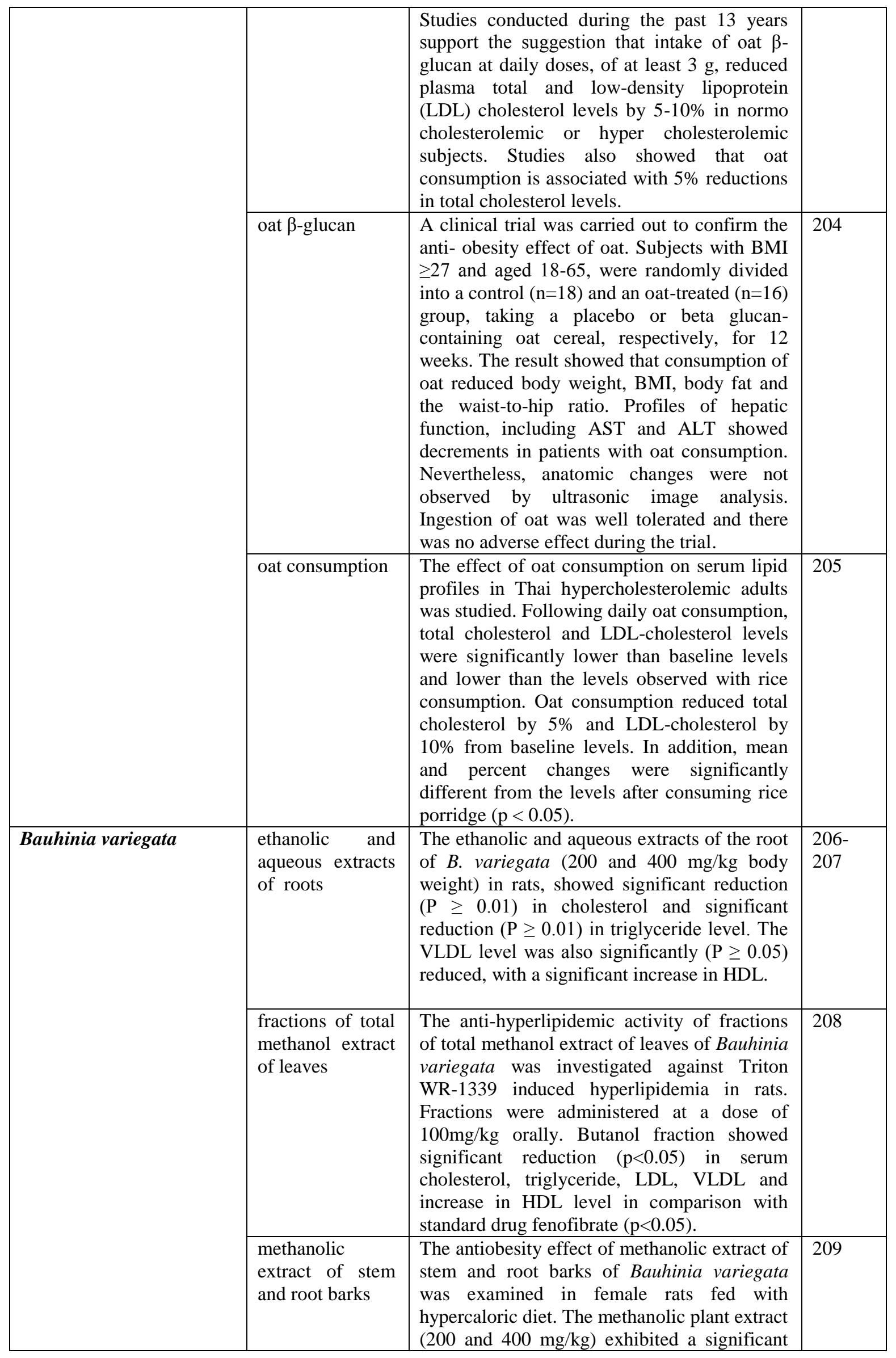




\begin{tabular}{|c|c|c|c|}
\hline & & $\begin{array}{l}\text { hypolipidemic effect with a reduction in the } \\
\text { feed intake and body weight. Treatment of } \\
\text { obese animals with the methanolic extract of } \\
B \text {. variegate exhibited an increased brain } \\
\text { serotonin level and high density lipoprotein } \\
\text { with a concomitant decrease in total } \\
\text { cholesterol, triglycerides and low density } \\
\text { lipoprotein. Thus the antiobesity activity of } \\
\text { methanolic extract of } B \text {. variegata could be } \\
\text { attributed to tendency of the extract to reduce } \\
\text { lipid profile and elicit the brain serotonin } \\
\text { level. }\end{array}$ & \\
\hline Bellis perennis & $\begin{array}{l}\text { methanolic } \\
\text { extract and its } \\
\text { saponin fraction } \\
\text { (methanol-eluted } \\
\text { fraction) of the } \\
\text { flowers }\end{array}$ & $\begin{array}{l}\text { The methanolic extract and its saponin } \\
\text { fraction (methanol-eluted fraction) of the } \\
\text { flowers of Bellis perennis were found to } \\
\text { suppress serum triglyceride elevation in olive } \\
\text { oil-treated mice. Among these saponins, } \\
\text { perennisosides I and II showed inhibitory } \\
\text { effects on serum triglyceride elevation at } \\
\text { doses of } 25-50 \mathrm{mg} / \mathrm{kg} \text { orally. As a result of } \\
\text { hypolipidemic effect of saponin constituents } \\
\text { isolated from the flowers of Bellis perennis, it } \\
\text { also can be utilize as preventive drug in } \\
\text { ischemic diseases and as an anti-obese } \\
\text { remedy. }\end{array}$ & $\begin{array}{l}210- \\
212\end{array}$ \\
\hline Benincasa hispida & $\begin{array}{l}\text { ash gourd } \\
\text { (Benincasa } \\
\text { hispida) }\end{array}$ & $\begin{array}{l}\text { Salad prepared by using 100gm of ash gourd } \\
\text { (Benincasa hispida) and one gram of curry } \\
\text { leaves ( } 10 \text { curry leaves) and five grams of } \\
\text { skimmed milk powder (made into curd) and } \\
\text { pepper and salt are added for taste. This salad } \\
\text { was freshly prepared every day and given to } \\
\text { hyperlipidemic diabetic patients in mid } \\
\text { morning for a period of three months to find } \\
\text { out the therapeutic effect of supplementation } \\
\text { of ash gourd and curry leaves. } \\
\text { Supplementation of ash gourd and curry } \\
\text { leaves had significant hypoglycemic and } \\
\text { hypolidemic effect and it reduced the blood } \\
\text { glucose level (both fasting and post prandial), } \\
\text { within the period of three months. }\end{array}$ & $\begin{array}{l}213- \\
214\end{array}$ \\
\hline \multirow[t]{3}{*}{ Brassica rapa } & $\begin{array}{l}\text { ethanol extract of } \\
\text { root }\end{array}$ & $\begin{array}{l}\text { The effect of different doses ethanol extract of } \\
\text { root on blood lipid changes was studied in } \\
\text { hypercholesterolemic rabbits. Extract was } \\
\text { given in as } 100,200,400 \mathrm{mg} / \mathrm{kg} \text { body weight } \\
\text { of the rabbits. The results showed that the } \\
\text { turnip root extract can prevent the occurrence } \\
\text { of atherosclerotic in hypercholesterolemic } \\
\text { rabbits which may be due to flavonoids and } \\
\text { vitamins contents. }\end{array}$ & 215 \\
\hline & $\begin{array}{l}\text { Caulilexin } \mathrm{C} \text {, } \\
\text { indoleacetonitrile } \\
\text { and arvelexin } \\
\text { isolated from the } \\
\text { root }\end{array}$ & $\begin{array}{l}\text { Caulilexin C, indoleacetonitrile and arvelexin } \\
\text { isolated from the root of Brassica rapa (at a } \\
\text { concentration of } 100 \mu \mathrm{g} / \mathrm{ml} \text { ) showed an } \\
\text { inhibitory activity on human Acyl CoA: } \\
\text { cholesterol transferase } 1 \text { (hACAT1) by } \\
54.6 \pm 6.0 \%, 69.2 \pm 4.7 \% \text { and } 68.6 \pm 3.7 \% \text {, and } \\
\text { on human Acyl CoA: cholesterol transferase } 2 \\
\text { (hACAT2) by } 4.8 \pm 13.4 \%, 45.6 \pm 4.8 \% \text { and } \\
39.5 \pm 4.3 \% \text {, respectively. }\end{array}$ & 216 \\
\hline & ethanolic & The influence of ethanolic extracts of Brassica & 217 \\
\hline
\end{tabular}




\begin{tabular}{|c|c|c|c|}
\hline & extracts & $\begin{array}{l}\text { campestris spp. rapa roots (EBR) on obesity } \\
\text { was examined in imprinting control region } \\
\text { (ICR) mice fed a high-fat diet (HFD) and in } \\
\text { 3T3-L1 adipocytes. The molecular mechanism } \\
\text { of the anti-obesity effect of EBR was } \\
\text { investigated in 3T3-L1 adipocytes as well as } \\
\text { in HFD-fed ICR mice. In the obese mouse } \\
\text { model, both weight gain and epididymal fat } \\
\text { accumulation were highly suppressed by the } \\
\text { daily oral administration of 50 mg/kg EBR for } \\
8 \text { weeks, whereas the overall amount of food } \\
\text { intake was not affected. EBR treatment } \\
\text { induced the expression in white adipocytes of } \\
\text { lipolysis-related genes, including beta3- } \\
\text { adrenergic receptor (beta3-AR), hormone- } \\
\text { sensitive lipase (HSL), adipose triglyceride } \\
\text { lipase, and uncoupling protein } 2 . \text { Furthermore, } \\
\text { the activation of cyclic AMP-dependent } \\
\text { protein kinase, HSL, and extracellular signal- } \\
\text { regulated kinase was induced in EBR-treated } \\
\text { 3T3-L1 cells. The lipolytic effect of EBR } \\
\text { involved beta3-AR modulation, as inferred } \\
\text { from the inhibition by the beta3-AR } \\
\text { antagonist propranolol. Accordingly, EBR } \\
\text { may have potential as a safe and effective } \\
\text { anti-obesity agent via the inhibition of } \\
\text { adipocyte lipid accumulation and the } \\
\text { stimulation of beta3-AR-dependent lipolysis. }\end{array}$ & \\
\hline \multirow[t]{2}{*}{ Caesalpinia crista } & methanol extract & $\begin{array}{l}\text { The methanol extract significantly }(\mathrm{P}<0.05) \\
\text { decreased the levels of lipid peroxidation and } \\
\text { significantly }(\mathrm{P}<0.05) \text { increased the levels of } \\
\text { GSH, superoxide dismutase and catalase, } \\
\text { when administered at the doses of } 50,100 \text {, } \\
\text { and } 200 \mathrm{mg} / \mathrm{kg} \text { body weight per day for } 14 \\
\text { days in mice. }\end{array}$ & 218 \\
\hline & Aqueous extract & $\begin{array}{l}\text { Aqueous extract in isoproterenol treated rats } \\
\text { significantly decreased plasma total } \\
\text { cholesterol, TC }(87.45 \pm 1.5) \text {, triglycerides TG } \\
(91.59 \pm 2.12) \text {, LDL }(67.79 \pm 1.80) \text {, VLDL } \\
(12.46 \pm 0.68) \text {, along with a significant } \\
\text { increased in HDL level }(18.67 \pm 0.72) \text { when } \\
\text { compared to untreated isoproterenol group. } \\
\text { Ethanolic extract of Caesalpinia Crista }+ \\
\text { isoproterenol treated group showed decrease } \\
\text { lipoproteins level except HDL of plasma. } \\
\text { Caesalpinia crista aqueous extract treated } \\
\text { group showed significantly decrement plasma } \\
\text { TC (81.23 } \pm 1.99) \text {, TG (73.82 } \pm 1.34) \text { LDL } \\
\text { (60.34 } \pm 1.56) \text {, VLDL (10.53 } \pm 0.54) \text {, along with } \\
\text { a significant (P<0.01) increased in HDL level } \\
(19.38 \pm 1.25) \text { when compared to untreated } \\
\text { isoproterenol group. }\end{array}$ & 88 \\
\hline Calotropis procera & root extracts & $\begin{array}{l}\text { Serum lipid profile was measured in the } \\
\text { diabetic rats. The extracts were significantly } \\
(\mathrm{p}<0.001) \text { decreased total cholesterol, } \\
\text { triglycerides, phospholipids, LDL and VLDL } \\
\text { cholesterol and significantly ( }<<0.001) \\
\text { increased HDL cholesterol. }\end{array}$ & 219 \\
\hline Capparis spinosa & different extracts & Leaves and flowers of Capparis spinosa were & $220-$ \\
\hline
\end{tabular}




\begin{tabular}{|c|c|c|c|}
\hline & of different parts & $\begin{array}{l}\text { rich in either polyphenols or flavonoids, while } \\
\text { roots are the poor ones. All extracts have anti } \\
\text { lipid peroxidation and antioxidant effects with } \\
\text { a dominance of flowers and leaves especially } \\
\text { in the methanolic extracts }(82.78 \pm 2.64 \text { and } \\
80.94 \pm 1.57 \text { respectively). Seeds exerted the } \\
\text { acceptable effects followed by bud than roots. }\end{array}$ & 221 \\
\hline $\begin{array}{l}\text { Capsicum annuum and } \\
\text { Capsicum frutescens }\end{array}$ & aqueous extract & $\begin{array}{l}\text { The anti-obesity effects of water extracts of } \\
\text { seven Capsicum annuum L. varieties, } \\
\text { Putgochu (Pca), Oyee gochu (Oca), Kwari } \\
\text { putgochu (Kca), Green pepper (Gca), Yellow } \\
\text { paprika (Yca), Red paprika (Rca) and } \\
\text { Cheongyang gochu (Cca), were examined } \\
\text { through the evaluation of lipoprotein lipase } \\
\text { (LPL) mRNA expression level in 3T3-L1 cells } \\
\text { (mouse pre-adipocytes). After capsaicin } \\
\text { elimination by chloroform defatting, freeze- } \\
\text { dried powder of Cca was treated to 3T3-L1 } \\
\text { cells and anti-obesity effects were examined } \\
\text { by determining the LPL mRNA level using } \\
\text { the RT-PCR method. Of the primary fractions, } \\
\text { only proven fractions underwent secondary } \\
\text { and tertiary re-fractionating to determine anti- } \\
\text { obesity effects. From seven different } \\
\text { Capsicum annuum, there was a significant } \\
\text { decrease of the LPL mRNA expression level } \\
\text { of } 50.9 \% \text { in Cca treatment compared to the } \\
\text { control group. A significant decrease of the } \\
\text { LPL mRNA expression level was shown in } \\
\text { primary fractions (Fr) } 5 \text { (36.2\% decrease) and } \\
6 \text { (30.5\% decrease) of the Cca water extracts. } \\
\text { Due to the impurities checked by UPLC } \\
\text { chromatography, Fr } 5 \text { and } 6 \text { were re- } \\
\text { fractionated to determine the LPL mRNA } \\
\text { expression level. Treatment of Fr } 6-6 \text { ( } 35.8 \% \\
\text { decrease) and Fr 5-6 ( } 35.3 \% \text { decrease) showed } \\
\text { a significant decrease in the LPL mRNA } \\
\text { expression level. When analyzed using UPLC, } \\
\text { major compounds of Fr 6-6 and Fr 5-6 were } \\
\text { very similar. Subsequently, Fr 6-6 and Fr 5-6 } \\
\text { were re-fractionated to isolate the major peak } \\
\text { for structure elucidation. Treatment of Fr 5-6- } \\
1 \text { ( } 26.6 \% \text { decrease) and Fr 6-6-1 ( } 29.7 \% \\
\text { decrease) showed a significant decrease in the } \\
\text { LPL mRNA expression level. }\end{array}$ & $\begin{array}{l}222- \\
223\end{array}$ \\
\hline \multirow[t]{2}{*}{ Carum carvi } & aqueous extract & $\begin{array}{l}\text { The hypolipidemic effect of aqueous extract } \\
\text { of Carum carvi seeds ( } 60 \mathrm{mg} / \mathrm{kg} \text { of body } \\
\text { weight for eight weeks) was investigated in } \\
\text { diet induced hyperlipidemia in rats. Carum } \\
\text { carvi and simvastatin significantly decreased } \\
\text { lipids levels in rats. Carum carvi extract } \\
\text { reduced lipid levels more effectively than the } \\
\text { simvastatin. Carum carvi constituents, } \\
\text { especially flavonoids and carvone have strong } \\
\text { anti-oxidant activity which might be involved } \\
\text { in hypolipidemia. }\end{array}$ & $\begin{array}{l}224- \\
225\end{array}$ \\
\hline & $\begin{array}{l}\text { aqueous extract } \\
\text { of the seeds }\end{array}$ & $\begin{array}{l}\text { Oral administration of caraway to rats, } 1 \mathrm{~g} / \mathrm{kg} \\
\text { body weight, daily caused a significant } \\
\text { decrease in blood glucose level }(\mathrm{p}=0.001) \text { and }\end{array}$ & 226 \\
\hline
\end{tabular}




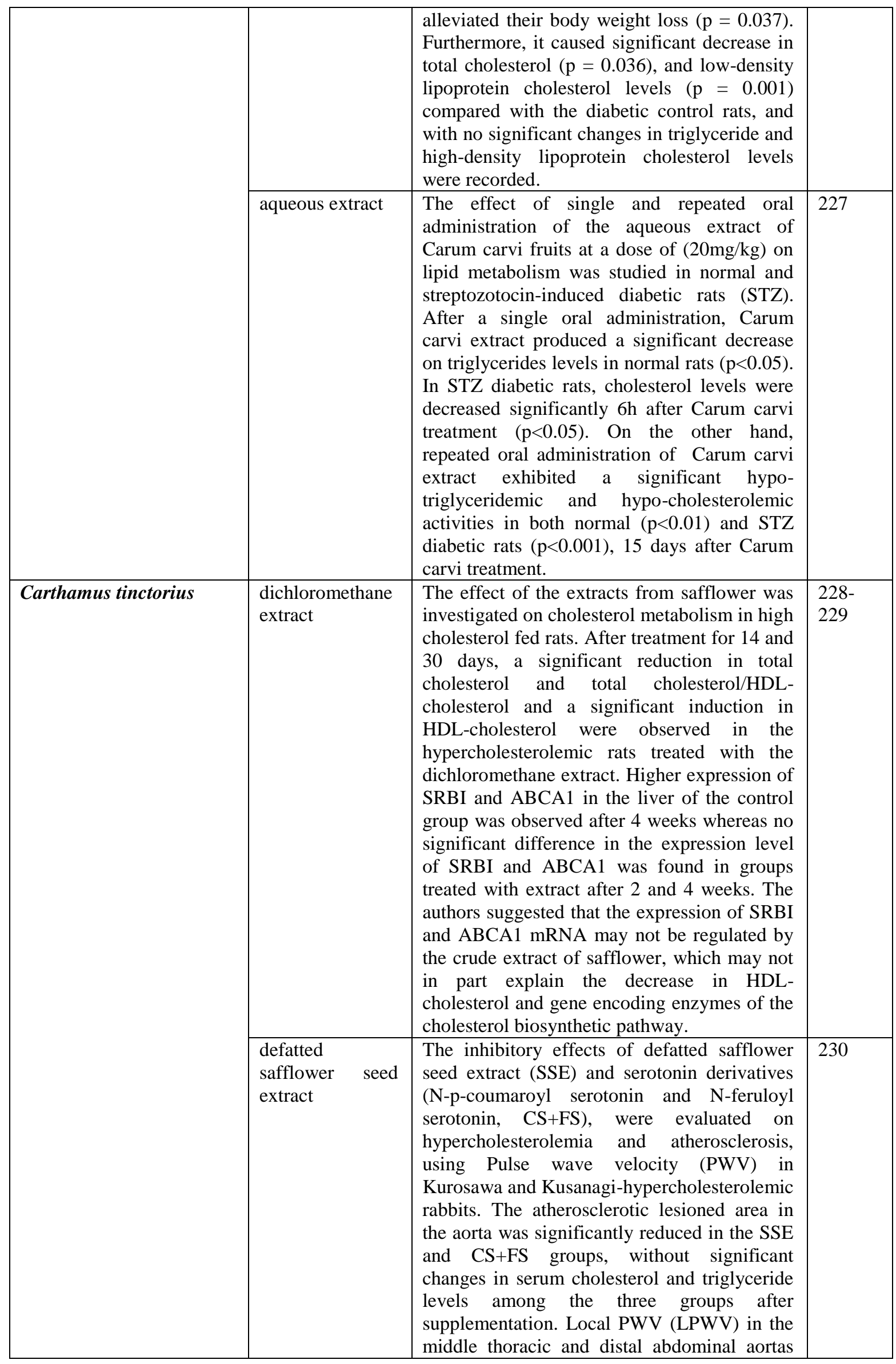




\begin{tabular}{|c|c|c|c|}
\hline & & $\begin{array}{l}\text { was significantly smaller in the SSE and } \\
\text { CS+FS groups than in the control group. } \\
\text { PWV in the entire aorta was also significantly } \\
\text { lower in the SSE and CS+FS groups, } \\
\text { compared with that in the control group. } \\
\text { Pressure-strain elastic modulus, an index of } \\
\text { wall distensibility, was significantly lower in } \\
\text { the middle thoracic and middle abdominal } \\
\text { aortas in the SSE and CS+FS groups than in } \\
\text { the control group. Wall thickness was also } \\
\text { significantly smaller in the middle thoracic } \\
\text { aorta in the SSE and CS+FS groups compared } \\
\text { with that in the control group. }\end{array}$ & \\
\hline \multirow[t]{2}{*}{ Casuarina equisetifolia } & $\begin{array}{l}\text { Casuarina } \\
\text { equisetifolia bark }\end{array}$ & 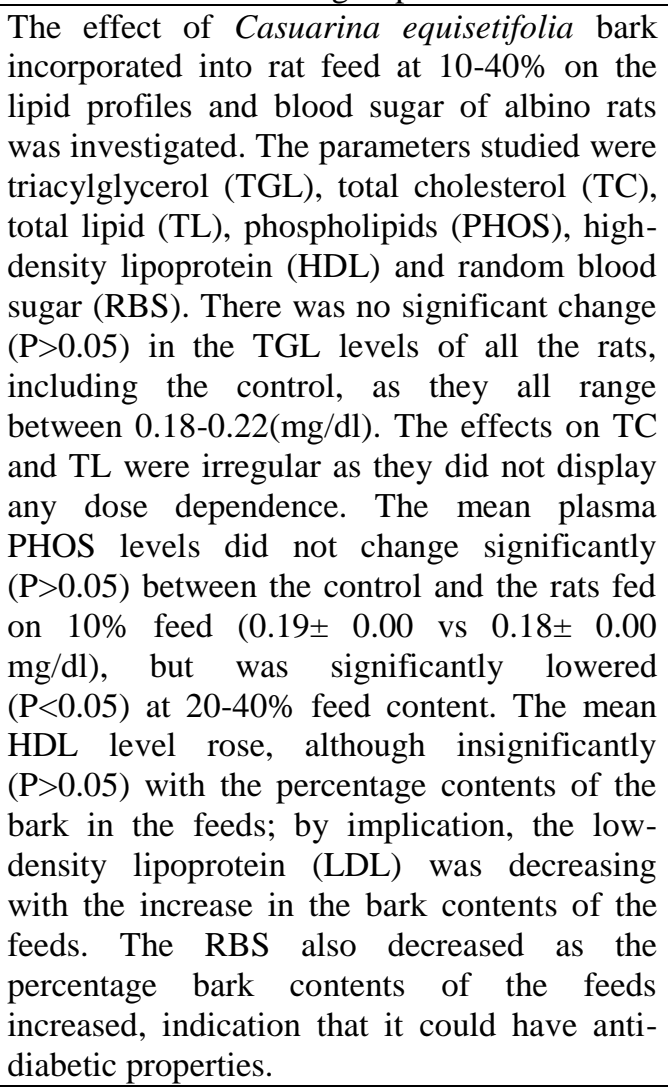 & $\begin{array}{l}231- \\
232\end{array}$ \\
\hline & bark extracts & $\begin{array}{l}\text { The effect of extracts of Casuarina } \\
\text { equisetifolia bark on serum lipid profile, total } \\
\text { cholesterol, triglycerides, low density, very } \\
\text { low density and high density lipoprotein was } \\
\text { evaluated in the diabetic and non diabetic rats. } \\
\text { There was significant reduction in total } \\
\text { cholesterol, LDL cholesterol, VLDL } \\
\text { cholesterol and improvement in HDL } \\
\text { cholesterol in diabetic rats. }\end{array}$ & 233 \\
\hline Cistanche tubulosa & $\begin{array}{l}\text { aqueous ethanol } \\
\text { extract (CTE) of } \\
\text { the roots }\end{array}$ & $\begin{array}{l}\text { The hypocholesterolemic effect of the } \\
\text { aqueous ethanol extract (CTE) of the roots of } \\
\text { Cistanche tubulosa was evaluated in mice } \\
\text { using gene chip and RT-PCR analysis of the } \\
\text { livers of mice given CTE ( } 400 \mathrm{mg} / \mathrm{kg} \text { ) for } 14 \\
\text { days. The administration of CTE }(400 \mathrm{mg} / \mathrm{kg} \text { ) } \\
\text { for } 14 \text { days significantly suppressed serum } \\
\text { cholesterol elevation in high cholesterol diet- } \\
\text { fed mice. The mRNA expressions of VLDL } \\
\text { receptor and cytochrome P450 SCC were }\end{array}$ & 234 \\
\hline
\end{tabular}




\begin{tabular}{|c|c|c|c|}
\hline & & $\begin{array}{l}\text { significantly enhanced. In addition, acteoside, } \\
\text { a major constituent of CTE, was found to } \\
\text { enhance the mRNA expressions of } \\
\text { apolipoprotein B, VLDL receptor, and } \\
\text { cytochrome P450 SCC in HepG2 hepatocytes. } \\
\text { According to these results, the authors } \\
\text { concluded that CTE affected the mRNA } \\
\text { expressions of molecules related to cholesterol } \\
\text { transport and metabolism and exhibited } \\
\text { hypocholesterolemic activity in diet-induced } \\
\text { hypercholesterolemia mice. Acteoside was } \\
\text { involved in the hypocholesterolemic activity } \\
\text { of CTE. }\end{array}$ & \\
\hline \multirow[t]{3}{*}{ Citrullus colocynthis } & powdered seeds & $\begin{array}{l}\text { The hypolipidemic effect of Citrullus } \\
\text { colocynthis was studied clinically. One } \\
\text { hundred dislipidemic patients were randomly } \\
\text { divided into two treated and placebo groups. } \\
\text { They were treated daily with powdered seeds } \\
\text { of Citrullus colocynthis ( } 300 \mathrm{mg} \text { ) and placebo } \\
\text { for } 6 \text { weeks. A daily intake of } 300 \mathrm{mg} / \text { day of } \\
\text { powdered seeds of Citrullus colocynthis can } \\
\text { lower the triglyceride and cholesterol } \\
\text { concentration significantly in nondiabetic } \\
\text { hyperlipidemic patients. }\end{array}$ & $\begin{array}{l}235- \\
236\end{array}$ \\
\hline & $\begin{array}{l}\text { Citrus } \\
\text { aurantifolia peel } \\
\text { essential oil }\end{array}$ & $\begin{array}{l}\text { The effect of Citrus aurantifolia peel essential } \\
\text { oil was studied on serum triglyceride and } \\
\text { cholesterols in Wistar rats. Thirty Wistar rats } \\
\text { were divided into } 5 \text { groups: control, sham, and } \\
3 \text { experimental groups. The animals were } \\
\text { treated in } 2 \text { phases: first, except for control } \\
\text { group, which received normal saline, the rest } \\
\text { of the groups were fed with a high cholesterol } \\
\text { regimen to induce hyperlipidemia; then, the } 3 \\
\text { experimental groups were treated with Citrus } \\
\text { aurantifolia peel essential oil in } 3 \text { different } \\
\text { doses: } 25,50 \text {, and } 100 \mu 1 / \mathrm{kg} \text {. The sham group } \\
\text { demonstrated a significant rise in mean serum } \\
\text { triglyceride, cholesterol, and LDL level in } \\
\text { comparison with the control group ( }<<0.05 \text { ). } \\
\text { The results of experimental groups treated } \\
\text { with peel essential oil in } 50 \text { and } 100 \mu 1 / \mathrm{kg} \\
\text { doses demonstrated a significant reduction in } \\
\text { triglyceride, cholesterol, and LDL (p<0.01). }\end{array}$ & 237 \\
\hline & $\begin{array}{l}\text { Citrus } \\
\text { aurantifolia juice }\end{array}$ & $\begin{array}{l}\text { The effect of Citrus aurantifolia on hepatic } \\
\text { lipidomics was studied in female albino rats, it } \\
\text { was found that the fresh juice of lime had } \\
\text { different effects on cholesterol, riacylglycerol } \\
\text { and phospholipid concentrations of the liver. } \\
\text { The low concentration of lime juice }(30 \mu l) \text { did } \\
\text { not showed considerable effect on cholesterol } \\
\text { concentration of the liver. Increase in } \\
\text { cholesterol concentration was observed only } \\
\text { after applying a concentration of } 60 \mu 1 \text {. } \\
\text { Beyond this concentration, cholesterol } \\
\text { concentration was decreased. Therefore, it } \\
\text { was demonstrated that peak stimulation for } \\
\text { lime juice is } 60 \mu 1 \text {. Similar effect also occur for } \\
\text { triacylglycerol concentration. However, it } \\
\text { caused dose-dependent increase in }\end{array}$ & 238 \\
\hline
\end{tabular}




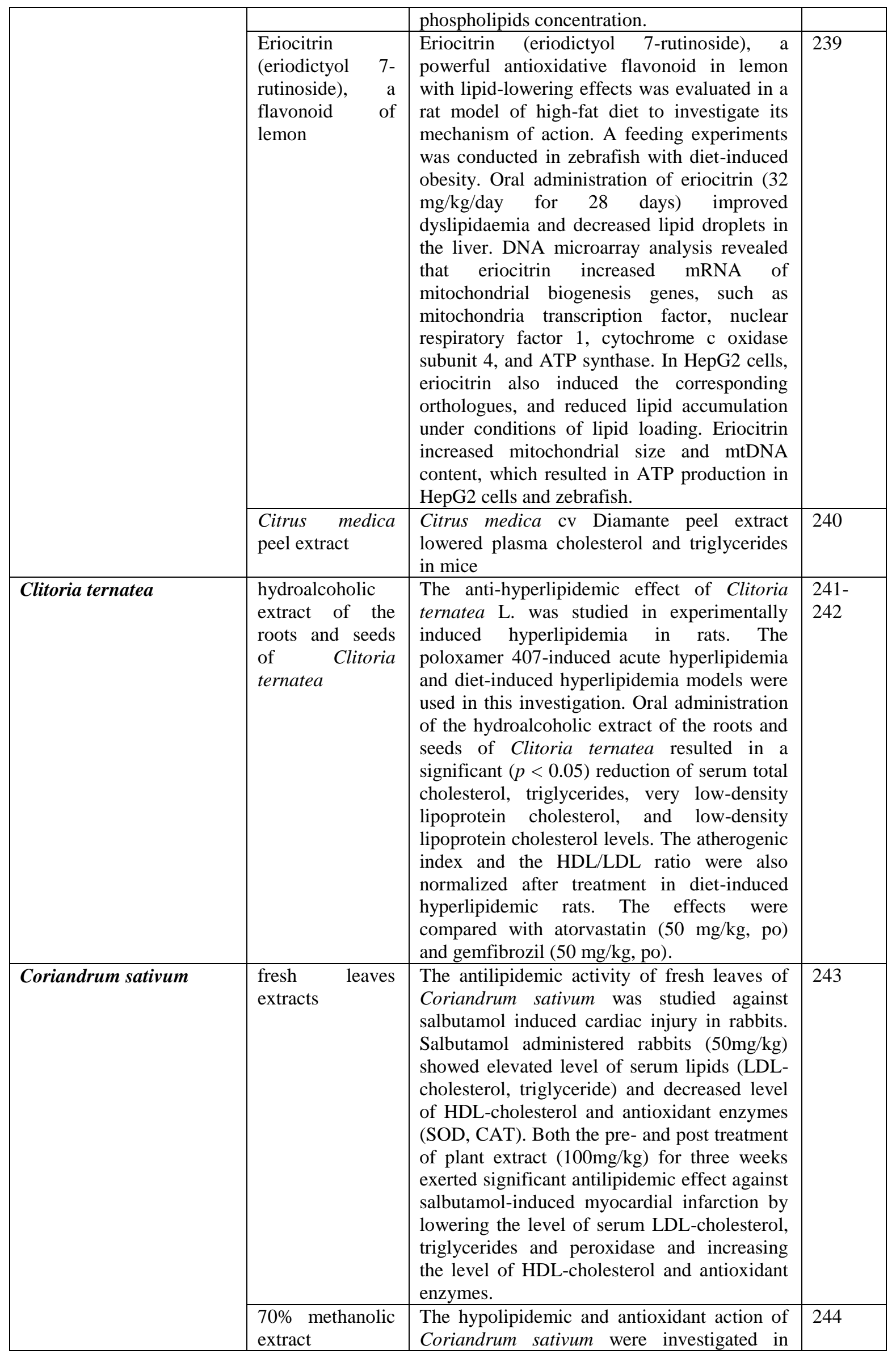




\begin{tabular}{|c|c|c|c|}
\hline & & $\begin{array}{l}\text { cholesterol-fed rabbits. Cholesterol feeding } \\
\text { (500 mg/ kg bw/day) for } 120 \text { days caused a } \\
\text { significant increase in serum total cholesterol, } \\
\text { phospholipid, triglyceride, LDL-cholesterol } \\
\text { and VLDL-cholesterol levels, whereas HDL } \\
\text { ratio was decreased significantly when } \\
\text { compared with control group. The changes in } \\
\text { the antioxidant parameters were accompanied } \\
\text { by an increase in hepatic lipid peroxidation } \\
\text { and reduction in glutathione (GSH) and } \\
\text { catalase activity. The level of lipid } \\
\text { peroxidation was reduced whereas GSH } \\
\text { content and catalase activity were elevated } \\
\text { after the treatment with } 70 \% \text { methanolic } \\
\text { extract of Coriandrum sativum at a dose of } \\
\text { 500 mg/kg bw/day. Reduced serum lipid } \\
\text { profile and elevated HDL ratio was observed } \\
\text { after administration of Coriandrum sativum. } \\
\text { Coriandrum sativum extract feeding increased } \\
\text { the faecal excretion of cholesterol and } \\
\text { phospholipids. Histological studies showed } \\
\text { less cholesterol deposits in the aorta of high } \\
\text { cholesterol diet animals given Coriandrum } \\
\text { sativum compared to the high cholesterol diet } \\
\text { untreated animals. }\end{array}$ & \\
\hline & seeds & $\begin{array}{l}\text { Coriandrum sativum seeds were incorporated } \\
\text { into diet, and the effect of the of coriander } \\
\text { seeds on the metabolism of lipids was studied } \\
\text { in rats fed with high fat diet and added } \\
\text { cholesterol. The seeds had a significant } \\
\text { hypolipidemic action. In the experimental } \\
\text { group of rats (tissue) the level of total } \\
\text { cholesterol and triglycerides increased } \\
\text { significantly. There was significant increase in } \\
\text { beta-hydroxy, beta-methyl glutaryl CoA } \\
\text { reductase and plasma lecithin cholesterol acyl } \\
\text { transferase activity were noted in the } \\
\text { experimental group. The level of low density } \\
\text { lipoprotein (LDL) and very low density } \\
\text { lipoprotein (VLDL) cholesterol were } \\
\text { decreased, while that of high density } \\
\text { lipoprotein (HDL) cholesterol was increased } \\
\text { compared to the control group. }\end{array}$ & $\begin{array}{l}245- \\
246\end{array}$ \\
\hline \multirow[t]{2}{*}{ Crocus sativus } & crocin & $\begin{array}{l}\text { Serum triglycerides, total-, LDL-, cholesterol, } \\
\text { fecal excretion of fat and cholesterol were } \\
\text { significantely inhibited by crocin }(100 \\
\mathrm{mg} / \mathrm{kg} / \text { day) compared to the control group. }\end{array}$ & 247 \\
\hline & Crocetin & $\begin{array}{l}\text { Crocetin, was administered to rabbits to } \\
\text { determine its effect on the development of } \\
\text { atherosclerosis. New Zealand white rabbits } \\
\text { were given three different diets for eight } \\
\text { weeks: a standard diet, a high lipid diet } \\
\text { (HLD), or a high lipid + crocetin diet. The } \\
\text { HLD group developed hypercholesterolemia } \\
\text { and atherosclerosis, while the crocetin- } \\
\text { supplemented group decreased the negative } \\
\text { health effects of a high lipid diet. However, } \\
\text { the results did not show a significant } \\
\text { difference in the plasma lipid levels (total, low }\end{array}$ & 248 \\
\hline
\end{tabular}




\begin{tabular}{|c|c|c|c|}
\hline & & $\begin{array}{l}\text { density lipoprotein (LDL), and high density } \\
\text { lipoprotein (HDL) cholesterol) between the } \\
\text { HLD and crocetin groups but showed } \\
\text { significant decrease in the aorta cholesterol } \\
\text { deposits, atheroma, foam cells, and } \\
\text { atherosclerotic lesions. The authors suggested } \\
\text { that nuclear factor kappa B (NF- } \mathrm{B} \text { ) activation } \\
\text { in the aorta was suppressed by crocetin which } \\
\text { in turn decreased the vascular cell adhesion } \\
\text { molecule-1 (VCAM-1) expression. }\end{array}$ & \\
\hline & crocetin & $\begin{array}{l}\text { Administration of a monthly intramuscular } \\
\text { injection of crocetin reduced serum } \\
\text { cholesterol concentrations by } 50 \% \text {, and the } \\
\text { severity of atherosclerosis by } 30 \% \text { in rabbits } \\
\text { fed an atherosclerosis-inducing diet. Crocin } \\
\text { exerted antiatherosclerotic effects through } \\
\text { decreasing the level of Ox-LDL that plays an } \\
\text { important role in the initiation and progression } \\
\text { of atherosclerosis. }\end{array}$ & $\begin{array}{l}249- \\
250\end{array}$ \\
\hline & $\begin{array}{l}\text { fifty milligrams } \\
\text { saffron in } 100 \mathrm{ml} \\
\text { of milk }\end{array}$ & $\begin{array}{l}\text { Fifty milligrams of saffron dissolved in } 100 \\
\text { ml of milk was administered twice a day to } \\
\text { human subjects, the significant decrease in } \\
\text { lipoprotein oxidation susceptibility in patients } \\
\text { with coronary artery disease (CAD) indicated } \\
\text { the potential of saffron as an antioxidant. }\end{array}$ & 251 \\
\hline & $\begin{array}{l}\text { extract of saffron } \\
\text { stigma }\end{array}$ & $\begin{array}{l}\text { Healthy, mildly overweight women }(\mathrm{N}=60) \\
\text { participated in a randomized, placebo- } \\
\text { controlled, double-blind study to evaluated the } \\
\text { efficacy of satiereal supplementation (Inoreal } \\
\text { Ltd, Plerin, France), a novel extract of saffron } \\
\text { stigma, on body weight changes over an } 8 \text { - } \\
\text { week period. They took twice capsule of } \\
\text { satiereal (176.5 mg extract per day or a } \\
\text { matching placebo. Caloric intake was left } \\
\text { unrestricted during the study. At baseline, } \\
\text { both groups were homogeneous for age, body } \\
\text { weight, and snacking frequency. Satiereal } \\
\text { caused a significantly greater body weight } \\
\text { reduction than placebo after } 8 \text { weeks (p<0.01). } \\
\text { The mean snacking frequency was } \\
\text { significantly decreased in the satiereal group } \\
\text { as compared with the placebo group (P }<.05) \text {. } \\
\text { Other anthropometric dimensions and vital } \\
\text { signs remained almost unchanged in both } \\
\text { groups. No subject withdrawal attributable to } \\
\text { a product effect was reported throughout the } \\
\text { trial, suggesting a good tolerability to } \\
\text { satiereal. }\end{array}$ & 252 \\
\hline Crotalaria juncea & ethanolic extract & $\begin{array}{l}\text { The antihypercholesterolemic effects of } 50 \\
\text { and } 100 \mathrm{mg} / \mathrm{kg} \text { bw per day of an ethanolic } \\
\text { extract of Crotalaria juncea Linn (whole } \\
\text { plant) were investigated in rats fed high-fat } \\
\text { diet by evaluating food consumption, weight } \\
\text { gain, fecal fat excretion, serum and liver } \\
\text { lipids, and biochemical profiles as well as by } \\
\text { histopathological studies. The results were } \\
\text { compared to animals fed with the standard } \\
\text { diet and animals fed with a high-fat diet and } \\
\text { atorvastatin }(10 \mathrm{mg} / \mathrm{kg} \text { bw). The animal group }\end{array}$ & $\begin{array}{l}253- \\
254\end{array}$ \\
\hline
\end{tabular}




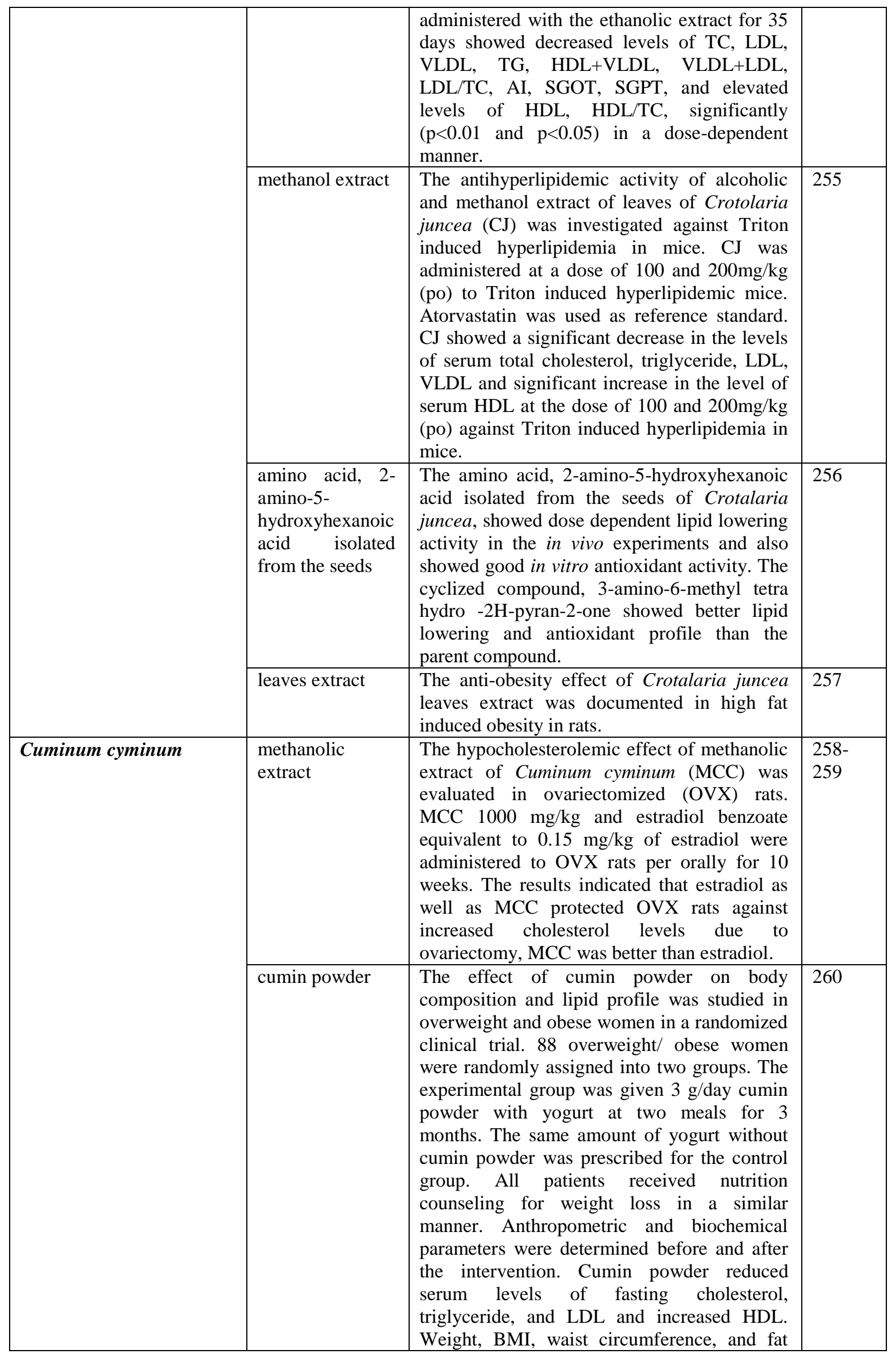




\begin{tabular}{|c|c|c|c|}
\hline & & $\begin{array}{l}\text { mass were also significantly reduced. } \\
\text { However, it exerted no effect on FBS and fat- } \\
\text { free mass. }\end{array}$ & \\
\hline & cumin extract & $\begin{array}{l}\text { The effects of cumin extract supplementation } \\
\text { on oxLDL, paraoxanase } 1 \text { activity, FBS, total } \\
\text { cholesterol, triglycerides, High density } \\
\text { lipoprotein cholesterol (HDL-C), low density } \\
\text { lipoprotein cholesterol (LDL-C), apo } \\
\text { lipoprotein A1 (Apo A1), and apolipoprotein } \\
\text { B (Apo B) were studied in the patients with } \\
\text { hypercholesterolemia. The results } \\
\text { demonstrated that there was a significant } \\
\text { decrease in the level of oxLDL after receiving } \\
\text { cumin. Paraoxonase and arylesterase activities } \\
\text { increased in serum after taking cumin extract. } \\
\text { Paraoxanase } 1 \text { (PON1) played a protective } \\
\text { role against the oxidative modification of } \\
\text { plasma lipoproteins and hydrolyzes lipid } \\
\text { peroxides in human atherosclerotic lesions. }\end{array}$ & 261 \\
\hline & Cumin capsule & $\begin{array}{l}\text { The effects of Cuminum cyminum intake on } \\
\text { weight loss and metabolic profiles among } \\
\text { overweight subjects was studied by a } \\
\text { randomized double-blind placebo-controlled } \\
\text { clinical trial which conducted among } 78 \\
\text { overweight subjects (male, } \mathrm{n}=18 \text {; female, } \mathrm{n}= \\
60) \text { aged } 18-60 \text { years old. Participants were } \\
\text { randomly assigned into three groups to } \\
\text { receive: (1) Cuminum cyminum capsule ( } \mathrm{n}= \\
26) ;(2) \text { orlistat } 120 \text { capsule ( }=26) \text { and }(3) \\
\text { placebo (n }=26) \text { three times a day for } 8 \\
\text { weeks. Anthropometric measures and fasting } \\
\text { blood samples were taken at baseline and after } \\
8 \text { weeks of intervention. Consumption of the } \\
\text { Cuminum cyminum and orlistat } 120 \text { resulted in } \\
\text { a similar significant decrease in weight }(-1.1 \pm \\
1.2 \text { and }-0.9 \pm 1.5 \text { compared with placebo } 0.2 \\
\pm 1.5 \mathrm{~kg}, \text { respectively, } \mathrm{p}=0.002) \text { and BMI }(- \\
0.4 \pm 0.5 \text { and }-0.4 \pm 0.6 \text { compared with } \\
\text { placebo } 0.1 \pm 0.6 \mathrm{~kg} / \mathrm{m}(2) \text {, respectively, } \mathrm{p}= \\
0.003) \text {. In addition, Cuminum cyminum L., } \\
\text { compared with orlistat and placebo, led to a } \\
\text { significant reduction in serum insulin levels }(- \\
1.4 \pm 4.5 \text { vs. } 1.3 \pm 3.3 \text { and } 0.3 \pm 2.2 \mu \mathrm{IU} / \mathrm{ml} \text {, } \\
\text { respectively, } \mathrm{p}=0.02), \mathrm{HOMA}-\mathrm{B}(-5.4 \pm 18.9 \\
\text { vs. } 5.8 \pm 13.3 \text { and } 1.0 \pm 11.0, \text { respectively, } \mathrm{p}= \\
0.02) \text { and a significant rise in QUICKI }(0.01 \pm \\
0.01 \text { vs. }-0.005 \pm 0.01 \text { and }-0.004 \pm 0.01 \text {, } \\
\text { respectively, } \mathrm{p}=0.02) \text {. }\end{array}$ & 262 \\
\hline Cupressus sempervirens & cone extract & $\begin{array}{l}\text { The effects of Cupressus sempervirens cone } \\
\text { extract (CSE) on the lipid profile was studied } \\
\text { in Wistar rats. The oral administration of the } \\
\text { extract resulted in a substantial decrease of } \\
\text { serum total cholesterol, which was significant } \\
\text { even after } 6 \text { weeks of treatment. Moreover, } \\
\text { these animals exhibited lower total cholesterol } \\
\text { levels compared to the controls after the } \\
\text { initiation of treatment ( }<0.001) \text {. The } \\
\text { administration of the extract also led to a } \\
\text { substantial reduction in serum triglycerides }\end{array}$ & $\begin{array}{l}263- \\
264\end{array}$ \\
\hline
\end{tabular}




\begin{tabular}{|c|c|c|c|}
\hline & & $\begin{array}{l}(\mathrm{p}<0.05) \text {, comparing } 0 \text { week to } 6-24 \text { weeks. } \\
\text { However no significant differences in } \\
\text { triglyceride levels were observed between } \\
\text { CSE animals and controls during the entire } \\
\text { study period. No significant changes in HDL- } \\
\text { cholesterol level. }\end{array}$ & \\
\hline \multirow[t]{2}{*}{ Cydonia oblonga } & leaf extracts & $\begin{array}{l}\text { The hypolipidemic effect of Cydonia oblonga } \\
\text { was studied in a rat model. low-, medium- and } \\
\text { high-dose Cydonia oblonga leaf extracts } \\
\text { (COM) were given orally for } 56 \text { days. The } \\
\text { normal controls were fed a normal diet, all } \\
\text { other groups a high fat diet. COM dose- } \\
\text { dependently reduced TC, TG, LDL-C and } \\
\text { MDA, inhibited the activity of ALT, AST and } \\
\text { LPS, increased HDL-C content, increased the } \\
\text { activity of SOD, GSH-PX, LPL and HL, and } \\
\text { reduced liver steatosis in hyperlipidaemia rats, } \\
\text { significant at medium and high doses. The } \\
\text { effect of COM was similar to that of } \\
\text { simvastatin except for increased lipoprotein } \\
\text { lipase and hepatic lipase which were reduced } \\
\text { by COM but not by simvastatin. }\end{array}$ & $\begin{array}{l}265- \\
266\end{array}$ \\
\hline & $\begin{array}{l}\text { total flavonoids } \\
\text { of } \quad \text { Cydonia } \\
\text { oblonga }\end{array}$ & $\begin{array}{l}\text { The effects of Cydonia oblonga Miller (COM) } \\
\text { total flavonoids (TF) from leaves and fruit on } \\
\text { the blood lipid and antioxidant potentials were } \\
\text { studied using hyperlipidaemic rat models. } \\
\text { Compared with the hyperlipidaemic model } \\
\text { group, TF significantly reduced serum TC, } \\
\text { TG, LDL-C ( }<0.01) \text {, ALT and AST ( }<0.01 \\
\text { or } \mathrm{p}<0.05 \text { ) and increased HDL-C ( }<0.05 \text { or } \\
\mathrm{p}<0.01) \text {. TF also reduced MDA (p<0.01 or } \\
\text { p<0.01). The effects of hydromethanolic } \\
\text { extract of quince leaf was investigated on the } \\
\text { lipid profile of rabbits fed with cholestrol } \\
\text { enriched diet ( } 2 \% \text { w/w for two months). } \\
\text { Animals were treated as follow: no treatment } \\
\text { (NT), atrovastatin (AT) (0.5 mg/kg/day) and } \\
\text { quince extract (QE) (dried extract, 50 } \\
\text { mg/kg/day) treatment, and then fed with } \\
\text { normal diet for three months. Significant } \\
\text { increases (p<0.05) in the mean values of } \\
\text { cholestrol I, triglyceride, low density } \\
\text { lipoprotein, aspartate aminotransferase, } \\
\text { alanine transaminase, creatinine, and alkaline } \\
\text { phosphatase with a significant decrease } \\
\text { (p<0.05) in high density lipoprotein level, } \\
\text { were recorded after receiving cholestrol } \\
\text { enriched diet in comparison with the control } \\
\text { group. }\end{array}$ & 267 \\
\hline Cyperus rotundus & $\begin{array}{l}\text { Rhizomes } \\
\text { extracts }\end{array}$ & $\begin{array}{l}\text { Hypolipidaemic activity of Cyperus rotundus } \\
\text { rhizomes was evaluated in high fat diet } \\
\text { induced hyperlipidaemic rats }(70,140 \text { and } 280 \\
\mathrm{mg} / \mathrm{kg} \text { bw). The results demonstrated } \\
\text { statically significant reduction in serum lipid } \\
\text { profile. Treatment with different doses of } \\
\text { extract exerted statistically significant } \\
(\mathrm{p}<0.05) \text { reduction in serum total cholesterol, } \\
\text { LDL, TG levels at the end of } 15 \text { days of } \\
\text { intervention. }\end{array}$ & 268 \\
\hline
\end{tabular}




\begin{tabular}{|c|c|c|c|}
\hline & tubers extract & $\begin{array}{l}\text { The biological efficacy of Cyperus rotundus } \\
\text { tubers extract was studied on weight control in } \\
\text { obese Zucker rats. Administration of } 45 \text { or } \\
220 \mathrm{mg} / \mathrm{kg} / \mathrm{day} \text { of Cyperus rotundus tubers } \\
\text { hexane extract for } 60 \text { days in Zucker rats } \\
\text { induced a significant reduction in weight gain } \\
\text { without affecting food consumption or } \\
\text { inducing toxicity. In vitro, } 250 \text { microg/ml of } \\
\text { this extract was able to stimulate lipolysis in } \\
\text { 3T3-F442 adipocytes suggesting that this } \\
\text { medicinal plant contained activators of beta- } \\
\text { adrenoreceptors (AR). The binding assay } \\
\text { performed on the rat beta3-AR isoform, } \\
\text { known to induce thermogenesis, demonstrated } \\
\text { that Cyperus rotundus tubers extract can } \\
\text { consistently and effectively bind to this } \\
\text { receptor. The data suggest that the effect on } \\
\text { weight gain exerted by Cyperus rotundus } \\
\text { tubers extract may be mediated, at least } \\
\text { partially, through the activation of the beta3- } \\
\text { AR. }\end{array}$ & 269 \\
\hline \multirow[t]{2}{*}{ Daucus carota } & $\begin{array}{l}\text { purple carrot } \\
\text { juice }\end{array}$ & $\begin{array}{l}\text { High-carbohydrate, high-fat diet-fed rats } \\
\text { developed hypertension, cardiac fibrosis, } \\
\text { increased cardiac stiffness, endothelial } \\
\text { dysfunction, impaired glucose tolerance, } \\
\text { increased abdominal fat deposition, altered } \\
\text { plasma lipid profile, liver fibrosis and } \\
\text { increased plasma liver enzymes together with } \\
\text { increased plasma markers of oxidative stress } \\
\text { and inflammation as well as increased } \\
\text { inflammatory cell infiltration. Purple carrot } \\
\text { juice reversed all these parameters. }\end{array}$ & 270 \\
\hline & $\begin{array}{l}\text { diet with carrot } \\
\text { (15\% dry matter) }\end{array}$ & $\begin{array}{l}\text { The effects of a } 3 \text {-week supplementation of } \\
\text { the diet with carrot ( } 15 \% \text { dry matter) in lipid } \\
\text { metabolism was studied in rats. A significant } \\
\text { decrease of cholesterol level in liver ( }-44 \% \text {; } \\
\mathrm{p}=0.0007 \text { ) was observed together with a } \\
\text { reduction of the level of liver triglycerides (- } \\
40 \% \text {; } \mathrm{P}=0.0005) \text {. Fecal total steroids } \\
\text { excretion increased by } 30 \% \text { upon feeding the } \\
\text { carrot diet as compared to the control. The } \\
\text { secretion of bile acids was maintained, } \\
\text { whereas the cholesterol apparent absorption } \\
\text { was reduced in rats fed carrot diet. }\end{array}$ & 271 \\
\hline Dolichos lablab & $\begin{array}{l}\text { supplementation } \\
\text { of the diet with } \\
\text { dried powder of } \\
\text { soaked bean }\end{array}$ & $\begin{array}{l}\text { The hypocholesterolemic effect of germinated } \\
\text { Indian bean (Dolichos lablab L. var lignosus) } \\
\text { was studied in hypercholesterolemic rats. } \\
\text { Supplementation of the diet with dried powder } \\
\text { of soaked bean almost brought the plasma } \\
\text { cholesterol to } 72.5 \pm 0.75 \text { from } 178 \pm 1.85 \\
\text { compared with that of the control } \\
(61.5 \pm 0.70) \text {, although the liver cholesterol } \\
\text { was still three times higher compared with the } \\
\text { control. The } 24 \mathrm{~h} \text { germinated Indian bean } \\
\text { cotyledons could effectively counteract the } \\
\text { effects of added cholesterol on liver and } \\
\text { plasma by their high fiber content coupled } \\
\text { with enormous increase in ascorbic acid } \\
\text { levels. }\end{array}$ & $\begin{array}{l}272- \\
273\end{array}$ \\
\hline
\end{tabular}




\begin{tabular}{|c|c|c|c|}
\hline \multirow[t]{2}{*}{ Echinochloa crusgalli } & $\begin{array}{l}\text { hydroalcoholic } \\
\text { extracts of } \\
\text { grains }\end{array}$ & $\begin{array}{l}\text { The anti-obesity effect of hydroalcoholic } \\
\text { extracts of Echinochloa crusgalli grains was } \\
\text { evaluated in high fat diet induced obesity in } \\
\text { albino rats. Obesity was induced by } \\
\text { administration of high fat diet for } 4 \text { weeks, the } \\
\text { obtained obese rats were treated with } \\
\text { hydroalcoholic extracts of Echinochloa } \\
\text { crusgalli grains in a dose of } 200,400 \text { and } 600 \\
\text { mg/kg, bw orally for next } 4 \text { weeks. } \\
\text { Echinochloa crusgalli caused significant } \\
\text { decrease in body weights, adipose tissue } \\
\text { weight, SGOT and SGPT levels, blood } \\
\text { glucose levels, LDL-C, VLDL-C, total } \\
\text { cholesterol, triglyceride levels, atherogenic } \\
\text { index, with a significant increase in HDL-C } \\
\text { levels compared with high fat diet control. }\end{array}$ & $\begin{array}{l}274- \\
275\end{array}$ \\
\hline & $\begin{array}{l}\text { methanolic } \\
\text { extract }\end{array}$ & $\begin{array}{l}\text { The curative effect of Echinochloa crusgalli } \\
\text { extract as antihypercholesterolemic therapy } \\
\text { was evaluated by performing in vivo studies } \\
\text { and and identifying its effects by on food } \\
\text { consumption, weight gain, fecal fat excretion, } \\
\text { serum lipid \&biochemical profiles. The } \\
\text { animal group administered methanolic extract } \\
\text { of the plant has shown decreased levels of TC, } \\
\text { LDL, VLDL, TG, HDL+VLDL, VLDL+LDL, } \\
\text { LDL/TC, AI, SGOT, SGPT and elevated } \\
\text { levels of HDL, HDL/TC in a dose dependent } \\
\text { manner significantly (p<0.01 \& p<0.05). } \\
\text { Body weight and food intake in treated groups } \\
\text { were significantly lower than that in model } \\
\text { control. }\end{array}$ & 276 \\
\hline
\end{tabular}

Plants with hemostatic, fibrinolytic or anticoagulant effects

\begin{tabular}{|c|c|c|c|}
\hline Plant & The tested constituent & Activity & Ref \\
\hline Achillea santolina & Crude extract & $\begin{array}{l}\text { Achillea santolina crude extract induced dose- } \\
\text { dependently inhibition in in vitro ADP and } \\
\text { collagen-induced human platelet aggregation } \\
\text { (maximal inhibition was } 34.4-2.9 \% \text { and } 78.3 \pm \\
2.5 \% \text { respectively). This effect was mostly } \\
\text { exerted by diethylester extract. Chloroform and } \\
\text { ethyl acetate extracts had about half the effect, } \\
\text { and water extract was devoid of antiaggregant } \\
\text { effect. However, when Achillea Santolina } \\
\text { extracts given to rats for } 10 \text { days (10 } \\
\text { mg/kg/day), they produced insignificant decline } \\
\text { in the thrombus weight. }\end{array}$ & 277 \\
\hline Allium cepa & $\begin{array}{l}\text { raw onions and the } \\
\text { essential oil }\end{array}$ & $\begin{array}{l}\text { Both raw onions and the essential oil increased } \\
\text { fibrinolysis in rabbits and humans. An increase } \\
\text { in coagulation time was also observed in } \\
\text { rabbits. Allium cepa inhibited platelet } \\
\text { aggregation in vitro and in vivo. An aqueous } \\
\text { extract of Allium cepa inhibited diphosphate, } \\
\text { epinephrine, arachidonic acid, adenosine, and } \\
\text { collagen induced platelet aggregation in vitro. } \\
\text { Essential oil, a butanol and chloroform extract } \\
\text { inhibited platelet aggregation in rabbits. } \\
\text { Chloroform, ethanol, butanol extract and the }\end{array}$ & $\begin{array}{l}278- \\
284\end{array}$ \\
\hline
\end{tabular}




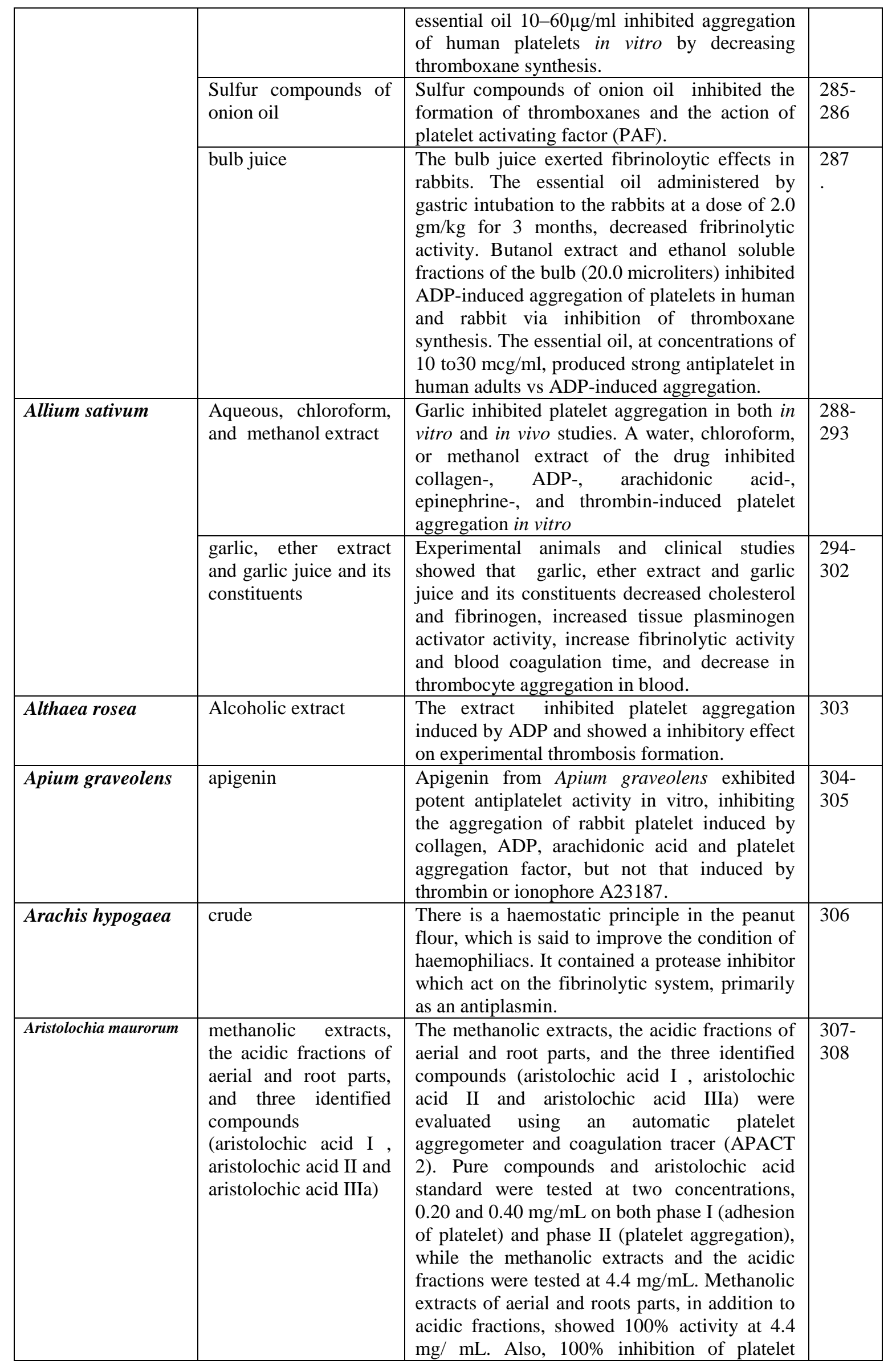




\begin{tabular}{|c|c|c|c|}
\hline & & $\begin{array}{l}\text { aggregation has been noted with aristolochic } \\
\text { acid standard and a mixture consisting of } 38 \% \\
\text { aristolochic acid I and } 58 \% \text { aristolochic acid II. } \\
\text { At } 0.40 \mathrm{mg} / \mathrm{mL} \text {, aristolochic acid I and II } \\
\text { exhibited } 100 \% \text { inhibition of platelet } \\
\text { aggregation. } 0.20 \mathrm{mg} / \mathrm{ml} \text { aristolochic acid I } \\
\text { selectively inhibited phase II with } 100 \% \\
\text { activity and phase I with } 39.5 \% \text { inhibition } \\
\text { while aristolochic acid II selectively inhibited } \\
\text { phase I (adhesion) with } 100 \% \text { inhibition, and } \\
\text { with less affinity towards phase II, inducing } \\
75.8 \% \text { inhibition. At } 0.20 \mathrm{mg} / \mathrm{ml} \text { aristolochic } \\
\text { acid IIIa exhibited } 100 \% \text { inhibition of the both } \\
\text { phases. At } 0.40 \mathrm{mg} / \mathrm{ml} \text { aristolochic acid IIIa } \\
\text { showed } 85.3 \% \text { and } 100 \% \text { inhibition of phase I } \\
\text { and phase II, respectively. Both aristolochic } \\
\text { acids, I and II, possessed good antithrombin } \\
\text { activity. }\end{array}$ & \\
\hline \multirow[t]{2}{*}{ Asclepias curassavica } & Cysteine proteases & $\begin{array}{l}\text { Cysteine proteases from Asclepias curassavica } \\
\text { latex exhibited strong pro-coagulant action. }\end{array}$ & $\begin{array}{l}309- \\
311\end{array}$ \\
\hline & $\begin{array}{l}\text { latex enzyme fraction } \\
\text { of } \\
\text { curassavica }\end{array}$ & $\begin{array}{l}\text { The latex enzyme fraction of Asclepias } \\
\text { curassavica exhibited strong proteolytic } \\
\text { activity when compared to trypsin and exerted } \\
\text { pro-coagulant action by reducing plasma } \\
\text { clotting time from } 195 \text { to } 58 \mathrm{~s} \text { whereas trypsin } \\
\text { reduced clotting time marginally from } 195 \text { to } \\
\text { 155s. The pro-coagulant activity of this enzyme } \\
\text { fraction was exerted by selectively hydrolyzing } \\
\text { A alpha and B beta subunits of fibrinogen to } \\
\text { form fibrin clot when pure fibrinogen was used } \\
\text { as substrate as assessed by fibrinogen-agarose } \\
\text { plate method and fibrinogen polymerization } \\
\text { assay. The electrophoretic pattern of latex } \\
\text { enzyme fraction-induced fibrin clot was very } \\
\text { much similar to that of thrombin-induced fibrin } \\
\text { clot and mimic thrombin like action. The } \\
\text { proteolytic activity including thrombin like } \\
\text { activity of Asclepias curassavica latex enzyme } \\
\text { fraction was completely inhibited by } \\
\text { iodoaceticacid. }\end{array}$ & $\begin{array}{l}310, \\
312\end{array}$ \\
\hline Brassica rapa & $\begin{array}{l}\text { crude extract and } \\
\text { fractions }\end{array}$ & $\begin{array}{l}\text { Crude extract and fractions of Brassica rapa } \\
\text { was screened against human platelet } \\
\text { aggregation induced by two different } \\
\text { aggregating agents and further delineated their } \\
\text { underlying signal transduction pathways. } \\
\text { Furthermore, Brassica rapa was screened for } \\
\text { the presence of calcium channel blocking } \\
\text { potential. The results showed that Brassica } \\
\text { rapa blocked calcium channel opening as } \\
\text { indicated by its effects on KCl-induced } \\
\text { contraction in guinea pig ileum and this activity } \\
\text { was distributed into various fraction of } \\
\text { Brassica rapa except ethyl acetate fraction } \\
\text { which did not show any significant calcium } \\
\text { channel blocking activity. Platelet aggregation } \\
\text { induced by arachidonic acid (AA), platelet } \\
\text { activating factor (PAF) and agonists of protein } \\
\text { kinase C (PKC) and inositol triphosphate (IP3) }\end{array}$ & 313 \\
\hline
\end{tabular}




\begin{tabular}{|c|c|c|c|}
\hline & & $\begin{array}{l}\text { was inhibited by various fractions of Brassica } \\
\text { rapa with different potencies, suggesting that } \\
\text { phyto compounds responsible for these effects } \\
\text { are differentially concentrated in various } \\
\text { fractions. }\end{array}$ & \\
\hline Calotropis procera & $\begin{array}{l}\text { proteins derived from } \\
\text { the latex }\end{array}$ & $\begin{array}{l}\text { The proteins derived from the latex (LP) of } \\
\text { Calotropis procera were evaluated for their } \\
\text { efficacy in maintaining coagulation } \\
\text { homeostasis in sepsis. Intraperitoneal injection } \\
\text { of LP markedly reduced the procoagulation and } \\
\text { thrombocytopenia observed in mice infected } \\
\text { with Salmonella; while in normal mice, LP } \\
\text { produced a procoagulant effect. In order to } \\
\text { understand its mechanism of action, the LP was } \\
\text { subjected to ion-exchange chromatography, and } \\
\text { the three subfractions (LPPI, LPPII, and } \\
\text { LPPIII) thus obtained were tested for their } \\
\text { proteolytic effect and thrombin- and plasmin- } \\
\text { like activities in vitro. Of the three subfractions } \\
\text { tested, LPPII and LPPIII exhibited proteolytic } \\
\text { effect on azocasein and exhibited procoagulant } \\
\text { effect on human plasma in a concentration- } \\
\text { dependent manner. Like trypsin and plasmin, } \\
\text { these subfractions produced both fibrinogeno - } \\
\text { lytic and fibrinolytic effects that were mediated } \\
\text { through the hydrolysis of the A } \alpha \text {, B } \beta \text {, and } \gamma \\
\text { chains of fibrinogen and } \alpha \text {-polymer and } \gamma- \\
\text { dimer of fibrin clot, respectively. }\end{array}$ & 314 \\
\hline Canna indica & fower extracts & $\begin{array}{l}\text { The hemostatic effect of Canna indica was } \\
\text { evaluated in mice. The bleeding time (BT), } \\
\text { clotting time (CT) and the permeability of } \\
\text { abdominal capillary were measured } \\
\text { respectively. The results showed that Canna } \\
\text { indica significantly reduce the BT, CT and the } \\
\text { permeability of abdominal capillary. }\end{array}$ & 315 \\
\hline Capparis spinosa & stachydrine & $\begin{array}{l}\text { When stachydrine was given to dogs, rabbits } \\
\text { and rats, it quickened the coagulation of blood. }\end{array}$ & 316 \\
\hline \multirow[t]{2}{*}{$\begin{array}{l}\text { Capsicum annuum and } \\
\text { Capsicum frutescens }\end{array}$} & ethanol extract & $\begin{array}{l}\text { An in-vitro thrombolytic model was used to } \\
\text { check the clot lysis effect of Capsicum } \\
\text { frutescens. A combination of honey and } \\
\text { Capsicum frutescens was also investigated } \\
\text { along with streptokinase as a positive control } \\
\text { and water as a negative control. By using an in } \\
\text { vitro thrombolytic model Capsicum frutescens } \\
\text { and a combination of honey and Capsicum } \\
\text { frutescens showed 57.40\% and } 44.54 \% \text { clot } \\
\text { lysis effect respectively. }\end{array}$ & 317 \\
\hline & capsaicin & $\begin{array}{l}\text { Capsaicin inhibited platelet aggregation and the } \\
\text { activity of clotting factors VIII and IX, a } \\
\text { property which reduce the incidence of } \\
\text { cardiovascular diseases. }\end{array}$ & $\begin{array}{l}318 \\
319\end{array}$ \\
\hline Carthamus tinctorius & carthamins yellow & $\begin{array}{l}\text { The effects of The carthamins yellow (CY) was } \\
\text { studied on a blood stasis model, which was } \\
\text { obtained by placing rats in ice-cold water } \\
\text { during the time interval between two injections } \\
\text { of epinephrine. The results demonstrated that } \\
\text { CY significantly decreased the whole blood } \\
\text { viscosity, plasma viscosity, and erythrocyte } \\
\text { aggregation index, which were increased in the }\end{array}$ & $\begin{array}{l}320 \\
321\end{array}$ \\
\hline
\end{tabular}




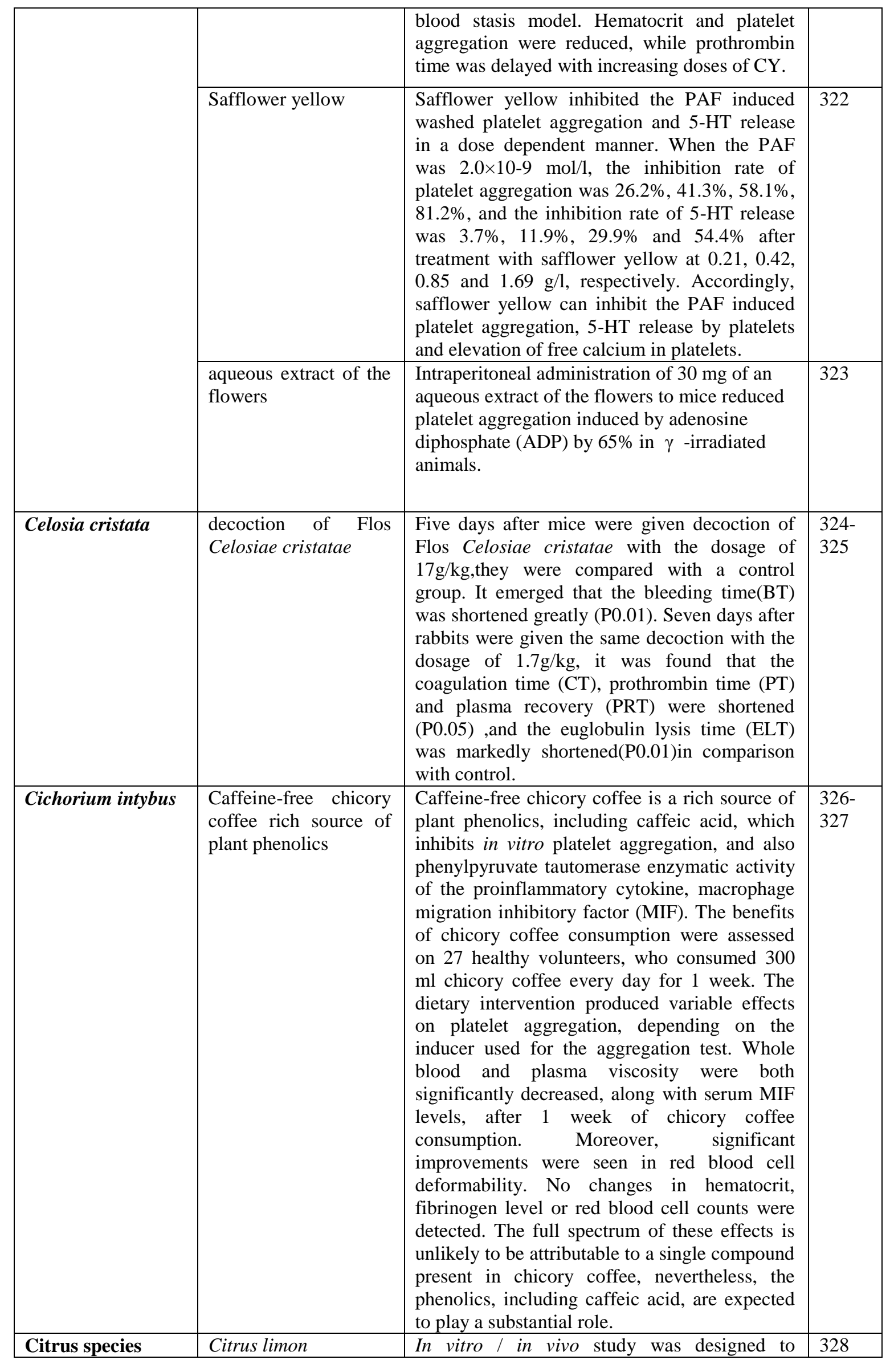




\begin{tabular}{|c|c|c|c|}
\hline & & $\begin{array}{l}\text { determine the effect of Citrus limon on blood } \\
\text { parameters, coagulation and anticoagulation } \\
\text { factors. In vitro tests revealed highly significant } \\
\text { increase in thrombin time and activated partial } \\
\text { thromboplastin time by Citrus limon, whereas } \\
\text { fibrinogen concentration was significantly } \\
\text { reduced in comparison to control, however } \\
\text { prothrombin time was not affected } \\
\text { significantly. In vivo testing of Citrus limon } \\
\text { was carried out at three different doses (0.2, } 0.4 \\
\text { and 0.6ml/kg) in healthy rabbits. Significant } \\
\text { changes were observed in hematological } \\
\text { parameters such as erythrocytes, hemoglobin } \\
\text { and mean corpuscular hemoglobin } \\
\text { concentration. Bleeding time and thrombin } \\
\text { time were significantly prolonged and there } \\
\text { was increase in protein C and thrombin } \\
\text { antithrombin complex levels. These results may } \\
\text { be due to inactivation of thrombin because it } \\
\text { significantly decreased fibrinogen } \\
\text { concentration and inhibited platelet } \\
\text { aggregation. Citrus limon showed maximal } \\
\text { anticoagulant effect at } 0.4 \mathrm{ml} / \mathrm{kg} \text {, which suggest } \\
\text { that Citrus limon possessed an anti-thrombin } \\
\text { component and could prevent thrombosis and } \\
\text { playing a cardio- protective role. }\end{array}$ & \\
\hline $\begin{array}{l}\text { Convolvulus } \\
\text { arvensis }\end{array}$ & $\begin{array}{l}\text { ethanolic and aqueous } \\
\text { extract }\end{array}$ & $\begin{array}{l}\text { Ethanolic and aqueous extract of Convolvulus } \\
\text { arvensis induced vasodilatation in rabbit } \\
\text { isolated aortic rings. The molecular level ( } \mathrm{K}^{+} \\
\text {and } \mathrm{Ca}^{+2} \text { channels and } \alpha 1 \text { receptors) of } \\
\text { vasodilator action of both ethanolic and } \\
\text { aqueous extract of Convolvulus arvensis was } \\
\text { studied in isolated and phenylephrine- } \\
\text { precontracted rabbit aortic rings. The role of } \\
\text { potassium channels was determine by using } \\
\text { two potassium channels blockers } \\
\text { [glibenclamide and tetraethyl ammonium } \\
\text { (TEA)], the aortic rings were contracted by } \\
\text { using high } \mathrm{K}^{+} \mathrm{Krebs} \text { solution in order to test the } \\
\text { role of voltage gated calcium channels } \\
\text { (VGCC). The concentration- response curves } \\
\text { of phenylephrine in rings were carried out } \\
\text { before and after added the two extracts in } \\
\text { different doses to examine the role of } \alpha 1 \\
\text { receptors. The results showed that calcium- } \\
\text { dependent K channels (BKCa) has a partial role } \\
\text { in the relaxing effect of the ethanolic extract, } \\
\text { while the } \mathrm{K}^{+} \text {channels did not exhibit role in } \\
\text { case of aqueous extract. With the using of high } \\
\mathrm{K}^{+} \text {Krebs, both extracts exhibited relaxant } \\
\text { effect due to reducing the entry of calcium ions } \\
\text { from outside. }\end{array}$ & $\begin{array}{l}329- \\
331\end{array}$ \\
\hline \multirow[t]{2}{*}{ Crocus sativus } & hot aqueous extract & $\begin{array}{l}\text { A hot aqueous extract of Crocus sativus } 10- \\
100 \mathrm{mg} / \mathrm{ml} \text {, prolonged partial thromboplastin } \\
\text { and prothrombin times, and inhibited platelet } \\
\text { aggregation in human platelets induced by } \\
\text { adenosine diphosphate and collagen in vitro. }\end{array}$ & $\begin{array}{l}332- \\
333\end{array}$ \\
\hline & aqueous extract & $\begin{array}{l}\text { The inhibitory activity of saffron extract was } \\
\text { studied on human platelets. Platelet aggregation }\end{array}$ & 334 \\
\hline
\end{tabular}




\begin{tabular}{|c|c|c|c|}
\hline & & $\begin{array}{l}\text { and lipid peroxidation were evaluated with } \\
\text { platelet rich plasma (PRP) and platelet } \\
\text { membranes obtained from blood of healthy } \\
\text { human volunteers. Human platelets were } \\
\text { subjected to stimulation with a variety of } \\
\text { agonists like ADP ( } 61 \text { microM), epinephrine } \\
\text { ( } 76 \text { microM), collagen ( } 11 \text { microg/ml), calcium } \\
\text { ionophore A } 23187 \text { (6 microM) and ristocetin } \\
\text { ( } 1.25 \text { microg/ml) in the presence and absence } \\
\text { of saffron extract. The inhibitory effect was } \\
\text { dose dependent with concentrations varying } \\
\text { between } 0.16 \text { to } 0.80 \text { mg and time dependent. A } \\
\text { significant decrease was observed in } \\
\text { malondialdehyde (MDA) formed, one of the } \\
\text { end products of arachidonic acid metabolism } \\
\text { and of serotonin released from dense granules } \\
\text { of platelets at respective IC50. Lipid } \\
\text { peroxidation in platelet membranes induced by } \\
\text { iron-ascorbic acid system was inhibited by } \\
\text { saffron extract significantly with IC50 of } 0.33 \\
\text { mg. Hence, it may be said that aqueous extract } \\
\text { of saffron may have component(s), which } \\
\text { protect platelets from aggregation and lipid } \\
\text { peroxidation. }\end{array}$ & \\
\hline Cuminum cyminum & ethereal extract & $\begin{array}{l}\text { Extract of cumin inhibited arachidonate- } \\
\text { induced platelet aggregation. It also inhibited } \\
\text { thromboxane B2 production from exogenous } \\
\text { (14C) arachidonic acid (AA) in washed } \\
\text { platelets, in addition, a simultaneous increase in } \\
\text { the formation of lipoxygenase-derived products } \\
\text { was also observed. }\end{array}$ & 335 \\
\hline Cydonia oblonga & $\begin{array}{ll}\text { Cydonia } & \text { oblonga } \\
\text { Miller (COM) extracts }\end{array}$ & $\begin{array}{l}\text { The effects of Cydonia oblonga Miller (COM) } \\
\text { extracts was investigated on models and } \\
\text { markers of thrombosis and related biomarkers } \\
\text { in mice. } 20,40,80 \mathrm{mg} / \mathrm{kg} / \mathrm{day} \mathrm{COM} \text { aqueous } \\
\text { extracts or } 5 \mathrm{mg} / \mathrm{kg} / \mathrm{day} \text { aspirin, were given } \\
\text { orally for } 14 \text { days and were compared to } \\
\text { untreated controls regarding bleeding and } \\
\text { clotting times, using the tail cutting and glass } \\
\text { slide methods and for death rates in collagen- } \\
\text { epinephrine pulmonary thrombosis, } \\
\text { thrombolysis in vitro and euglobulin lysis time } \\
\text { (ELT). Common carotid artery FeCl } 3 \text {-induced } \\
\text { thrombus and inferior vena cava thrombosis } \\
\text { occlusion time, plasma concentrations of } \\
\text { thromboxane B2 (TXB }) \text { and } 6-\mathrm{keto}- \\
\text { prostaglandine F1 } \alpha \text { (6-keto-PGF } 1 \alpha) \text { were } \\
\text { measured. Compared to controls, COM extracts } \\
\text { dose-dependently prolonged bleeding by } 2.17 \text {, } \\
2.78 \text { and } 3.63 \text { times, compared with aspirin } \\
2.58 \text {, and the clotting time by } 1.44,2.47 \text { and } \\
2.48 \text { times, compared with aspirin } 1.91 . \text { COM } \\
\text { reduced pulmonary embolus mortality by } 27 \text {, } \\
40 \text { and } 53 \% \text {, compared with } 47 \% \text { for aspirin. } \\
\text { COM dose-dependently increased thrombolysis } \\
\text { by } 45 \text {, 55 and } 63 \% \text {, compared with } 56 \% \text { for } \\
\text { aspirin, and shortened ELT to } 71,61 \text { and } 43 \% \text {, } \\
\text { compared with } 43 \% \text { for aspirin. In rats, venous } \\
\text { occlusion time was prolonged. Arterial and }\end{array}$ & 336 \\
\hline
\end{tabular}




\begin{tabular}{|c|c|c|c|}
\hline & & $\begin{array}{l}\text { venous thrombus weights were dose- } \\
\text { dependently reduced in COM groups. TXB2 } \\
\text { decreased and 6-keto-PGF1 } \alpha \text { increased with } \\
\text { COM and aspirin, with an association between } \\
\text { 6-keto-PGF1 } \alpha / \mathrm{TXB} 2 \text { and arterial or venous } \\
\text { thrombus weight for all products, and for } \\
\text { occlusion time with COM but not for aspirin. }\end{array}$ & \\
\hline Cynodon dactylon & leaves juice extract & $\begin{array}{l}\text { The haemostatic activity of Cynodon dactylon } \\
\text { was studied in albino rats. The Bleeding Time } \\
\text { (BT) in control group was } 160.5 \pm 8.3 \text { second } \\
\text { and in test group } 96.8 \pm 10.3 \text { second. The } \\
\text { Clotting Time (CT) in control group was } 507.6 \\
\pm 18.2 \text { second and in test group } 319.3 \pm 27.1 \\
\text { second. }\end{array}$ & $\begin{array}{l}337- \\
338\end{array}$ \\
\hline Cyperus rotundus & Ethanolic extract & $\begin{array}{l}\text { The antiplatelet activities of Cyperus rotundus } \\
\text { ethanolic extract (CRE) and eight of its } \\
\text { constituent compounds were evaluated by } \\
\text { examining their effects on rat platelet } \\
\text { aggregations in vitro and ex vivo, and on mice } \\
\text { tail bleeding times. During the in vitro platelet } \\
\text { aggregation study, CRE showed significant and } \\
\text { concentration dependent inhibitory effects on } \\
\text { collagen-, thrombin-, and/or arachidonic acid } \\
\text { (AA)-induced platelet aggregation. Of its eight } \\
\text { components, (+)-nootkatone was found to have } \\
\text { the most potent inhibitory effect on collagen-, } \\
\text { thrombin-, and AA-induced platelet } \\
\text { aggregation. In addition, CRE- and (+)- } \\
\text { nootkatone-treated mice exhibited significantly } \\
\text { prolonged bleeding times. Furthermore, (+)- } \\
\text { nootkatone had a significant inhibitory effect } \\
\text { on rat platelet aggregation ex vivo. In studying } \\
\text { the effect of Cyperus rotundus on the } \\
\text { hemorrheological changes in normal rats, } \\
\text { Cyperus rotundus can improve all } \\
\text { hemorrheological indexes, such as the whole } \\
\text { blood specific viscosity, the plasma specific } \\
\text { viscosity, erythrocyte electrophoresis, etc. }\end{array}$ & $\begin{array}{l}339- \\
341\end{array}$ \\
\hline Equisetum arvense & aqueous extracts & $\begin{array}{l}\text { The extract of Equisetum arvense produced a } \\
\text { dose-dependent inhibition of thrombin and } \\
\text { ADP-induced platelet aggregation. The effect } \\
\text { of the plant could be related in part to the } \\
\text { polyphenolic compounds present in the extract } \\
\text { suggesting their involvement in the treatment } \\
\text { or prevention of platelet aggregation } \\
\text { complications linked to cardiovascular } \\
\text { diseases. }\end{array}$ & $\begin{array}{l}342- \\
343\end{array}$ \\
\hline Erigeron canadensis & $\begin{array}{lll}\text { different parts of } \\
\text { extract }\end{array}$ & $\begin{array}{l}\text { The effects of different parts of extract of the } \\
\text { plant on platelet aggregation in vitro were } \\
\text { investigated. Aqueous extract young or old } \\
\text { plants, glycoconjugate part, polysaccharide part } \\
\text { and aglycon part at the concentrations above } \\
0.75 \mathrm{mg} / \mathrm{ml} \text { strongly inhibited platelet } \\
\text { aggregation induced by collagen }(2 \text { microg/ml) } \\
\text { in dose-dependent manner. Polysaccharide part } \\
\text { isolated from plant extract had the strongest } \\
\text { inhibitory effect on aggregation stimulated by } \\
\text { collagen and seems to be responsible for } \\
\text { antiaggregatory properties. }\end{array}$ & $\begin{array}{l}344- \\
345\end{array}$ \\
\hline
\end{tabular}




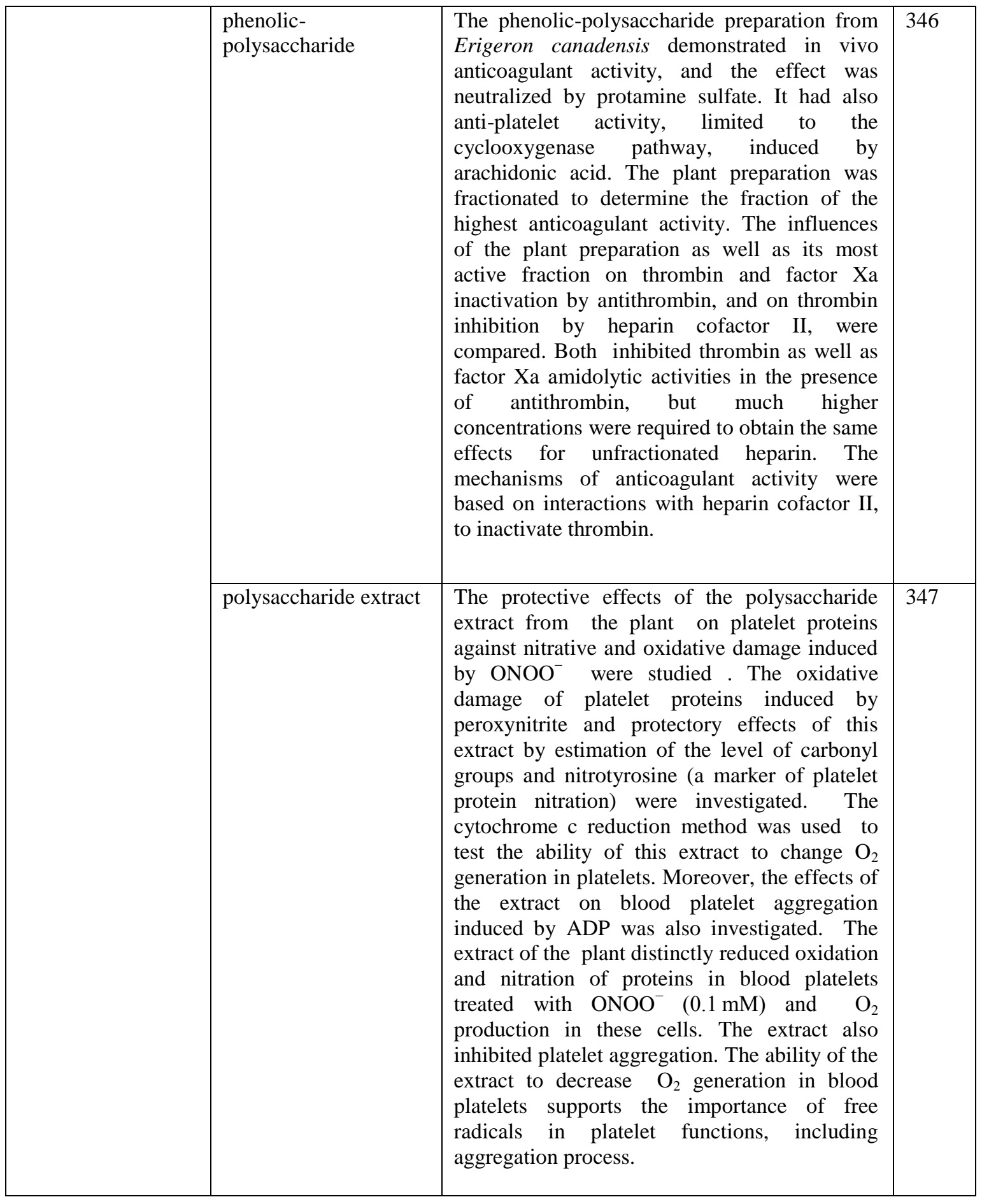

\section{CONCLUSION:}

With the high prevalence of herbal medicine use worldwide. the information regarding the therapeutic use or safety of herbal remedies usually obtained from books and pamphlets, most of which base their information on traditional reputation rather than relying on existing scientific research. This review highlights the cardiovascular effects of the medicinal plants as proved experimentally or clinically by the previous works.

\section{REFERENCES:}

[1] Al-Snafi AE. Therapeutic properties of medicinal plants: a review of plants with cardiovascular effects (part 1). Int J of Pharmacology \& Toxicology 2015; 5(3): 163-176.

[2] Al-Snafi AE. Medicinal plants with cardiovascular effects (part 2): plant based review. IOSR Journal of Pharmacy 2016; 6(7): 43-62. 
[3] Al-Snafi AE. Therapeutic properties of medicinal plants: a review of plants with hypolipidemic, hemostatic, fibrinolytic and anticoagulant effects (part 1). Asian Journal of Pharmaceutical Science \& Technology 2015; 5(4): 271-284.

[4] Shinde S, Shastry S and Agrawal S L.Cardiovascular effects of aqueous extract of Adonis vernalis. IX Annual conference of IPS , 76-77. http://lib.hebust.edu.cn/ywyfzsk/zsk/pharm-docum/b014.pdf

[5] Petkov V. Plants with hypotensive, antiatheromatous and coronarodilatating action. Am J Chin Med 1979; 7: 197-236.

[6] Al-Snafi AE. The pharmacological and therapeutic importance of Agrimonia eupatoria- A review. Asian Journal of Pharmaceutical Science and Technology 2015; 5(2): 112-117.

[7] Al-Qattan KK, Alnaqeeb MA, Ali M et al.The antihypertensive effect of garlic (Allium sativum) in the rat two-kidney-one-clip Goldblatt model. Journal of Ethnopharmacology 1999; 66: 217-222.

[8] Ali M, Al-Qattan KK, Al-Enezi F et al. Effect of allicin from garlic powder on serum lipids and blood pressure in rats fed with a high cholesterol diet. Prostaglandins Leukotrienes and Essential Fatty Acids 2001; 62(4): 253-259.

[9] Fallon MB, Abrams GA, Abdel-Razek TT et al. Garlic prevents hypoxic pulmonary hypertension in rats. Am J Physiol Lung Cell Mol Physiol 1988; 275: L283-L287.

[10] Silagy CA and Neil HA. A meta-analysis of the effect of garlic on blood pressure. J Hypertens 1994; 12 : 463-468.

[11] Aqel MB, Gharaibah MN and Salhab AS. Direct relaxant effects of garlic juice on smooth and cardiac muscles. J Ethnopharmacol 1991; 33: 13-19.

[12] Al-Snafi AE. Pharmacological effects of Allium species grown in Iraq. An overview. International Journal of Pharmaceutical and health care Research 2013;1(4):132-147.

[13] Al-Snafi AE. The pharmaceutical importance of Althaea officinalis and Althaea rosea : A Review. Int J Pharm Tech Res 2013; 5(3): 1387-1385.

[14] Durate J, Perez-Vizcaino F, Torres AI, Zarzuelo A, Jimenez J and Tamargo J. Vasodilator effects of visnagin in isolated rat vascular smooth muscle. Eur J Pharmacol 1995; 286(2): 115-122.

[15] Durate J, Vallejo I, Perez - Vizcaino F, Jimenez R, Zarzuelo A and Tamargo J. Effects of visnadine on rat isolated vascular smooth muscles. Planta Med 1997; 63(3): 233-236.

[16] Durate J, Torres A I and Zarzuelo A. Cardiovacular effects of visnagin on rats. Planta Med 2000; 66(1): 35- 39.

[17] Rauwald HW, Brehm H and Odenthal KP. Screening of nine vasoactive medicinal plants for their possible calcium antagonist activity. Strategy of selection and isolation for the active principles of Olea europaea and Peucedanaum ostruthium. Phytotherapy Research 1994; 8: 135-140.

[18] Rauwald HW, Brehm H and Odenthal KP. The involvement of $\mathrm{Ca}^{2+}$ channel blocking mode of action in the pharmacology of Ammi visnaga fruits. Planta Medica 1994; 60: 101-105.

[19] Erbring H, Uebel $\mathrm{H}$ and Vogel G. Zur Chemie, Pharmakologie und Toxicologie von Visnadin. Arzneimittelforschung 1967; 17: 283-287.

[20] Al-Snafi AE. Chemical constituents and pharmacological activities of Ammi majus and Ammi visnaga. A review. International Journal of Pharmacy and Industrial Research 2013; 3(3):257-265.

[21] Duarte J, Pérez-Vizcaíno F, Torres AI, Zarzuelo A, Jiménez J and Tamargo J. Vasodilator effects of visnagin in isolated rat vascular smooth muscle. Eur J Pharmacol 1995; 286(2):115-122.

[22] Altinterim B. Hiltan tohumunun (Umbelliferae, Ammi visnaga L.) düz kaslar üzerine etkisi. Nevşehir Dergisi Üniversitesi Fen Bilimleri Enstitü 2012:60-64.

[23] Leung A Y, Foster S. Encyclopedia of common natural ingredients used in food, drugs and cosmetics. New York, John Wiley and Sons 1996.

[24] Yazdanparast R, Bahramikia S. Evaluation of the effect of Anethum graveolens L. crude extracts on serum lipids and lipoproteins profiles in hypercholesterolaemic rats. DARU 2008; 16(2):88-94.

[25] African pharmacopoeia. Vol.1. Lagos, Organization of African Unity, Scientific Technical and Research Commission 1985.

[26] Branković, S., Kitić, D., Radenković, M., Veljković, S., Kostić, M., Miladinović, B., \& Pavlović, D. Hypotensive and cardioinhibotory effects of the aqueous and ethanol extracts of celery (Apium graveolens, Apiaceae). Acta Medica Medianae 2010; 49(1): 13-16.

[27] Quist EE. Peanut (Arachis hypogaea L.) as a source of antihypertensive and antimicrobial peptides. PhD thesis, Uga Univ 2005. 
[28] Sobotka W, Flis M, Antoszkiewicz Z, Lipiński K and Zduńczyk Z. Effect of oat by-product antioxidants and vitamin $\mathrm{E}$ on the oxidative stability of pork from pigs fed diets supplemented with linseed oil. Arch AnimNutr 2012; 66(1): 27-38.

[29] Andersson KE, Axling U, Xu J, Swärd K, Ahrné S, Molin G, Holm C and Hellstrand P. Diverse effects of oats on cholesterol metabolism in C57BL/6 mice correlate with expression of hepatic bile acidproducing enzymes. Eur J Nutr 2013; 52(7): 1755-1769.

[30] Othman RA, Moghadasian MH and Jones PJ. Cholesterol-lowering effects of oat $\beta$-glucan. Nutr Rev 2011; 69(6): 299-309.

[31] Maki KC, Galant R, Samuel P, Tesser J, Witchger MS, Ribaya-Mercado JD, Blumberg JB and Geohas J. Effects of consuming foods containing oat beta-glucan on blood pressure, carbohydrate metabolism and biomarkers of oxidative stress in men and women with elevated blood pressure. Eur J ClinNutr 2007; 61(6): 786-795.

[32] Nie L, Wise ML, Peterson DM and Meydani M. Avenanthramide, a polyphenol from oats, inhibits vascular smooth muscle cell proliferation and enhances nitric oxide production. Atherosclerosis 2006; 186(2): 260-266.

[33] Al-Snafi AE. The Chemical constituents and pharmacological effects of Bryophyllum calycinum-A review. Journal of Pharma Sciences and Research 2013; 4(12): 171-176.

[34] John AO. Ojewole. Antihypertensive properties of Bryophyllum pinnatum \{(Lam) Oken $\}$ leaf extracts. Am J Hypertens 2002; 15: 34A-34A

[35] Prasad AK, Kumar S, Iyer SV, Sudani RJ and Vaidya SK. Pharmacognostical, phytochemical and pharmacological review on Bryophyllum pinnata. International Journal of Pharmaceutical \& Biological Archives 2012; 3(3):423-433.

[36] Datté YJ, Traoré A, Offoumou AM. Anti-hypertensive effect of aqueous extract of Caesalpinia bonduc)Caesalpiniaceae) on arterial blood pressure in guinea-pig. Revue Med Pharm Afr 1997; 11: 79 88 .

[37] Al-Snafi AE. Pharmacology and medicinal properties of Caesalpinia crista - An overview. International Journal of Pharmacy 2015; 5(2): 71-83.

[38] Zeggwagh NA, Michel JB and Eddouks M. Cardiovascular effect of Capparis spinosa aqueous extract. Part VI: In vitro vasorelaxant effect. American Journal of Pharmacology and Toxicology 2007; 2(3): 135-139.

[39] Benzidane N, Imane K, Abderrahmane B, Noureddine C, Seddik K, Xavier N, and Lekhmici A. In vitro vasomotor effects of Capparis spinosa aqueous extracts. The 3rd International Symposium on the Medicinal Plants, Their Cultuvation and Aspects of Uses , BeitZaman Hotel \& Resort, Petra - Jordan, November 21-23/ 2012.

[40] Liu F, Wei Y, Yang XZ, Li FG, Hu J and Cheng RF. Hypotensive effects of safflower yellow in spontaneously hypertensive rats and influence on plasma renin activity and angiotensin II level. Yao Xue Xue Bao 1992; 27(10): 785-787

[41] Bai Y, Lu P, Han C, Yu C, Chen M, He F and Yi D, Wu L. Hydroxysafflor yellow A (HSYA) from flowers of Carthamus tinctorius L. and its vasodilatation effects on pulmonary artery. Molecules 2012; 17(12): 14918-14927.

[42] Nie PH, Zhang L, Zhang WH, Rong WF and Zhi JM. The effects of hydroxysafflor yellow A on blood pressure and cardiac function. J Ethnopharmacol 2012; 139(3): 746-750.

[43] Takimoto T, Suzuki K, Arisaka H, Murata T, Ozaki H and Koyama N. Effect of N-(pcoumaroyl)serotonin and $\mathrm{N}$-feruloylserotonin, major anti-atherogenic polyphenols in safflower seed, on vasodilation, proliferation and migration of vascular smooth muscle cells. Mol Nutr Food Res 2011; 55(10): 1561-1571.

[44] Zeggwagh NA, Michel JB and Eddouks M. Vascular effects of aqueous extract of Chamaemelum nobile: in vitro pharmacological studies in rats. Clin Exp Hypertens 2013; 35(3): 200-206.

[45] Pedroche J, Vioque J, Millan F, Alaiz M, Gir J and Yust MM. Production of ACE inhibitory peptides by digestion of chickpea legumin with alcalase. Food Chemistry 2003; 81: 363-369.

[46] Al-Snafi AE. The medical Importance of Cicer arietinum - A review. IOSR Journal of Pharmacy 2016; 6(3): 29-40.

[47] Sakurai N, Iizuka T, Nakayama S, Funayama H, Noguchi M and Nagai M. Vasorelaxant activity of caffeic acid derivatives from Cichorium intybus and Equisetum arvense. Yakugaku Zasshi 2003; 123(7):593-598. 
[48] Yoshikawa M, Matsuda H, Morikawa T, Xie H, Nakamura S and Muraoka O. Phenylethanoid oligoglycosides and acylated oligosugars with vasorelaxant activity from Cistanche tubulosa. Bioorg Med Chem 2006; 14(22):7468-7475.

[49] Ohnishi A, Asayama R, Mogi M, Nakaoka H, Kan-No H, Tsukuda K, Chisaka T, Wang XL, Bai HY, Shan BS, Kukida M, Iwanami J and Horiuchi M. Drinking citrus fruit juice inhibits vascular remodeling in cuff-induced vascular injury mouse model. PLoS One 2015; 10(2):e0117616.

[50] Akhtar SS. Evaluation of Cardiovascular Effects of Citrus aurantifolia (Linn.) Fruit. Social Science Research Network 2013, http://ssrn.com/abstract=2279447

[51] Souza A, Lamidi M, Ibrahim B, Samseny A, Mounanga MB and M'Batchi. B. Antihypertensive effect of an aqueous extract of Citrus aurantifolia (Rutaceae) (Christm.) Swingle, on the arterial blood pressure of mammal. International Research of Pharmacy and Pharmacology 2011; 1(7): 142-148.

[52] Perez YY, Jimenez-Ferrer E, Alonso D, Botello-Amaro CA and Zamilpa A. Citrus limetta leaves extract antagonizes the hypertensive effect of angiotensin II. Journal of Ethnopharmacology 2010; 128(3): 610614.

[53] Asgary S and Keshvari M. Effects of Citrus sinensis juice on blood pressure. ARYA Atheroscler 2013; 9(1): 98-101.

[54] Kumamoto H, Matsubara Y, Izuka Y, Okamoto K, Yokoi K. Structure and hypotensive effect of flavonoid glycosides in orange (Citrus sinensis OSBECK) peelings. Agric Biol Chemistry 1986; 50: 781783.

[55] Abuo-Shaaban RR, Angari AA, El-Tahir KE, Al-KhamisKI and Mirghani OM. Comparative hypotensive and respiratory stimulation effects of ripe and unripe fruit mucilage of Cordia myxa and Cordia obliqua in guineapigs and rabbits. Phytotherapy Res 1989; 3(4): 126-131.

[56] Al-Snafi AE. The Pharmacological and therapeutic importance of Cordia myxa- A review. IOSR Journal of Pharmacy 2016; 6(6): 47-57.

[57] Jabeen Q, Bashir S, Lyoussi B and Gilani AH. Coriander fruit exhibits gut modulatory, blood pressure lowering and diuretic activities. J Ethnopharmacol 2009;122(1):123-130.

[58] Al-Snafi AE. A review on chemical constituents and pharmacological activities of Coriandrum sativum. IOSR Journal of Pharmacy 2016; 6(7): 17-42.

[59] Medhin DG, Bakos P and Hadházy P. Inhibitory effects of extracts of Lupinus termis and Coriandrum sativum on electrically induced contraction of the rabbit ear artery. Acta Pharm Hung 1986; 56(3): 109. 113.

[60] Medhin DG, Hadhazy P, Bakos P and VerzarPetri G.Hypotensive effects of Lupinus termis and Coriandrum sativum in anesthetized rats: preliminary study. Acta Pharmaceutica Hungarica 1986; 56(2): 59-63.

[61] Liu N, Yang Y, Mo S, Liao J and Jin J.Calcium antagonistic effects of Chinese crude drugs: Preliminary investigation and evaluation by 45Ca. Applied Radiation and Isotopes 2005; 63:151-155.

[62] Imenshahidi M, Hosseinzadeh $\mathrm{H}$ and Javadpour $\mathrm{Y}$. Hypotensive effect of aqueous saffron extract (Crocus sativus L.) and its constituents, safranal and crocin, in normotensive and hypertensive rats. Phytother Res 2010; 24(7): 990-994.

[63] Imenshahidi M, Razavi BM, Faal A, Gholampoor A, Mousavi SM and Hosseinzadeh H. The effect of chronic administration of saffron (Crocus sativus) stigma aqueous extract on systolic blood pressure in rats. Jundishapur J Nat Pharm Prod 2013; 8(4): 175-179.

[64] Mancini A, Serrano-Díaz J, Nava E, D'Alessandro AM, Alonso GL, Carmona M and Llorens S. Crocetin, a carotenoid derived from saffron (Crocus sativus L.), improves acetylcholine-induced vascular relaxation in hypertension. J Vasc Res 2014; 51(5): 393-404.

[65] Kalaivani P, Saranya RB, Ramakrishnan G, Ranju V, Sathiya S, Gayathri V, Thiyagarajan LK, Venkhatesh JR, Babu CS and Thanikachalam S. Cuminum cyminum, a dietary spice, attenuates hypertension via endothelial nitric oxide synthase and NO pathway in renovascular hypertensive rats. Clin Exp Hypertens 2013; 35(7): 534-542.

[66] Zhou WT, Abdurahman A, Abdusalam E, Yiming W, Abliz P, Aji Q, Issak M, Iskandar G, Moore N and Umar A. Effect of Cydonia oblonga Mill. leaf extracts or captopril on blood pressure and related biomarkers in renal hypertensive rats. J Ethnopharmacol 2014; 153(3): 635-640.

[67] Zhou W, Abdusalam E, Abliz P, Reyim N, Tian S, Aji Q, Issak M, Iskandar G, Moore N and Umar A. Effect of Cydonia oblonga Mill fruit and leaf extracts on blood pressure and blood rheology in renal hypertensive rats. J Ethnopharmacol 2014; 152(3): 464-469.

[68] Gilani A, Shaheen F and Saeed SA. Cardiovascular action of Daucus carota. Archives of Pharmacal Research 1994; 17(3):150-153.

[69] Al-Snafi AE. Nutritional and therapeutic importance of Daucus carota- A review. IOSR Journal of Pharmacy 2017; 7(2): 72-88. 
[70] Gilani AH, Shaheeri F, Saeed SA, Bibi S, Irfanullah, Sadiq M and Faiz S. Hypotensive action of coumarin glycosides from Daucus carota. Phytomedicine 2000; 7(5):423-426.

[71] Joubert J P J. Cardiac glycosides. In: Toxicants of plant origin, Glycosides, ed. Cheeke PR, CRC Press, Boca Raton 1989: 61-96.

[72] Al-Snafi AE. Adonis aestivalis: pharmacological and toxicological activities- A revew. Asian Journal of Pharmaceutical Science \& Technology 2016; 6(2): 96-102.

[73] Philippine Medicinal Plants, Family, Asclepiadacea, Bulak-damo, Asclepias curassavica Linn. http://www.stuartxchange.com/Bulak-damo.html.

[74] Marashdah MS and AL-Hazimi HM. Pharmacological activity of ethanolic extract of Alhagi maurorum roots. Arabian Journal of Chemistry 2010; 3(1): 39-42.

[75] Al-Snafi AE. Alhagi maurorum as a potential medicinal herb: An Overview. International Journal of Pharmacy Review and Research 2015; 5(2):130-136.

[76] Al-Snafi AE. The pharmaceutical importance of Althaea officinalis and Althaea rosea : A Review. Int J Pharm Tech Res 2013; 5(3): 1387-1385.

[77] Quart SKJ. Hıltan tohumunun (Umbelliferae, Ammi visnaga L.) düz kaslar üzerine etkisi. Nevşehir Üniversitesi Fen Bilimleri Enstitü Dergisi 2012; 2: 60-64.

[78] Galal EE, Kandil A and Latif MA. Evaluation of cardiac inotropism of Ammi visnaga principles by the intra-ventricular technique. Journal of Drug Research of Egypt 1975; 7: 45-57.

[79] Anrep GV, Barsoum GS, Kenawy MR, and Misrahy G.Ammi visnaga in the treatment of angina syndrome. Gazette of the Faculty of Medicine Cairo 1975; 13: 39.

[80] Mahipal SK, Garg BD and Ahmad A. Hypotensive Action of Flowers of Anchusa strigosa (Gaozeban) . IX Annual Conferencev of IPS, 79. http://lib.hebust.edu.cn/ywyfzsk/zsk/pharm-docum/b014.pdf

[81] Al-Snafi AE. The pharmacology of Anchusa italica and Anchusa strigosa- A review. International Journal of Pharmacy and Pharmaceutical Sciences 2014; 6(4): 7-10.

[82] Mahran GH et al. Investigation of diuretic drug plants. 1-Phytochemical screening and pharmacological evaluation of Anethum graveolens L., Apium graveolens L., Daucus carota L. and Eruca sativa Mill. Phytotherapy Research1991; 5: 169-172.

[83] Al-Snafi AE. Chemical constituents and pharmacological effects of Asclepias curassavica - A review. Asian Journal of Pharmaceutical Research 2015; 5(2): 83-87.

[84] Rashid S, Lodhi F, Ahmad M and Usmanghani K. Cardiovascular effects of Bacopa monnieri (L.) pennel extract in rabbits. Pak J Pharm Sci 1990; 3(2): 57-62.

[85] Al-Snafi AE. The pharmacology of Bacopa monniera. A review. International Journal of Pharma Sciences and Research 2013; 4(12): 154-159.

[86] Felter HW. Monographs extracted from: The eclectic materia medica, pharmacology and therapeutics 1922. Michael Moore Bisbee (ed), Southwest School of Botanical Medicine, Arizona, 2001, 412-415.

[87] Al-Snafi AE. The pharmacological importance of Brassica nigra and Brassica rapa grown in Iraq. J of Pharm Biology 2015; 5(4): 240-253.

[88] Kumar SR and Kumar SA. Cardio protective effect of Caesalpinia crista Linn. on isoproterenol induced myocardial necrosis in rats. International Journal of Research in Pharmacy and Science 2013; 3(1): 119130.

[89] Ray D , Mukherjee S, Falchi M, Bertelli A and Das DK. Amelioration of myocardial ischemic reperfusion injury with Calendula officinalis. Curr Pharm Biotechnol 2010; 11(8): 849-854.

[90] Al-Snafi AE. The chemical constituents and pharmacological effects of Calendula officinalis - A review. Indian Journal of Pharmaceutical Science \& Research 2015; 5(3): 172-185.

[91] Mueen Ahmed KK, Rana AC and Dixit VK. Effect of Calotropis procera latex on isoproterenol induced myocardial infarction in albino rats. Phytomedicine 2004; 11: 327-330.

[92] Al-Snafi AE. The constituents and pharmacological properties of Calotropis procera - An Overview. International Journal of Pharmacy Review \& Research 2015; 5(3): 259-275.

[93] Moustafa AM, Ahmed SH, Nabil ZI, Hussein AA and Omran MA. Extraction and phytochemical investigation of Calotropis procera: effect of plant extracts on the activity of diverse muscles. Pharm Biol 2010; 48(10): 1080-1090.

[94] Han SY, Li HX, Ma X, Zhang K, Ma ZZ and Tu PF. Protective effects of purified safflower extract on myocardial ischemia in vivo and in vitro. Phytomedicine 2009; 16(8): 694-702.

[95] Wan L, Chen J, Li L, Xiong W and Zhou L. Protective effects of Carthamus tinctorius injection on isoprenaline-induced myocardial injury in rats. Pharmaceutical Biology 2009; 49(11): 1204-1209. 
[96] Zhang SQ and Jiang LD. Effect of safflower injection on cardiac energy charge and anti-apoptosis gene bcl-2 in rats' heart. Zhongguo Zhong Xi Yi Jie He Za Zhi 2004; 24(5): 442-444.

[97] Hotta Y, Nagatsu A, Liu W, Muto T, Narumiya C, Lu X, Yajima M, Ishikawa N, Miyazeki K, Kawai N, Mizukami H and Sakakibara J. Protective effects of antioxidative serotonin derivatives isolated from safflower against postischemic myocardial dysfunction. Mol Cell Biochem 2002; 238(1-2): 151-162.

[98] Tien YC, Lin JY, Lai CH, Kuo CH, Lin WY, Tsai CH, Tsai FJ, Cheng YC, Peng WH and Huang CY. Carthamus tinctorius L. prevents LPS-induced TNFalpha signaling activation and cell apoptosis through JNK1/2-NFkappaB pathway inhibition in H9c2 cardiomyoblast cells. J Ethnopharmacol 2010; 130(3): 505-513.

[99] Duan JL, Wang JW, Guan Y, Yin Y, Wei G, Cui J, Zhou D, Zhu YR, Quan W, Xi MM, Wen AD. Safflor yellow A protects neonatal rat cardiomyocytes against anoxia/reoxygenation injury in vitro. Acta Pharmacol Sin 2013; 34(4): 487-495.

[100] Wang CY, Zhang SP, Xu Y, Yang M, Jiang WG and Luan HY. Effect of safflor yellow B on vascular endothelial cells injury induced by angiotensin-II. Yao Xue Xue Bao 2012; 47(6): 811-815.

[101] Lei Z H, Kuniyasu A, Tai BS, Nakayama H and Nohara T. Na+,K+-ATPase inhibiting activity of cardiac glycosides from Erysimum cheiranthoides. Planta Med 2001; 67(4): 369-370.

[102] Al-Yahya MA, Mothana RA, Al-Said MS, El-Tahir KE, Al-103-Sohaibani M and Rafatullah S. Citrus medica "Otroj": Attenuates oxidative stress and cardiac dysrhythmia in isoproterenol-induced cardiomyopathy in rats. Nutrients 2013; 5: 4269-4283.

[103] Al-Snafi AE. Encyclopedia of the constituents and pharmacological effects of Iraqi medicinal plants. Thi qar University 2013.

[104] Al-Snafi AE. Nutritional value and pharmacological importance of citrus species grown in Iraq. IOSR Journal of Pharmacy 2016; 6(8): 76-108.

[105] Al-Snafi AE. The contents and pharmacological importance of Corchorus capsularis- A review. IOSR Journal of Pharmacy 2016; 6(6): 58-63.

[106] Patel RP and Patel M. Cardiotonic activity of isolated cardiac glycoside from fruit of Linn. Int Res J Pharm 2013; 3(7): 239-242.

[107] Dhanalakshmi R and Manavalan R. In silico docking approach for antiathero-seclerosis of and admet prediction. Asian J Pharm Clin Res 2015; 8(2): 350-353.

[108] Al-Snafi AE. The constituents and pharmacology of Corchorus aestuans: A review. The Pharmaceutical and Chemical Journal 2016; 3(4):208-214

[109] Al-Snafi AE. The contents and pharmacological importance of Corchorus capsularis- A review. IOSR Journal of Pharmacy 2016; 6(6): 58-63.

[110] Karrer P and Banergee P. Corchortoxinm a cardiac agent from jute seeds. Helv Chim Acta 1949; 32:2385-2392.

[111] Negm S, EI-Shabrawy O, Arbid M and Radwan AS. Toxicological study of the different organs of Corchorus olitorius L. plant with special reference to their cardiac glycosides content. Zeitsc Ernaehrungsw 1980; 19(1): 28-32.

[112] Rao EV, Rao DV, Pavanaram SK, von Euw J and Reichstein T. Structure of Corchoroside $\beta$ - Glycosides and aglycones. Helv Chim Acta 1971; 54(7): 1960-1968.

[113] Rao MR Liu TP and Meng ZJ. Comparative studies on the cardiotonic action of corchoroside A, ouabain and strophanthin K on the heart-lung preparation of guinea pig and cat. Yao Xue Xue Bao 1979; 14(5): 257-266.

[114] Patel DK, Desai SN, Gandhi HP, Devkar RV and Ramachandran AV. Cardio protective effect of Coriandrum sativum L. on isoproterenol induced myocardial necrosis in rats. Food Chem Toxicol 2012; 50(9):3120-3125.

[115] United States Dispensatory- 1918: 183-184. The Southwest School of Botanical Medicine http://www.swsbm.com

[116] Al-Snafi AE. The pharmacological and toxicological effects of Coronilla varia and Coronilla scorpioides: A Review. The Pharmaceutical and Chemical Journal 2016; 3(2):105-114.

[117] Slavík J, Zácková P, Michlová J, Opletal L and Sovová M. Phytotherapeutic aspects of diseases of the circulatory system. III. Cardiotonic and cardiotoxic effects of hyrcanoside and deglucohyrcanoside isolated from Coronilla varia L. Ceska Slov Farm 1994; 43(6):298-302.

[118] Zácková P, Sovová M, Horáková M and Opletalová V. Study of Coronilla varia L. III. Pharmacological evaluation of its effects on heart function. Cesk Farm 1982; 31(6):242-246.

[119] Gersl V. Effects of Coronilla varia Linné extract and lanatoside C in rabbits with experimental acute heart overloading in vivo. Sb Ved Pr Lek Fak Karlovy Univerzity Hradci Kralove 1980; 23(4): 445-457. 
[120] Biletskyi I. Cardiac glycosides from Coroilla varia. Farm Zh 1964; 19: 22-25.

[121] Chahine N, Hanna J, Makhlouf H, Duca L, Martiny L and Chahine R. Protective effect of saffron extract against doxorubicin cardiotoxicity in isolated rabbit heart. Pharm Biol 2013; 51(12):1564-1571.

[122] Mehdizadeh R, Parizadeh MR, Khooei AR, Mehri S and Hosseinzadeh H. Cardioprotective effect of saffron extract and safranal in isoproterenol-induced myocardial infarction in wistar rats. Iran $\mathbf{J}$ Basic Med Sci 2013; 16(1): 56-63.

[123] Sachdeva J, Tanwar V, Golechha M, Siddiqui KM, Nag TC, Ray R, Kumari S and Arya DS. Crocus sativus L. (saffron) attenuates isoproterenol-induced myocardial injury via preserving cardiac functions and strengthening antioxidant defense system. Exp Toxicol Pathol 2012; 64(6): 557-564.

[124] Boskabady MH, Shafei MN, Shakiba A and Sefidi HS. Effect of aqueous-ethanol extract from Crocus sativus (saffron) on guinea-pig isolated heart. Phytother Res 2008; 22(3): 330-334.

[125] Garjani A, Afrooziyan A, Nazemiyeh H, Najafi M, Kharazmkia A and Maleki-Dizaji N. Protective effects of hydroalcoholic extract from rhizomes of Cynodon dactylon (L) Pers on compensated right heart failure in rats. BMC Complement Altern Med 2009; 9: 28-36.

[126] Shabi MM, Raj David C, Sasikala C, Gayathri K and Joseph J. Negative inotropic and chronotropic effects of phenolic fraction from Cynodon dactylon (Linn) on isolated perfused frog heart. Journal of Scientific Research 2012; 4(3): 657-663.

[127] Nagulendran KR, Mahesh R and Begum VH, Preventive role of Cyperus rotundus rhizomes extract on age associated changes in glucose and lipids, Pharmacologyonline 2007; 2: 318-325.

[128] Kasa JK, Singh TU, Parida S, Addison MP, Darzi SA, Choudhury S, Kandasamy K, Singh V, Dash JR, Shanker K and Mishra SK. Assessment of Indian Rosewood (Dalbergia sissoo) Standardized Leaf Extract on Isoproterenol-InducedMyocardial Injury in Rats. Cardiovasc Toxicol 2015;15(3):250-260.

[129] Al-Snafi AE. Chemical constituents and pharmacological effects of Dalbergia sissoo - A review. IOSR Journal of Pharmacy 2017; 7(2): 59-71.

[130] Muralidharan P, Balamurugan G and Kumar P. Inotropic and Cardioprotective Effects of Daucus carota Linn. on isoproterenol-induced myocardial infarction. Bangladesh Journal of Pharmacology 2008; 3: 74 79.

[131] Whalen K, Finkel R and Panavelil TA. Lippincott illustrated reviews: pharmacology, $6^{\text {th }}$ Ed. Wolters Kluwer 2015: 263-265.

[132] Kaplan JH. Biochemistry of Na, K- ATPase. Annu Rev Biochem 2002; 71: 511-535.

[133] Smith TW. The fundamental mechanism of inotropic action of digitalis. Therapie 1989; 44: 431-435.

[134] Jorgensen PL, Hakansson KO and Karlish SJ. Structure and mechanism of Na, K-ATPase: functional sites and their interactions. Annu Rev Physiol 2003; 65: 817-849.

[135] Mason DT and Braunwald E. Studies on digitalis, X: effects of ouabain on forearm vascular resistance and venous tone in normal subjects and in patients in heart failure. J Clin Invest 1964; 43:532-543.

[136] Hauptman PJ and Kelly RA. Cardiovascular drugs, Digitalis. Circulation 1999; 99: 1265-1270.

[137] Al-Snafi AE. Phytochemical constituents and medicinal properties of Digitalis lanata and Digitalis purpurea - A review. Indo Am J P Sci 2017; 4(02): 225-234

[138] Al-Snafi AE. Pharmacology and therapeutics. Al Diaa Publication house 2013.

[139] Infra specific taxon details: Ephedra alata subsp alenda (Stapf) Trab., urn:lsid:catalogue oflife.org:taxon:9704b927-e478-11e5-86e7-bc764e092680:col20160426 [28 April 2016].

[140] Abula T, Rao SA, Mengistu A, Worku S, Legesse E and Aberra M. Pharmacology. University of Gondar 2004: 46.

[141] Al-Snafi AE. Therapeutic importance of Ephedra alata and Ephedra foliata- A review. Indo Am J P Sci 2017; 4(02): 399-406.

[142] Al-Snafi AE. Therapeutic potential of Erodium cicutarium - A review. Indo Am J P Sci 2017; 4(02): 407-413.

[143] Lis-Balchina MT and Hartb SL. A Pharmacological appraisal of the folk medicinal usage of Pelargonium grossularioides and Erodium cicutarium. Journal of Herbs, Spices \& Medicinal Plants1994; 2(3): 41-48.

[144] Lis-Balchina M and Guittonneaub GG. Preliminary investigations on the presence of alkaloids in the genus Erodium L'Her. (Geraniaceae). Acta Botanica Gallica: Botany Letters 1995; 142(1): 31-35.

[145] Al-Snafi AE. A review on Erodium cicutarium: A potential medicinal plant. Indo Am J P Sci 2017; 4(01): 110-116.

[146] Al-Snafi AE. Chemical constituents and pharmacological activities of Milfoil (Achillea santolina) - A Review. Int J Pharm Tech Res 2013; 5(3): 1373-1377. 
[147] Rauwald HW, Brehm $\mathrm{H}$ and Odenthal KP. The involvement of $\mathrm{Ca}^{2+}$ channel blocking mode of action in the pharmacology of Ammi visnaga fruits. Planta Medica 1994; 60: 101-105.

[148] Kong D, Zhang WZ, XiaoL and Yuan D. Safflower yellow injection combined with conventional therapy in treating unstable angina pectoris: a meta-analysis. Journal of Traditional Chinese Medicine 2013; 33(5): 553-561.

[149] Balbaa SI, Zaki AY, Abdel-Wahab SM, El-Denshary ESM and Motazz-Bellah M. Preliminary phytochemical and pharmacological investigations of the roots of different varieties of Cichorium intybus. Planta Med 1973; 24(6): 133-144.

[150] Boskabady MH, Shafei MN, Shakiba A and Sefidi HS. Effect of aqueous-ethanol extract from Crocus sativus(saffron) on guinea-pig isolated heart. Iranian Congress of Physiology and Pharmacology 2007, 18, http://en.seminars.sid.ir/ViewPaper.aspx?ID=760

[151] Joukar S . Electrocardiogram alterations following one- week consumption of Crocus sativus L.(Saffron). EXCLI Journal 2012; 11: 480-486.

[152] Najafi M, Nazemiyeh H, Ghavimi H, Gharakhani A and Garjani A. Effects of hydroalcoholic extract of Cynodon dactylon (L) pers on ischemia/reperfusion-induced arrhythmias. DARU 2008; 16 (4): 233-238.

[153] Jain RC. Effect of garlic on serum lipids, coagulability and fibrinolytic activity of blood. Am J Clin Nutr 1977; 30: 1380-1381.

[154] Bordia A, Verma SK, Vyas AK et al. Effect of essential oil of onion and garlic on experimental atherosclerosis in rabbits. Atherosclerosis 1997; 26: 379-386.

[155] Chang ML W, Johnson MA. Effect of garlic on carbohydrate metabolism and lipid synthesis in rats. J Nutr 1980; 110: 931-936.

[156] Kamanna VS, Chandrasekhara N. Hypocholesteromic activity of different fractions of garlic. Ind J Medical Res 1984; 79: 580-583.

[157] Mand JK, Gupta PP, Soni GL et al. Effect of garlic on experimental atherosclerosis in rabbits. Ind Heart J 1985; 37: 183-188.

[158] Betz E, and Weidler R. Die Wirkung von Knoblauchextrakt auf die atheerogenese bei kaninchen. In: Betz E, editor. Die anwendung aktueller methoden in der arteriosklerose. Forschung 1989: 304-311.

[159] Rajasree CR, Rajmohan T and Agusti KT. Biochemical effects of garlic on lipid metabolism in alcohol fed rats. Ind J Exp Biol 1999; 37: 243-247.

[160] Mathew BC and Daniel RS. Hypolipidemic effect of garlic protein substituted for caseinin diet of rats compared to those of garlic oil. Ind J Exp Biol 1996; 34: 337-340.

[161] Qureshi AA, Din ZZ, Abuirameileh N et al. Suppression of avian hepatic lipid metabolism by solvent extracts of garlic: impact on serum lipids. J Nutr 1983; 113: 1746-1755.

[162] Kamanna VS and Chandrasekhara N. Effect of garlic on serum lipoproteins cholesterol levels in albino rats rendered hypercholesteremic by feeding cholesterol. Lipids 1982; 17: 483-488.

[163] Chi MS. Effect of garlic products on lipid metabolism in cholesterol-fed rats. Proc Soc Exp Biol Med 1982; 171: 174-178.

[164] Chi MS, Koh ET and Stewart TJ. Effect of garlic on lipid metabolism in rats fed cholesterol or lard. J Nutr 1982; 112: 241-248.

[165] Gebhardt R. Multiple inhibitory effects of garlic extracts on cholesterol biosynthesis in hepatocytes. Lipids 1993; 28: 613-619.

[166] Saxena KK, Gupta B, Kulshreshtha VK et al. Effect of garlic treatment on isoprenaline-induced myocordial necrosis in albino rats. Indian J Physiol Pharmacol 1980; 24: 233-236.

[167] Bordia A. Effect of garlic and blood lipids in patients with coronary heart disease. Am J Clin Nutr 1981; 34: 2100-2103.

[168] Kojuri J, Vosoughi AR and Akrami M. Effects of Anethum graveolens and garlic on lipid profile in hyperlipidemic patients. Lipids Health Dis 2007; 6: 5.

[169] Sainani GS, Desai DB, Gorhe NH et al. Effect of dietary garlic and onion on serum lipid profile in jain community. Indian J Med Res 1979; 69: 776-780.

[170] Kiesewetter H, Jung F, Jung EM et al. Effects of garlic coated tablets in peripheral arterial occlusive disease. Clin Investig 1993; 71: 383-386.

[171] Siegel G, Walter A, Engel S et al. Pleiotropic effects of garlic. Wien Med Wochenschr 1999; 149: $217-$ 224.

[172] Bhushan S, Sharma SP, Singh SP et al. Study of the hypocholesterolemic effect of onion (Allium cepa) on normal human beings. Indian Med Gaz 1979; 16: 249-251. 
[173] Kim K, Kim H, Kwon J, Lee S, Kong H, Im SA, Lee YH, Lee YR, Oh ST, Jo T H, Park YI, Lee CK and Kim K. Hypoglycemic and hypolipidemic effects of processed Aloe vera gel in a mouse model of noninsulin- dependent diabetes mellitus. Phytomedicine 2009; 16(9): 856-863.

[174] Al-Snafi AE. The pharmacological importance of Aloe vera- A review. International Journal of Phytopharmacy Research 2015; 6(1) : 28-33.

[175] Agarwal OP. Prevention of atheromatous heart disease. Angiolog1985; 36(8). Presented at the 31st Annual Meeting, American College of Angiology and 26th Annual Meeting, International College of Angiology 1984.

[176] Al-Snafi AE. The pharmacological activities of Alpinia galangal - A review. International Journal for Pharmaceutical Research Scholars 2014; 3(1-1): 607-614.

[177] Achuthan CR and Padikkala J. Hypolipidemic effect of Alpinia galangal (Rasna) and Kaempferia galangal Kachoori). Indian J Clin Biochem 1997; 12(1): 55-58.

[178] Jantan I, Rafi AA, and Jali J. Platelet-activating factor (PAF) receptor-binding antagonist activity of Malaysian medicinal plants. Phytomedicine 2005; 12(6): 88-92.

[179] Harvengt C and Desager J P. HDL-cholesterol increase in normolipaemic subjects on khellin: a pilot study. International Journal of Clinical Pharmacology Research 1983; 3: 363-366.

[180] Yazdanparast R and Bahramikia S. Improvement of liver antioxidant status in hyper- cholesterolamic rats treated with A. graveolens extracts. Pharmacologyonline 2007; 3: 88-94.

[181] Yazdanparast R and Alavi M. Antihyperlipidaemic and anti-hypercholesterolaemic effects of Anethum graveolens leaves after the removal of furocoumarins. Cytobios 2001; 105: 185-191.

[182] Yazdanparast R., and Bahramikia S. Evaluation of the effect of Anethum graveolens L. crude extracts on serum lipids and lipoproteins profiles in hypercholesterolaemic rats. DARU 2008; 16(2): 88-94.

[183] Al-Snafi AE. The pharmacological importance of Anethum graveolens- A review. International Journal of Pharmacy and Pharmaceutical Sciences 2014; 6(4): 11-13.

[184] Tsi D, Das NP and Tan BK. Effects of celery (A. graveolens) extract on lipid parameters of rats fed a high fat diet. Planta Med 1995; 6: 18-21.

[185] Tsi D and Tan BK. Effects of celery extract and 3-N-butylphthalide on lipid levels in genetically hypercholesterolaemic (RICO) rats. Clin Exp Pharmacol Physiol 1996; 23(3): 214-217.

[186] Tsi D and Tsi BKH. The mechanism underlying the hypocholesterolemic activity of aqueous celery extract, its butanol and aqueous fractions in genetically hypocholesterolemic rats. J Life Sci 2000; 66: 755-767.

[187] Kamal M, Adel MA, Ahmad D and Talal A. Hypolipidemic effects of seed extract of celery (Apium graveolens) in rats. Phcog Mag 2009; 5: 301-305.

[188] Le QT and Elliott WJ. Dose response relationship of blood pressure and serum cholesterol to 3-nbutylphthalide, a component of celery oil. Clin Res 1991; 39: 750A.

[189] Ahmed, QS , and Sayedda K . Effect of celery (Apium graveolens) seeds extract on protease inhibitor (Ritonavir) induced dyslipidemia. NJIRM 2012; 3(1): 52-56.

[190] Bansode RR, Randolph P, Hurley S, and Ahmedna M. Evaluation of hypolipidemic effects of peanut skin-derived polyphenols in rats on Western-diet. Food Chem 2012; 135(3): 1659-1666.

[191] Al-Snafi AE. Chemical constituents and pharmacological activities of Arachis hypogaea - A review. International Journal for Pharmaceutical Research Scholars 2014; 3(1-1): 615-623.

[192] Tamura T, Inoue N, Shimizu-Ibuka A, Tadaishi M, Takita T, Arai S, and Mura K. Serum cholesterol reduction by feeding a high-cholesterol diet containing a lower-molecular-weight polyphenol fraction from peanut skin. Biosci Biotechnol Biochem 2012; 76(4): 834-837.

[193] Emekli-Alturfan E, Kasikci E and Yarat, A. Peanut (Arachis hypogaea) consumption improves Glutathione and HDL-cholesterol levels in experimental diabetes. Phytotherapy Research 2008; 22(2): 180-184.

[194] Sobolev VS, Khan SI, Tabanca N, Wedge DE, Manly SP, Cutler SJ, Coy MR , Becnel JJ , Neff SA and Gloer JB. Biological Activity of Peanut (Arachis hypogaea) Phytoalexins and selected natural and synthetic stilbenoids. J Agric Food Chem 2011; 59: 1673-1682.

[195] Lappano R, Rosano C, Madeo A, Albanito L, Plastina P, Gabriele B, Forti L, Stivala LA, Iacopetta D, Dolce V, Ando S, Pezzi V and Maggiolini M. Structure-activity relationships of resveratrol and derivatives in breast cancer cells. Mol Nutr Food Res 2009; 53: 845-858.

[196] Zhu X, Zhang W, Pang X, Wang J, Zhao J and Qu W. Hypolipidemic Effect of $n$-Butanol Extract from Asparagus officinalis L. in mice fed a high-fat diet. Phytother Res 2011; 25(8): 1119-1124. 
[197] Zhu X, Zhang W, Zhao J, Wang J and Qu W. Hypolipidaemic and hepatoprotective effects of ethanolic and aqueous extracts from Asparagus officinalis Asparagus officinalis L. by products in mice fed a highfat diet. Journal of the Science of Food and Agriculture 2010; 90(7):1129-1135.

[198] Al-Snafi AE. The pharmacological importance of Asparagus officinalis - A review. Journal of Pharmaceutical Biology 2015; 5(2): 93-98.

[199] Saltzman E, Das S K and Lichtenstein A H. An oat-containing hypocaloric diet reduces systolic blood pressure and improves lipid profile beyond effects of weight loss in men and women. J Nutr 2001; 131: 1465-1470.

[200] Al-Snafi AE. The nutritional and therapeutic importance of Avena sativa - An Overview. International Journal of Phytotherapy 2015; 5(1): 48-56.

[201] Sobotka W, Flis M, Antoszkiewicz Z, Lipiński K and Zduńczyk Z. Effect of oat by-product antioxidants and vitamin $\mathrm{E}$ on the oxidative stability of pork from pigs fed diets supplemented with linseed oil. Arch Anim Nutr 2012; 66(1): 27-38.

[202] Lin N, Li Y, Tang L, Shi J and Chen Y. In vivo effect of oat cereal $\beta$-glucan on metabolic indexes and satiety-related hormones in diet-induced obesity C57-Bl mice. Mol Nutr Food Res 2013; 57(7): 12911294.

[203] El Khoury D, Cuda C, Luhovyy BL, and Anderson GH. Beta glucan: health benefits in obesity and metabolic syndrome. Journal of Nutrition and Metabolism 2012; Article ID 851362, http://dx.doi.org/10.1155/2012/851362

[204] Chang HC, Huang CN, Yeh DM, Wang SJ, Peng CH and Wang CJ. Oat prevents obesity and abdominal fat distribution, and improves liver function in humans. Plant Foods Hum Nutr 2013; 68(1): 18-23.

[205] Thongoun P, Pavadhgul P, Bumrungpert A, Satitvipawee P, Harjani Y and Kurilich A. Effect of oat consumption on lipid profiles in hypercholesterolemic adults. J Med Assoc Thai 2013; 96 (5): S25-S32.

[206] Reddy MV, Reddy MK, Gunasekar D, Caux C and Bodo B. A flavanone and a dihydro dibenzoxepin from Bauhinia variegata. Phytochemistry 2003; 64: 879-882.

[207] Al-Snafi AE. The Pharmacological importance of Bauhinia variegata. A Review. Journal of Pharma Sciences and Research 2013; 4(12): 160-164.

[208] Kumar D, Parcha V, Maithani A and Dhulia I. Effect and evaluation of antihyperlipidemic activity of fractions of total methanol extract of Bauhinia variegata (Linn.) leaves on Triton WR-1339 (Tyloxapol) induced hyperlipidemic rats. Int J Res Pharm Sci 2011; 2(4): 493-497.

[209] Balamurugan G and Muralidharan P. Antiobesity effect of Bauhinia variegata bark extract on female rats fed on hypercaloric diet. Bangladesh J Pharmacol 2010; 5: 8-12.

[210] Morikawa T, Li X, Nishida E, Nakamura S, Ninomiya K, Matsuda H, Ody Y, Muraoka O and Yoshikawa M. Perennisosides I-VII, acylated triterpene saponins with antihyperlipidemic activities from the flowers of Bellis perennis. J Nat Prod 2008; 71: 828-835.

[211] Morikawa T, Muraoka O and Yoshikawa M. Pharmaceutical food science: search for anti-obese constituents from medicinal foods-anti-hyperlipidemic saponin constituents from the flowers of Bellis perennis. Yakugaku Zasshi 2010; 130(5): 673-678.

[212] Al-Snafi AE. The Pharmacological importance of Bellis perennis - A review. International Journal of Phytotherapy 2015; 5(2): 63-69.

[213] Amirthaveni M and Priya V. Hypoglycemic and hypolipidemic effect of ash gourd (Benincasa hispida) and curry leaves (Murraya koenigii). International Journal of Current Research 2011; 3(8): 37-42.

[214] Al-Snafi AE. The Pharmacological Importance of Benincasa hispida. A review. Int Journal of Pharma Sciences and Research 2013; 4(12): 165-170.

[215] Mirzaie H, Johari H, Najafian M and Kargar H. Effect of ethanol extract of root turnip (Brassica rapa) on changes in blood factors HDL, LDL, triglycerides and total cholesterol in hypercholesterolemic rabbits. Advances in Environmental Biology 2012; 6(10): 2796-2801.

[216] Bang MH, Lee DY, Oh YJ, Han MW, Yang HJ, Chung HG, Jeong TS, Lee KT, Choi MS and Baek NI. Development of biologically active compounds from edible plant sources XXII. Isolation of indoles from the roots of Brassica campestris ssp rapa and their hACAT inhibitory activity. J Korean Soc Appl Biol Chem 2008; 51(1): 65-69.

[217] An S, Han JI, Kim MJ, Park JS, Han JM, Baek NI, Chung HG, Choi MS, Lee KT and Jeong TS. Ethanolic extracts of Brassica campestris spp. rapa roots prevent high-fat diet-induced obesity via beta3adrenergic regulation of white adipocyte lipolytic activity. J Med Food 2010; 13(2): 406-414.

[218] Gupta M, Mazumder UK, Sambath KR, Thangavel S, and Vamsi M L M. Antitumor activity and antioxidant status of Caesalpinia bonducella against Ehrlich ascites carcinoma in Swiss albino mice. J Pharmacol Sci 2004; 94: 177-184. 
[219] Bhaskar VH and Ajay SS. Antihyperglycemic and antihyperlipidaemic activities of root extracts of Calotropis procera (Ait.) R.Br on streptozotocin. Jordan Journal of Biological Sciences 2009; 2(4): 177180.

[220] Lekhmici A, Benzidane N, Imane K, Noureddine C, Seddik K, and Abderrahmane B. Comparison between Polyphenol contents and antioxidant activities of different parts of Capparis spinosa $\mathrm{L}$. The 3rd International Symposium on the Medicinal Plants, Their Cultuvation and Aspects of uses, Beit Zaman Hotel \& Resort, Petra, 2012.

[221] Al-Snafi AE. The chemical constituents and pharmacological effects of Capparis spinosa - An overview. Indian Journal of Pharmaceutical Science and Research 2015; 5(2): 93-100.

[222] Baek J, Lee J, Kim K, Kim T, Kim D, Kim C, Tsutomu K, Ochir S, Lee K, Ho Park C, Lee Y and Choe M. Inhibitory effects of Capsicum annuum L. water extracts on lipoprotein lipase activity in 3T3-L1 cells. Nutrition Research and Practice 2013; 7(2): 96-102.

[223] Al-Snafi AE. The pharmacological importance of Capsicum species (Capsicum annuum and Capsicum frutescens) grown in Iraq. Journal of Pharmaceutical Biology 2015; 5(3): 124-142.

[224] Saghir MR , Sadiq S, Nayak S and Tahir MU. Hypolipidemic effect of aqueous extract of Carum carvi (black Zeera) seeds in diet induced hyperlipidemic rats. Pak J Pharm Sci 2012; 25(2): 333-337.

[225] Al-Snafi AE. The chemical constituents and pharmacological effects of Carum carvi - A review. Indian Journal of Pharmaceutical Science and Research 2015; 5(2): 72-82.

[226] Haidari F, Seyed-Sadjadi N, Taha-Jalali M and Mohammed-Shahi M. The effect of oral administration of Carum carvi on weight, serum glucose, and lipid profile in streptozotocin-induced diabetic rats. Saudi Med J 2011; 32(7): 695-700.

[227] Lemhadri A, Hajji L, Michel JB and Eddouks M. Cholesterol and triglycerides lowering activities of caraway fruits in normal and streptozotocin diabetic rats. J Ethnopharmacol 2006; 106(3): 321-326.

[228] Arpornsuwan T, Changsri K, Roytrakul S and Punjanon T. The effects of the extracts from Carthamus tinctorius L. on gene expression related to cholesterol metabolism in rats. Songklanakarin J Sci Technol 2010; 32(2): 129-136.

[229] Al-Snafi AE. The chemical constituents and pharmacological importance of Carthamus tinctorius - An overview. Journal of Pharmaceutical Biology 2015; 5(3): 143-166.

[230] Katsuda S, Suzuki K, Koyama N, Takahashi M, Miyake M, Hazama A and Takazawa K. Safflower seed polyphenols (N-(p-coumaroyl)serotonin and $\mathrm{N}$-feruloylserotonin) ameliorate atherosclerosis and distensibility of the aortic wall in Kurosawa and Kusanagi-hypercholesterolemic (KHC) rabbits. Hypertens Res 2009; 32(11): 944-949.

[231] Sunday AG, Ifeanyi OE and Eucharia UC. The effects of casuarina bark on lipid profile and random blood sugar level in albino rats. Journal of Dental and Medical Sciences 2014; 13(4): 11-15.

[232] Al-Snafi AE. The pharmacological importance of Casuarina equisetifolia - An overview. International Journal of Pharmacological Screening Methods 2015; 5(1): 4-9.

[233] Sriram N. Antidiabetic and antihyperlipidemic activity of bark of Casuarina equisetifolia on streptozocin induced diabetic rats. International Journal of Pharmacy Review and Research 2011; 1(1): 4-8.

[234] Shimoda H, Tanaka J, Takahara Y, Takemoto K, Shan SJ and Su MH. The hypocholesterolemic effects of Cistanche tubulosa extract, a Chinese traditional crude medicine, in mice. Am J Chin Med 2009; 37(6): 1125-1138.

[235] Rahbar AR and Nabipour I. The hypolipidemic effect of Citrullus colocynthis on patients with hyperlipidemia. Pak J Biol Sci 2010; 13(24):1202-1207.

[236] Al-Snafi AE. Chemical constituents and pharmacological effects of Citrullus colocynthis - A review. IOSR Journal of Pharmacy 2016; 6(3): 57-67.

[237] Yaghmaie P, Parivar K and Haftsavar M. Effects of Citrus aurantifolia peel essential oil on serum cholesterol levels in Wistar rats. Journal of Paramedical Sciences (JPS) 2011; 2(1):29-32.

[238] Akinboyewa OM. Effect of Citrus aurantifolia on hepatic lipidomics in female albino rats. BSc thesis, Department of Biochemistry, College of Natural Sciences, Federal University of Agriculture, Abeokuta 2012.

[239] Hiramitsu M, Shimada Y, Kuroyanagi J, Inoue T, Katagiri T, Zang L, Nishimura Y, Nishimura N and Tanaka T. Eriocitrin ameliorates diet-induced hepatic steatosis with activation of mitochondrial biogenesis. Sci Rep 2014; 4: 3708.

[240] Menichini F, Tundis R, Loizzo MR, Bonesi M, Liu B, Jones P, Persaud SJ, Mastellone V, Lombardi P, Houghton PJ, Avallone L and Menichini F. C. medica cv Diamante peel chemical composition and influence on glucose homeostasis and metabolic parameters. Food Chemistry 2011; 124(3): 1083-1089. 
[241] Solanki YB and Jain SM. Antihyperlipidemic activity of Clitoria ternatea and Vigna mungo in rats. Pharmaceutical Biology 2010; 48(8): 915-923.

[242] Al-Snafi AE. Pharmacological importance of Clitoria ternatea - A review. IOSR Journal of Pharmacy 2016; 6(3): 68-83.

[243] Kousar S, Jahan N, Khalil-ur-Rehman and Nosheen S. Antilipidemic activity of Coriandrum sativum. Bioscience Research 2011; 8(1): 8-14.

[244] Joshi SC, Sharma N and Sharma P. Antioxidant and lipid lowering effect of Coriandrum sativum in cholesterol fed rabbits. Int J Pharm Pharm Sci 2012; 4(3):231-234.

[245] Dhanapakiam P, Joseph JM, Ramaswamy VK, Moorthi M and Kumar AS. Coriandor seeds have a cholesterol-lowering action. J Environ Biol 2008; 29(1):53-56.

[246] Chithra V and Leelamma S. Hypolipidemic effect of coriander seeds (Coriandrum sativum): mechanism of action. Plant Foods Hum Nutr 1997; 51(2):167-172.

[247] Sheng L, Qian Z, Zheng S and Xi L. Mechanism of hypolipidemic effect of crocin in rats: crocin inhibits pancreatic lipase. Eur J Pharmacol 2006; 543: 116-122.

[248] Zheng S, Qian Z, Tang F and Sheng L. Suppression of vascular cell adhesion molecule-1 expression by crocetin contributes to attenuation of atherosclerosis in hypercholesterolemic rabbits. Biochem Pharmacol 2005; 70: 1192-1199.

[249] Gainer JW and Chisolm GM. Oxygen diffusion and atherosclerosis. Atherosclerosis 1974; 19:135-138.

[250] He S, Qian Z, Tang F, Wen N, Xu G and Sheng L. Effect of crocin on experimental atherosclerosis in quails and its mechanisms. Life Sciences 2005; 77: 907-921.

[251] Verma SK and Bordia A. Antioxidant property of saffron in man. Indian J Med Sci 1998; 52: $205-207$.

[252] Gout B, Bourges C and Paineau-Dubreuil S. Satiereal, a Crocus sativus L extract, reduces snacking and increases satiety in a randomizedplacebo-controlled study of mildly overweight, healthy women. Nutr Res 2010; 30(5): 305-313.

[253] Kumar DS, David B, Harani A and Vijay B. Role of an ethanolic extract of Crotalaria juncea L. on highfat diet-induced hypercholesterolemia. Sci Pharm 2014; 82(2): 393-409.

[254] Al-Snafi AE. The contents and pharmacology of Crotalaria juncea- A review. IOSR Journal of Pharmacy 2016; 6(6): 77-86.

[255] Harikumar K, Niveditha B, Kumar MRB, Monica K and Gajendra B. Anti- hyperlipidemic activity of alcoholic and methanolic extracts of Crotolaria juncea in Triton-WR 1339 induced hyperlipidemia. International Journal of Phytopharmacology 2012; 3(3): 256-262.

[256] Prasad J, Singh VK, Shrivastava A, Chaturvedi U, Bhatia G, Arya KR, Awasthi SK and Narender T. Antidyslipidemic and antioxidant activity of an unusual amino acid (2-amino-5-hydroxyhexanoic acid) isolated from the seeds of Crotalaria juncea. Phytomedicine 2013; 21(1):15-19.

[257] Sreedhar KS. Evaluation of Anti-obesity activities of Crotalaria juncea L. in albino rats. MSc thesis, Gautham College of Pharmacy 2011.

[258] Shirke SS and Jagtap AJ. Effects of methanolic extract of Cuminum cyminum on total serum cholesterol in ovariectomized rats. Indian J Pharmacol 2009; 41(2): 91-93.

[259] Al-Snafi AE. The pharmacological activities of Cuminum cyminum - A review. IOSR Journal of Pharmacy 2016; 6(6): 46-65

[260] Zare R, Heshmati F, Fallahzadeh H and Nadjarzadeh A. Effect of cumin powder on body composition and lipid profile in overweight and obese women. Complement Ther Clin Pract 2014; 20(4): 297-301.

[261] Samani KG and Farrokhi E. Effects of cumin extract on oxLDL, paraoxanase 1 activity, FBS, total cholesterol, triglycerides, HDL-C, LDL-C, Apo A1, and Apo B in in the patients with hypercholesterolemia. Int J Health Sci (Qassim) 2014; 8(1):39-43.

[262] Taghizadeh M, Memarzadeh MR, Asemi Z and Esmaillzadeh A. Effect of the Cuminum cyminum L intake on weight loss, metabolic profiles and biomarkers of oxidative stress in overweight subjects: A randomized double-blind placebo-controlled clinical trial. Ann Nutr Metab 2015; 66(2-3):117-124.

[263] Karkabounas S, Kiortsis DN, Zelovitis J, Skafida P, Demetzos C, Malamas M, Elisaf M and Evangelou A. Effects of Cupressus sempervirens cone extract on lipid parameters in Wistar rats. In Vivo 2003;17(1):101-103.

[264] Al-Snafi AE. Medical importance of Cupressus sempervirens- A review. IOSR Journal of Pharmacy 2016; 6(6): 66-76.

[265] Abliz A, Aji Q, Abdusalam E, Sun X, Abdurahman A, Zhou W, Moore N and Umar A. Effect of Cydonia oblonga Mill leaf extract on serum lipids and liver function in a rat model of hyperlipidaemia. J Ethnopharmaco 2014; 151(2): 970-944. 
[266] Al-Snafi AE. The medical importance of Cydonia oblonga- A review. IOSR Journal of Pharmacy 2016; 6(6): 87-99.

[267] Khademi F. The efficay of quince leave extract on atherosclerotic plaques induced by atherogenic diet in coronary and aorta, hyperlipidemia and liver in rabbit. MSc thesis, Tabriz University of Medical Sciences, Tabriz, Iran 2009.

[268] Chandratre RS, Chandarana S and Mengi SA. Lipid lowering activity of alcoholic extract of Cyperus rotundus. IJRPC 2011; 1(4): 1042- 1045.

[269] Lemaure B, Touché A, Zbinden I, Moulin J, Courtois D, Macé K and Darimont C. Administration of Cyperus rotundus tubers extract prevents weight gain in obese Zucker rats. Phytother Res 2007; 21: 724730.

[270] Poudyal H, Panchal S and Brown L. Comparison of purple carrot Juice and $\beta$-carotene in a highcarbohydrate, high-fat diet-fed rat model of the metabolic syndrome. British Journal of Nutrition 2010; 104: 1322-1332.

[271] Nicolle C, Cardinault N, Aprikian O, Busserolles J, Grolier P, Rock E, Demigné C, Mazur A, Scalbert A, Amouroux P and Rémésy C. Effect of carrot intake on cholesterol metabolism and on antioxidant status in cholesterol-fed rat. European Journal of Nutrition 2003; 42: 254-261.

[272] Ramakrishna V, Rani PJ and Rao PR. Hypocholesterolemic effect of diet supplemented with Indian bean (Dolichos lablab L. var lignosus) seeds. Nutrition \& Food Science 2007; 37(6): 452 - 456.

[273] Al-Snafi AE. The pharmacology and medical importance of Dolichos lablab (Lablab purpureus)- A review. IOSR Journal of Pharmacy 2017; 7(2): 22-30.

[274] Pavani M, Ramadurg B and Varshitha C. Anti-obesity activities of hydroalcoholic extract of Echinochloa crusgalli (L.) P. Beauv grains in albino rats. Research Journal of Pharmacology and Pharmacodynamics 2014; 6(1): 13-20.

[275] Al-Snafi AE. Pharmacology of Echinochloa crus-galli - A review. Indo Am J P Sci 2017; 4(01): 117 122.

[276] Kumar DS, Banji D and Harani A. Antihypercholesterolemic effect of Echinochloa crusgalli. National Conference on (New trends in molecular medicine and pharmacogenomics)- India 2013.

[277] Al-Awwadi NAJ. Effects of Achillea Santolina extracts and fractions on human platelet aggregation in vitro and on rat arteriovenous shunt thrombosis in vivo. Thi-Qar Medical Journal 2010; 4(3): 131-141.

[278] Breu W, Dorsch W. Allium cepa L. (Onion): Chemistry, analysis and pharmacology. In: Wagner H, Farnsworth NR, eds. Economic and medicinal plants research 1994; 6: 115-147.

[279] Srivastava KC. Aqueous extracts of onion, garlic and ginger inhibit platelet aggregation and alter arachidonic acid metabolism. Biomedica biochimica acta 1984; 43: S335-S346.

[280] Chauhan LS et al. Effect of onion, garlic and clofibrate on coagulation and fibrinolytic activity of blood in cholesterol fed rabbits. Indian Medical Journal 1982; 76: 126-127.

[281] Augusti KT. Therapeutic values of onion (Allium cepa L.) and garlic (Allium sativum L.). Indian J Exp Biol 1996; 34(7):634-640.

[282] Makheja AN, Vanderhoek JY, Bailey JM. Inhibition of platelet aggregation and thromboxane synthesis by onion and garlic. Lancet 1979; 1: 781 .

[283] Ariga $\mathrm{T}$ and Oshiba S. Effects of the essential oil components of garlic cloves on rabbit platelet aggregation. Igaku to seibutsugak 1981; 102: 169-174.

[284] Vanderhoek JY, Makheja AN and Bailey JM. Inhibition of fatty acid oxygenases by onion and garlic oils. Evidence for the mechanism by which these oils inhibit platelet aggregation. Biochemical Pharmacology 1980; 29: 3169-3173.

[285] Dorsch W, Ettl M, Hein G et al. Anti-asthmatic effects of onions: Inhibition of platelet-activating factorinduced bronchial construction by onion oils. Int Arch Allergy Appl Immunol 1987; 82: 535-536.

[286] Dorsch W, Wagner H, Bayer T et al. Antiasthmatic effects of onions: Alk(en)ylsulfinothic acid alk(en)ylesters inhibit histamine release, leukotriene and thromboxane biosynthesis in vitro and counteract PAF- and allergen-induced bronchial obstruction in vivo. Biochem Pharmacol 1987; 37: 4479-4485.

[287] Ross I A. Medicinal Plants of the world: Chemical Constituents, Traditional and Modern Medicinal Uses, Humana Press, Totowa 2001.

[288] Mohammad SF and Woodward SC. Characterization of a potent inhibitor of platelet aggregation and release reaction isolated from Allium sativum (garlic). Thromb Res 1986; 44: 793-796.

[289] Mohammad SF, Brown S, Chuang HYK et al. Isolation, characterization, identification and synthesis of an inhibitor of platelet function from Allium sativum. Fed Proc 1980; 39: 543A. 
[290] Srivastava KC and Justesen U. Isolation and effect of some garlic components on platelet aggregation and metabolism of arachidonic acid in human blood platelets. Wien Klin Wochenschr 1989; 8: 293-299.

[291] Makheja AN and Bailey JM. Antiplatelet constituents of garlic and onion. Agents and actions 1990; 29: 360-363.

[292] WHO monographs on selected medicinal plants, WHO Library Cataloguing in Publication Data, 2007.

[293] Srivastava KC. Effect of aqueous extract of onion, garlic and ginger on platelet aggregation and metabolism of arachidonic acid in blood vascular system: in vitro study. Prostaglandins Leukot Med 1984; 13: 227-235.

[294] Kiesewetter H, Jung F, Wolf S et al. Effect of garlic on thrombocyte aggregation, microcirculation, and other risk factors. International Journal of Clinical pharmacology 1981; 29: 151-155.

[295] Bordia AK, Joshi HK, Sanadhya YK and Bhu N. Effect of essential oil of garlic on serum fibrinolytic activity in patients with coronary heart disease. Atherosclerosis 1977; 28: 155-159.

[296] Harenberg J, Giese C, and Zimmermann R. Effect of dried garlic on blood coagulation, fibrinolysis, platelet aggregation and serum cholesterol levels in patient with hyperlipoproteinemia. Atherosclerosis 1988; 74: 247-249.

[297] Jung F, Wolf S, Kisewetter H et al. Wirkung von knoblauch auf die fließfahigkeit des Blutes, Ergebnisse placebokontrolllierter Pilotstudien an gesunden Probanden. Natur und Ganzheitsmed 1989; 7: 216-221.

[298] Jung F, Jung EM, Pundir G and Kiesewetter H. Effect of different garlic preparations on the fluidity of blood, fibrinolytic activity and peripheral microcirculation in comparison with placebo. Planta Med 1990; 56: 668.

[299] Lawson LD. Bioactive organosulfur compound of garlic and garlic products: role in reducing blood lipids. In: Kinghorn AD, Balandrin MF, editors. Human medicinal agents from plants. Washington. American Chemical Society 1993: 306-330.

[300] MacDonald JA, Marchand ME and Langler RF. Improving upon the in vitro biological activity of antithrombotic disulfide. Blood Coagul Fibrinolysis 2004; 15: 447-450.

[301] Srivastava KC. Evidence for the mechanism by which garlic inhibits platelet aggregation. Prostaglandins Leukot Med 1986; 22: 313-321.

[302] Srivastava KC and Tyagi OD. Effects of a garlic derived principle (ajoene) on aggregation and arachidonic acid metabolism in human blood platelets. Prostaglandins Leukot Essent Fatty Acids, 1986; 49: 587-595.

[303] Al-Snafi AE. The Pharmaceutical importance of Althaea officinalis and Althaea rosea: A Review. Int J Pharm Tech Res 2013; 5(3):1387-1385.

[304] Teng CM et al. Inhibition of platelet aggregation by apigenin from Apium graveolens. Asia Pasific J Pharmacol 1989;1: 85-89.

[305] Al-Snafi AE. The Pharmacology of Apium graveolens- A review. International Journal for Pharmaceutical Research Scholars 2014; 3(1-1): 671-677.

[306] Khare CP . Indian herbal remedies. Springer - Verlag, Berlin , Heidelberg, New York, 2004.

[307] $\mathrm{Wu} \mathrm{T,} \mathrm{Ou} \mathrm{L,} \mathrm{and} \mathrm{Teng} \mathrm{C.} \mathrm{Aristolochic} \mathrm{acids,} \mathrm{aristolactam} \mathrm{alkaloids} \mathrm{and} \mathrm{amides} \mathrm{from} \mathrm{Aristolochia}$ kankauensis. Phytochemistry 1994; 36: 1063-1068.

[308] Goun E, Cunningham G, Solodnikov S, Krasnykch O, and Miles H. Antithrombin activity of some constituents from Origanum vulgare. Fitoterapia 2002; 73: 692-694.

[309] Liggieri C, Arribére MC, Trejo SA, Canals F, Avilés FX and Priolo NS. Purification and biochemical characterization of asclepain CI from the latex of Asclepias curassavica L. Protein J 2004; 23(6): 403411.

[310] Karpagam N, Viswanathan S and Prabhu S. Biochemical and In silico clotting activity of latex from Asclepias curassavica L. Int J Pharm Bio Sci 2013; 4(4): (B) 542 - 552.

[311] Shivaprasad HV, Riyaz M, Venkatesh Kumar R, Dharmappa KK, Tarannum S, Siddesha JM, Rajesh R and Vishwanath BS. Cysteine proteases from the Asclepiadaceae plants latex exhibited thrombin and plasmin like activities. J Thromb Thrombolysis 2009; 28(3): 304-308.

[312] Shivaprasad HV, Rajesh R, Nanda BL, Dharmappa KK and Vishwanath BS. Thrombin like activity of Asclepias curassavica L. latex: Action of cysteine proteases. J Ethnopharmacology 2009; 123: 106-109.

[313] Ercisli S. Clinical justification of ethnomedicinal use of Brassica rapa in cardiovascular diseases. Exp Clin Cardiol 2014; 20(7): 764-783.

[314] Ramos MV, Viana CA, Silva AF, Freitas CD, Figueiredo IS, Oliveira RS, Alencar NM, Lima-Filho JV and Kumar VL. Proteins derived from latex of $C$. procera maintain coagulation homeostasis in septic mice and exhibit thrombin- and plasmin-like activities. Naunyn Schmiedebergs Arch Pharmacol 1999; 385(5): 455-463. 
[315] Al-Snafi AE. Bioactive components and pharmacological effects of Canna indica- An overview. International Journal of Pharmacology and Toxicology 2015; 5(2):71-75.

[316] Khare CP. Indian medicinal plants - An illustrated dictionary. Springer Science and Business Media, LLC, 2007.

[317] Sheikh Anwar M, Khan IN, Sarkar MI, Barua S, Kamal ATM and Hosen SM Z. Thrombolytic and cytotoxic effect of different herbal extracts. IJPSR 2011; 2(12): 3118-3121.

[318] Adams MJ, Ahuja KD and Geraghty DP. Effect of capsaicin and dihydrocapsaicin on in vitro blood coagulation and platelet aggregation. Thromb Res 2009; 124: 721-723.

[319] Hogaboam CM, Wallace JL. Inhibition of platelet aggregation by capsaicin. An effect unrelated to actions on sensory afferent neurons. Eur J Pharmacol 1991; 202: 1991, 129-131.

[320] Li HX, Han SY, Wang XW, Ma X, Zhang K, Wang L, Ma ZZ and Tu PF. Effect of the carthamins yellow from Carthamus tinctorius L. on hemorheological disorders of blood stasis in rats. Food Chem Toxicol 2009; 47(8): 1797-1802.

[321] Al-Snafi AE. Cardiovascular effects of Carthamus tinctorius: A mini-review. Asian Journal of Pharmaceutical Research 2015; 5(3): 199-209.

[322] Huang D, Lu Y, Luo X, Shi L, Zhang J, Shen J, Bao M, Song L, Wei C, Li H and Li Z. Effect of safflower yellow on platelet activating factor mediated platelet activation in patients with coronary heart disease. Bangladesh J Pharmacol 2012; 7: 140-144.

[323] Wang HF, Li XD, Chen YM, Yuan LB and Foye WO. Radiation-protective and platelet aggregation inhibitory effects of five traditional Chinese drugs and acetylsalicylic acid following high dose $\gamma$ irradiation. Journal of Ethnopharmacology 1991; 34: 215-219.

[324] Liwei G, Fei Y, Tianshan W, Guoxiang M and Yang P. Hemostatic effect of Flos Celosiae cristatae and its mechanism, 1996.

[325] Al-Snafi AE. The chemical constituents and pharmacological importance of Celosia cristata - A review. J of Pharm Biology 2015; 5(4): 254-261.

[326] Schumacher E, Vigh E, Molnár V, Kenyeres P, Fehér G, Késmárky G, Tóth K and Garai J. Thrombosis preventive potential of chicory coffee consumption: a clinical study. Phytother Res. 2011; 25(5):744-748.

[327] Al-Snafi AE. Medical importance of Cichorium intybus - A review. IOSR Journal of Pharmacy 2016; 6(3): 41-56.

[328] Riaz A, Khan RA, Mirza T, Mustansir T and Ahmed M. In vitro/ in vivo effect of Citrus limon (L. Burm. f.) juice on blood parameters, coagulation and anticoagulation factors in rabbits. Pak J Pharm Sci 2014;27(4):907-915.

[329] Al-Aghawani W, Al-Madi S and Al-Lahham A. The vasodilator effects of Convolvulus arvensis in rabbit isolated aortic rings. Arabic Journal of Pharmaceutical Sciences 2009; 9(3): 39-48.

[330] Al-Snafi AE. The chemical constituents and pharmacological effects of Convolvulus arvensis and Convolvulus scammonia- A review. IOSR Journal of Pharmacy 2016; 6(6): 64-75.

[331] Al-Aghawani W and Al-Madi S. Study the vasodilator effect at molecular level of Convolvulus arvensis in isolated aortic rings. Damascus Journal of health Sciences 2010; 26(1): 601-620.

[332] Nishio T, Okugawa H, Kato A, Hashimoto Y, Matsumoto K and Fujioka A. Effect of crocus (Crocus sativus L, Iridaceae) on blood coagulation and fibrinolysis. Shoyakugaku Zasshi 1987; 41: 271-276.

[333] Al-Snafi AE. The pharmacology of Crocus sativus- A review. IOSR Journal of Pharmacy 2016; 6(6): 838.

[334] Jessie SW and Krishnakantha TP. Inhibition of human platelet aggregation and membrane lipid peroxidation by food spice, saffron. Mol Cell Biochem 2005; 278(1-2):59-63.

[335] Srivastava KC. Extracts from two frequently consumed spices-cumin (Cuminum cyminum) and turmeric (Curcuma longa)- inhibit platelet aggregation and alter eicosanoid biosynthesis in human blood platelets. Prostaglandins Leukot Essent Fatty Acids 1989; 37(1):57-64.

[336] Zhou W, Abdurahman A, Umar A, Iskander G, Abdusalam E, Berké B, Bégaud B and Moore N. Effects of Cydonia oblonga Miller extracts on blood hemostasis, coagulation and fibrinolysis in mice, and experimental thrombosis in rats. J Ethnopharmacol 2014; 154(1):163-169.

[337] Hugar L and Ramesh H. Evaluation of hemostatic effect of Cynodon dactylon Pers in albino rats. Journal of Evolution of Medical and Dental Sciences 2014; 3(11): 2711-2713.

[338] Al-Snafi AE. Chemical constituents and pharmacological effects of Cynodon dactylon- A review. IOSR Journal of Pharmacy 2016; 6(7): 17-31.

[339] Seo EJ, Lee DU, Kwak JH, Lee SM, Kim YS and Jung YS. Antiplatelet effects of Cyperus rotundus and its component (+)-nootkatone. Journal of Ethnopharmacology 2011; 135: 48-54. 
[340] Xue JX, Jiang Y and Yan YQ. Effects of the combination of Astragalus membranaceus (Fisch.) Bge. (AM), tail of Angelica sinensis (Oliv.) Diels. (TAS), Cyperus rotundus L. (CR), Ligusticum chuanxiong Hort. (LC) and Paeonia veitchii Lynch (PV) on the hemorrheological changes in normal rats. Zhongguo Zhong Yao Za Zhi 1993; 18(10): 621-623.

[341] Al-Snafi AE. A review on Cyperus rotundus A potential medicinal plant. IOSR Journal Of Pharmacy 2016; 6(7): 32-48.

[342] Mekhfi H, El Haouari M, Legssyer A, Bnouham M, Aziz M, Atmani F, Remmal A and Ziyyat A. Platelet anti-aggregant property of some Moroccan medicinal plants. J Ethnopharmacol 2004;94(23):317-322.

[343] Al-Snafi AE. The pharmacology of Equisetum arvense- A review. IOSR Journal of Pharmacy 2017; 7(2): 31-42.

[344] Saluk-Juszczak J, Olas B, Pawlaczyk , Gancarz R, Wachowicz B. Effects of the extract from Conyza canadensis on human blood platelet aggregation. Gen Physiol Biophys. 2007; 26(2):150-152.

[345] Al-Snafi AE. Pharmacological and therapeutic importance of Erigeron canadensis (Syn: Conyza canadensis). Indo Am J P Sci 2017; 4(02): 248-256.

[346] Pawlaczyk I, Czerchawski L, Kuliczkowski W, Karolko B, Pilecki W, Witkiewicz W and Gancarz R. Anticoagulant and anti-platelet activity of polyphenolic-polysaccharide preparation isolated from the medicinal plant Erigeron canadensis L. Thrombosis Research 2011; 127(4): 328-340.

[347] Olas B, Saluk-Juszczak J and Pawlaczyk I. Antioxidant and antiaggregatory effects of an extract from Conyza canadensis on blood platelets in vitro. Platelets 2006; 17(6): 354-360. 